\title{
En nordslesvigsk præst. Carsten Petersen 1871-1943
}

\author{
Ved Carl Christian Jessen
}

En af det sønderjyske landsarkivs flittigste forskere i den første periode var pastor em. Carsten Petersen. Kirker og præstegårde og præster blev hentet frem fra de gamle dokumenter og levendegjort. Mindre kendt er nok den rolle, som Carsten Petersen selv spillede i kirkelivet, både i den tyske tid og efter Verdenskrigen og Genforeningen. Hans egne, desværre alt for kortfattede erindringer gengives her. Vi møder en mand, der kan skrive, fordi han har noget på hjerte.

\section{Indledning}

Carsten Petersen er i dag en røst fra fortiden. Men ved nærmere eftersyn opdager man i denne særprægede præstemands efterladte erindringer og $i$ hans produktion af kirkehistorie og opbyggelige tekster elementer, der har været betydningsfulde for grænselandets udvikling. Perioden 1871-1943, Petersens levetid, spænder over de faser, der afgørende har formet Slesvig frem til nutiden. De nationale, politiske og kirkelige modsætninger sled på den begavede og følsomme, men også noget kantede personlighed. Han havde svært ved at manøvrere i det offentlige rum i det omfang, som hans egne og andres forventninger berettigede ham til. I mellemkrigstiden ender han, efter sin præstetid i Sydslesvig og Magstrup, i Aabenraa, hvor han forsker og yder væsentlige, men ikke særligt systematiske bidrag til vor landsdels historie.

At »aflægge vidnesbyrd « er en nøgle til Petersens forfatterskab. Hovedværket Slesvigske Præster fra 1938 vil være et vidnesbyrd om den slesvigske gejstlighed som et »bindeled mellem det lille hjemland og den store verden «. Hvert kapitel indledes med et citat fra hans to væsentlige inspirationskilder, Søren Kierkegaard, der taler om det ubetingede, og Shakespeare, der i Hamlet skildrer ubeslutsomheden. Petersen genfinder i disse figurer sig selv, stående i grænselandets brænding og i skumsprøjtet fra modstridende bølger. 
Hans nærmeste åndsbeslægtede, folkeligt, kirkeligt og teologisk, er på sin vis biskoppen Theodor Kaftan, hvilket han nok selv ville påhøre med blandede følelser. Med modsatte nationale fortegn deltog de begge i kirkens og i grænselandets kampe, biskoppen i forreste række, Petersen mere iagttagende. Mod livsafslutningen var det svært at gøre regnskabet op. En vis bitterhed gjorde sig nok gældende, selvom den blev skubbet i baggrunden af de flittige studier og den sene anerkendelse. Petersen havde både bil og båd og levede et godt liv med rejser og kontakter langt ud over det hjemlige. Kirkens børne- og ungdomsarbejde blev længe ved at spille en rolle for ham, der ikke selv fik børn.

Carsten Petersen havde tysk uddannelse, fra Kiel, Berlin og Erlangen, inden han ved århundredskiftet fik embede ved den danske menighed i Flensborg, derefter i Brarup syd for Tønder og fra 1911-32 i Magstrup ved Haderslev. Teologisk vedblev han at være konservativ. Reformationen kalder han konsekvent for »kirkespaltningen « og øjner i det fjerne adskillelsens overvindelse. Med den unge præst $\mathrm{i}$ Brede, Jens Holdt, diskuterer han arvesynden; de var ikke enige om alting og begge til tider stejle i deres holdninger, herunder tolkningen af den slesvigske kirkehistorie. Nabopræsten i Vojens, den tilflyttede Aaholm, havde han mere kirkeligt fællesskab med. Og i grænselandsspørgsmål fastholder han stædigt, hvad man kan kalde den slesvigske holdning.

Vi giver ordet til ham selv. Erindringerne blev nedskrevet i 1940, en afskrift befinder sig i landsarkivet og en hos undertegnede, der i 1962 lånte det eksemplar, som befandt sig i Aaholms varetægt. Petersens samling af Søren Kierkegaard-udgivelser blev skænket til det nye fakultet i Aarhus, hvorfra rektor Johs. Munck takkede. Resten af hans bogsamling blev givet til Møgeltønder præstegård, hvor dets videre skæbne ikke er klarlagt.

Jeg har forsynet teksten med opklarende og supplerende noter. Fra Petersens hånd har hensigten været, at erindringerne skulle læses fortløbende og uforstyrret af kilder og dokumentation, derfor er noterne placeret efterfølgende. I Sønderjyske Årbøger 1961, s. 6-79, har Jens Holdt skrevet den mest udførlige biografiske fremstilling om Petersen, hvortil henvises. Her finder man en del stof og citater om hans litterære frembringelser samt billedstof (flere portrætter).

Den gengivne tekst er tilpasset nutidig retskrivning. 
Jakobsbrevet 4,14: Hvordan er Eders liv? I er jo en Damp, som er til syne en liden Tid, men derefter forsvinder.

\section{Barndom og skolegang}

I sydvesthjørnet af det dansktalende Slesvig eller Sønderjylland, dér hvor tre sprog, dansk, frisisk og tysk, mødes, ligger den lille, fattige og dog velkendte landsby Gallehus i Møgeltønder Sogn. Landskabet er ikke uden skønhed, mennesket ikke uden særpræg og egnen ikke uden historie. Mod syd lukker den store kirkeby med sin mægtige kirke i vestenden og Schackenborg Slot i østenden fuldstændig for blikket, så for dem, der boede i den nørre del af sognet, var den tyskfrisiske verden bag ved kirkebyen noget, man næsten aldrig fik at se. Men de fornemme linjer over trætoppene i den grevelige park og den gamle kirkes høje, kraftige tårn, der gennem århundreder troligt tog imod vestenvindens første anløb, indtegnede sig fra dag til dag i barnesindet og hører med til det første store, som mødte sanserne udefra. Øst for byen ligger de marker, som kaldes Galleagrene, hvor galgen i sin tid stod, da retterstedet for Møgeltønder birk formodentlig fandtes her. Af denne galge må byen formodentlig have fået sit navn. Længere mod øst er atter lukket for blikket, siden en stor skov er vokset op.

Kun under den store krig 1914-18 ragede den store luftskibshal, der var højere end Møgeltønder kirketårn, op over træerne og talte sit verdenshistoriske sprog til småfolk i omegnen. Imod vest er linjerne længere. Lidt utilsløret ligger i det fjerne havnebyen Højer med Vesterhavets eventyrverden uden for de høje diger. Ad den vej flyver vildgæssene i den lune sommeraften, mens hvide tåger skjuler engene ved Toghale. Nord for byen ligger Lindskovmølle, vind- og vandmølle med smukke storladne omrids over den lille sø. Længere borte glider øjet uden nogen hindring frem over et hedelandskab med utallige tilgroede hjulspor; hvor engang var alfarvej fra Tønder til Ribe, ved hvilken vej - i den nordligste del af Gallehus by - de to guldhorn fandtes. Ude i synsranden stiger Visby kirkes ejendommelige tårn frem.

Byen er i sig selv ringe og er kommet ind i historien ved den omtalte galge og de omtalte guldhorn. Ingen har nogensinde tænkt, at guldskatten har tilhørt nogen i byen eller skulle være gjort her. Men 


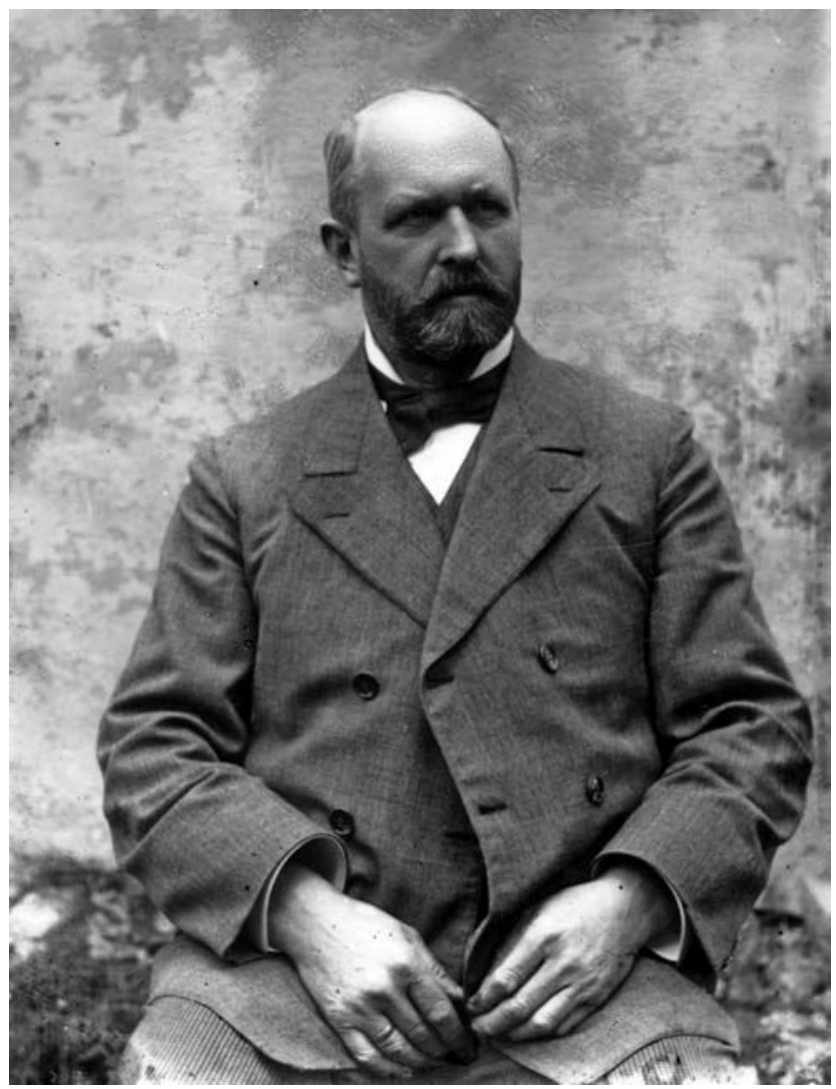

Carsten Jensen Petersen, født i Gallehus, Møgeltønder Sogn, den 1. juni 1871, søn af snedker Peter Andreas Petersen og hustru Anna Kirstine født Jensen. Gift den 21. juli 1903 med Emma Anna Catharina (Katrine) Petersen, født den 29. maj 1870 i Haderslev. CP død i Aabenraa den 24. februar 1943. Dette portræt må formodes at være fra ca. 1918, hvor CP var sognepræst i Magstrup. Foto: Museum Sønderjylland - ISL.

det er vel også stort, at den har været gemt her gennem mange hundrede år. Fattige og ærlige hænder løftede den af jorden og skænkede den til moder Danmark, der ikke formåede at vogte skatten så vel, som bondens ager i Gallehus havde gjort. Men sagn og fortælling går fra slægt til slægt om disse og andre fund og hører med til det, der i ny og næ fylder gamle og unge i byen med stolte anelser.

Thi folket dér er af en egen slags. Ikke som dem i Møgeltønder, ej heller som dem i Toghale, men lige akkurat som dem i Gallehus. Små- 
folk var de for 50 år siden næsten alle sammen. Der var ingen standsforskel. Men intet ville de hellere end at være noget for sig. Hus ved hus lå dengang langs med gaden i en regelret trekant med udløbere $i$ alle hjørner, i hvert hus en ko eller to eller slet ingen. Men tro ikke, at nogen kendte sig fattig eller trængende. Nej, nej, tiggere boede der andre steder, ikke i Gallehus. Hvad værre var, også over for Gud var man stadig noget for sig. I kirken kom man sjældent, og der var et tidsrum, hvor det ene selvmord fulgte det andet. Dog var der, det forstår jeg nu, et gammelt tungsind $\mathrm{i}$ den gamle by.

Midt i byen ligger endnu et teglhængt hus, som i sin tid tilhørte en tændstiksfabrikant. Der var nemlig foretagsomme mennesker iblandt byens og egnens folk. Engang i fordums dage dyrkede man havefrugter og solgte dem i Tønder, pigerne kniplede rimeligvis i alle hjem. Men engang hittede altså en mand på at fremstille futtende træpinde. Det endte desværre med, at det hele, så vidt jeg ved, futtede af en dag. Men et nyt hus blev bygget, og dette hus købtes senere af min fader. Slægten var da ikke fremmed i byen, men havde boet der i et par slægtled. Ellers stammede den fra Jejsing i Hostrup Sogn. Den første vi kender i lige linje tilbage hed Peter og levede i første halvdel af det 18. årh. Den næste, hans søn, var Andreas Petersen, der var indsidder, d.e. en mand uden jord, i Jejsing. Hans søn Peter Andresen giftede sig med en pige i Gallehus og overtog med hende hendes fædrenehjem, men endte, gift 2. gang, på Møgeltønder fattiggård. Han var ellers vognmand og gik under navnet Per Tved. Hjemmet i Gallehus lå og ligger endnu lige uden for stedet, hvor guldhornene fandtes. En af Per Tveds sønner var Andreas Petersen, som lærte bygge- og snedkerhåndværket. Han ejede et hus med en del jord længere mod syd i byen, hvor vejen bøjer af mod kroen. Den næstældste af hans mange sønner var min far Peter Andresen Petersen, der havde lært håndværket hjemme hos sin fader.

Andreas Petersen, min bedstefader, var en anset håndværker, der også søgtes af borgerne i Tønder. Mange gårde i omegnen har han og hans sønner bygget. En mand har fortalt mig, at da en gård i Østerby blev rejst, stod mesteren på muren og holdt rejsetalen med tre sønner ved sin side. Af disse sønner blev to selvstændige mestre i Gallehus, idet den yngste af dem overtog fædrenehjemmet. Den anden derimod, min fader, fik sit bosted længere mod syd i byen. Da far drog ind i tændstikfabrikantens hus, som han selv havde været med til at bygge, havde han med sig sin unge hustru, en bondedatter fra Togha- 
le. Hendes navn var Ane Kristine Jensen, hendes far var en fæstebonde under Schackenborg hovedgårdstakst, og gården kaldes i gamle dokumenter Frankes stævn. I mindst et par hundrede år har den tilhørt slægten. Da der ingen sønner var i min moders hjem, overtog en svigersøn halvparten af gården i Toghale, mens fader fik den part af jordene, som lå nord for Gallehus (på Toghalemark). Som følge heraf begyndte fader et større byggeri. Til sidst dannede den en lukket lille gård, rejst af fader selv.

I denne venlige gård, som med sit røde tegltag og sine lyse mure synede langt ud i omegnen, er alle mine søskende og jeg kommet til verden. Vi kunne have været ni, men fire døde som små.

I åndelig henseende ved jeg ikke at nævne noget som helst, der kan have sat præg på de to slægter. Om der har været nogen iblandt dem, som regnede sig til de stille i landet, hvem ved det? Danske var de alle, og et gammel Dannebrog fra før 1864 findes endnu i slægtens eje. Faders slægt har taget små jævne skridt opad. Farfaders fader var møllerkarl og boede i et lille hus i nordenden af byen, en tid også vognmand, men endte dog på fattiggården; hans søn blev håndværksmester og boede i byens centrum; hans ældste søn blev gårdmand og kommuneforstander og boede i byens centrum; hans ældste søn kom til at sidde i en af landets smukke præstegårde. Andre i slægten er velstillede købmænd eller gårdmænd, sognerådsformænd eller sognefogeder etc. Mærkeligt få af den danske gren gik den studerende vej.

Fader var den livlige, hurtige og kvikke natur, der altid var fuld af interesse for livets praktiske side og drøftede gerne dagens sysler og sager. På hans side har vi mange muntre håndværkere og købmænd. Når de mødtes til familie og slægtsstævne, lo og sprang de som børn. Moder var den tænkende og indadvendte, den dybe nynnende, i sig selv ligevægtige, kloge og uafhængige natur. På hendes side er bønder, gård ved gård, men sælsomt nok også udvandrere. Moder så op til sin mand, og fader så måske endnu mere op til sin hustru. Midt i livets møje var de to lykkelige mennesker. Når moder i de sene år på grund af sin svaghed havde svært ved at stritte mod blæsten undervejs hjem fra et lille aftengilde i byen, kunne fader tage hende på sine arme og bære hende resten af vejen.

Deres første barn, en søn, døde snart efter fødslen. Den næste er jeg. Den 1. juni 1871 er min fødselsdag. Ingen har fortalt mig noget nærmere om denne begivenhed, eller hvordan jeg artede mig i denne 
min første tid. De første store erindringer, jeg har bevaret, knytter sig til byggearbejdet ved vort hjem og til en sygdom, som hjemsøgte dette hjem. Begge forældre og et par andre voksne personer fik tyfus, og en snedkersvend døde heraf. Vi børn undslap derved, at vi udsattes til slægtninge og naboer. På den måde kom jeg til at opholde mig nogle uger eller måneder i min moders hjem i Toghale. Kun nogle få småtræk har sat sig fast i min erindring fra de dage. Efter at den hårde sygdom var overstået, samledes den lille børneflok - vi var tre - igen, og der var nyt solskin over hjemmet.

Først da jeg skulle begynde min læsning på skolen i Haderslev, blev fader optaget som preussisk undersåt, noget der naturligvis måtte ske, for at jeg kunne betræde embedsvejen. Min første skolegang var i Toghale, hvor der virkede en gammel lærer, som havde undervist både mine forældre og alle deres søskende, nu var hans tid snart omme. Om ham selv ved jeg ikke stort at sige ud over det, at han var en ejendommelig personlighed med et par øjne, der stundom forekom at kunne se både udenom og tværs igennem. Men han havde to sønner, som ikke er ubekendte i Slesvigs historie, navnlig på vesteregnen. Den ene var Jens Jessen, senere redaktør af Flensborg Avis, om hvem jeg har skrevet i min bog om Slesvigske Præster, den anden var degn og skolelærer Peter Jessen, sidst i Daler, vort nabosogn. Skønt den gamle kom fra Toftlundegnen, blev slægten præget af enklaverne og vestkysten. Begge brødre har været med til at give disse egne den smukke plads i vort lands historie, som de stadig indtager. Da Jens Jessen stod på højden af sit virke, udtalte han engang til mig, at det er mærkværdigt at se, hvilken evne vestboen havde til at mestre det danske sprog. Det var også i de egne H.A. Brorson groede op. Efter Jessen kom en yngre mand til Toghale skole, og han blev min egentlige lærer. Det var omkring 1880. Da udfoldede det tyske styre sig fra år til år. Endnu var dog det danske sprog ikke skubbet til side for det fremmede. Den store sprogforordning, som gjorde tysk til næsten udelukkende undervisningssprog $i$ alle fag (undtagen nogle frivillige danske religionstimer), kom først 1888, da jeg havde forladt folkeskolen.

Preussernes historie måtte vi lære fra slaget i Teutoburgerwald til Sedan. Årstallene kunne vi på fingrene, dem vartedes der op med, når den preussiske skoleinspektør kom. Ellers når vi var alene, kunne læreren give os et lille indblik i Danmarks historie, og om den brandenborgske kunne han ved lejlighed udtale sig lidt kritisk. Han lod os forstå, at der var pyntet på den i bogen. Den var børstet, sagde han. 
Omkring ved mit tolvte år tog mit liv den vending, som blev afgørende for de kommende dage. Ved en bispevisitats i Møgeltønder kirke kom jeg med mine svar til at vække biskop Godts opmærksomhed. ${ }^{1}$ Han, der selv var udgået fra et bondehjem og havde et godt øje for børn, spurgte efter gudstjenesten ved samværet i præstegården, om den dreng skulle studere, hvortil min lærer svarede: Forældrene har vel ej råd dertil. Der blev blandt de kyndige talt mere om den sag, og nogle dage senere besøgte sognepræsten H.S. Prahl ${ }^{2}$ mine forældre og overtalte dem til at lade mig betræde den akademiske løbebane. Jeg siger overtalede, fordi det den dag i dag er mig tvivlsomt, om det var den af Gud bestemte vej.

Hvad, jeg gik ind til, var foreløbig grufuldt. Den privatundervisning, jeg fik i hjemmet i tre år, blev en pine for min sjæl, som jeg aldrig har glemt. Nu så længe bagefter, når jeg ser tilbage på dette afsnit af mit liv, kommer der op i mig en blandet følelse af beundring og foragt. Jeg må beundre den tålmodighed, hvormed jeg holdt pinen ud. Noget af en fatalist har jeg nok altid været. Ikke en eneste tåre har jeg grædt under den meningsløse og hårdhjertede opdragervisdom, jeg blev offer for, ikke en eneste gang erindrer jeg at have udtalt mig om, hvad der i disse år bundfældede sig i mit indesluttede og let pirrelige og let sårede sind. Men med uvilje og foragt må jeg se tilbage på den ubeslutsomhed og mangel på vilje, hvorved jeg fandt mig i alt i stedet for at bryde overtværs.

Begge dele er blevet hængende ved mig. Jeg har endnu en stor evne til at finde mig i min skæbne, men en ringe kraft til at vove mig ud på nye veje. Jeg har aldrig holdt af at komme for sent, når der drejede sig om klokkeslæt, men jeg er ofte kommet for sent, når det drejede sig om lejligheden. Skønt jeg har sejret i væddeløb i min ungdom og så nogenlunde bestået mine eksaminer, så har jeg dog hverken været en væddeløber eller et eksamensmenneske. Alt, hvad jeg skal løbe med andre om, taber sin værdi for mig, jeg giver afkald derpå uden den ringeste smerte. Det træffer i høj grad noget væsentligt i min karakter og udvikling, når jeg anfører det fra et vist område velkendte ord: uden for konkurrence. Det blev sognepræsten som uheldigvis - kom til at give mig de fleste undervisningstimer. I timevis var jeg overladt til mig selv, for så ved formiddagens afslutning at modtage en mængde skænd, hvorefter jeg gik hjem, fuld af ulyst til at lære lektie til den næste dag.

De kundskaber, jeg ellers havde brug for, måtte jeg hente mange 
steder. I Toghale skole, hos andenlæreren i Møgeltønder, hos godsinspektøren på Schackenborg og en nurse sammesteds. Kun en af mine lærere vandt noget mere end min agtelse og taknemlighed, den nu for længst afdøde C. Jensen fra Genner, sidst i Årslev, Hjordkær Sogn. Alle gjorde de deres flid med mig, og et år efter min konfirmation kunne jeg optages på latinskolen. Fire klasser var sprunget over.

\section{Skolegang i Haderslev}

Det blev Haderslev lærde skole, som den hed indtil 1864, eller gymnasiet, som den hed i den tyske tid, jeg kom til at besøge i seks år 1887-1893. ${ }^{3}$ Skolens rektor (Direktor) var den gamle, patriarkalsk anlagte Jessen ${ }^{4}$. Han var en god tysker, men gav selv timer i dansk og roste sig af at have lært sproget hos Molbech. Af lærere var der en del hjemmefødte, som ligeledes kunne dansk, senere kom historikeren A. Sach til, som kun kendte sproget gennem sine studier og talte det dårligt.

Den gamle rektor har jeg beholdt i venlig erindring. Var han en slesvig-holstener, så har jeg tilgivet ham det. Endnu står han klart for mit øje, således som han efter det store frikvarter plejede at postere sig uden for lærerværelsets dør, lige foran hovedtrappen. Der stod han dag for dag, som en pædagogisk feltherre, der mønstrede ungdomsflokken, mens den stormede op ad trappen for at dele sig i to flokke lige under de to gamle, stirrende øjne. Endnu ser jeg ham i klasseværelset gå op og ned ad midtergangen og stundom standse helt i nærheden af mig eller en anden elev og, mens han med den lange blyant slog nogle små slag i bordet, indprentede nogle væsentlige punkter, som skulle huskes, f.eks. den sætning at »kristendom er ikke lære, men liv«. Åbenbart tænkte den gamle sig at opretholde orden og god tone ved at vise en personlig værdighed alle vegne, hvor han gik og stod, til tider en vis utilnærmelighed, også et ironisk smil. Om der ved lejlighed løb lidt pedanteri med, tør jeg ikke sige. Der havde været en tid, hvor adskillige begavede unge mænd måtte forlade skolen på grund af drik, og i mine dage var der netop også på dette punkt en alt for stor frihed. Først under efterfølgeren blev der brugt andre midler. Der skete det, at vi en af de første dage samledes i skolens aula med en hemmelighedsfuld anende rædsel for at få forelæst skolelovene, noget som i den gamle rektors tid aldrig var blevet nævnt. 


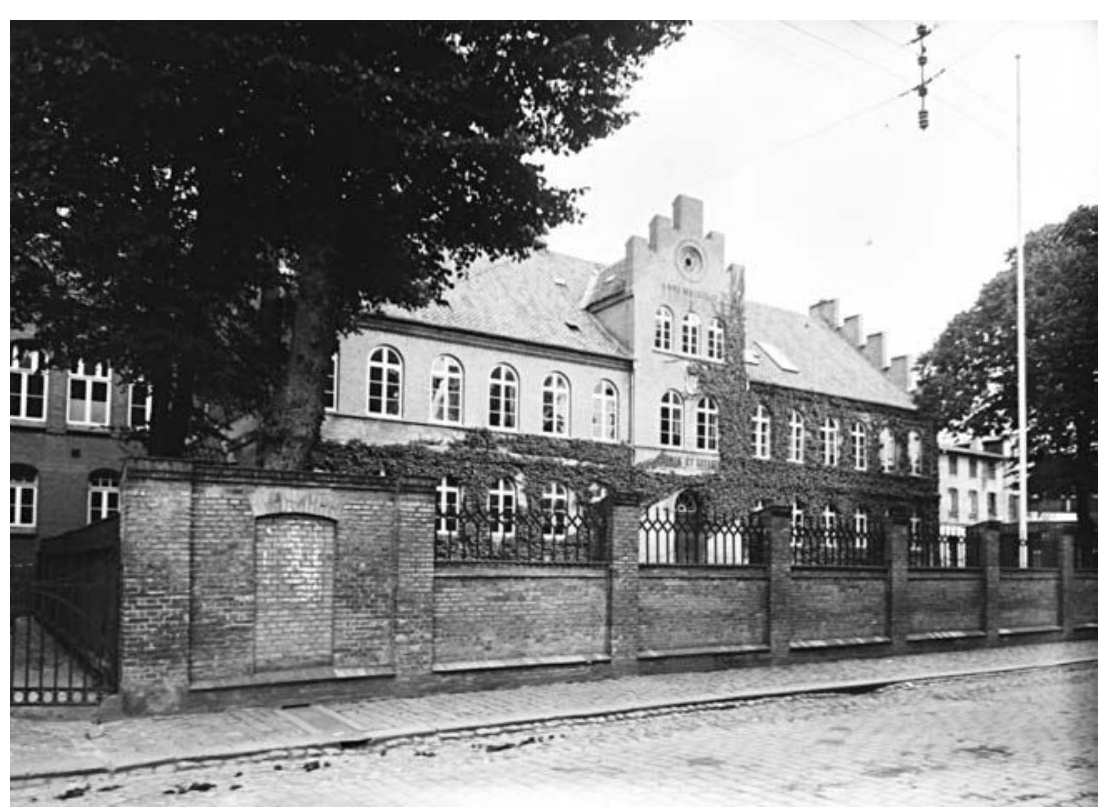

Haderslev lærde skole, Katedralskolen, senere billede. Foto: Museum SønderjyllandISL.

Jeg tror, at rektor så mildt til landsbydrengen, da han mødte i klassen og satte sig på den nederste plads, uindviet som han var i skolekneb, knap nok fortrolig med det tyske sprog og i alle måder præget, som han var af det fjerne flade landskab og de fattige forhold. Den gamle kendte intet til elskværdigheder, hverken inden eller uden for skolen, men når han mødte mig på gaden, og jeg tog hatten af for ham med al den respekt, som sådan en naturplante måtte have for en almægtig skolebestyrer, så kunne han svare med et: Guten Tag Petersen! Og den lykke syntes jeg var stor. Hvad den mand kom til at betyde for min person, kan jeg nu ikke gøre rede for. Men han er en af figurerne på mit livs scene, som optræder nu og da, slår til lyd med blyanten og docerer: Kristendommen er ikke lære, men liv - og præsten bøjer sig for den gamle filosof.

Den, der indgød mig en daglig angst, var klassens ordinarius, en slægtning til den bekendte digter Geibel. Han var morfinist og aldeles uden al sund metode i sin undervisning. Først senere forstod jeg, at manden skulle tages fra den komiske side, men da havde jeg haft 
angsten. Både den sidstnævnte og en gammel professor blev mere en spillebold for eleverne. Utallige er de historier, der kunne fortælles om dem. Omsider forsvandt de, ligesom den gamle rektor, der blev træt undertiden.

Den nye leder af den lærde skole var en mand sydfra. Ostendorf ${ }^{5}$ hed han og har bevaret sig et godt navn blandt de fleste af eleverne. Naturligvis var han også en tysker, men alt småligt lå ham fuldstændig fjernt og var hans væsen imod. Efter at han var kommet til Haderslev, gav han sig til at lære dansk. Hvor langt han nåede dermed, ved jeg ikke, han blev senere forflyttet til Schlesien. Hele skolelivet gennemgik under ham så at sige en fornyelse. Hans egen klasse (prima) blev forsynet med løse borde og stole og trækgardiner for vinduerne. Under undervisningen blev det stillet os frit at tage plads, hvor vi ville, f.eks. til afveksling stående ved vinduet. Vi skulle i det hele taget behandles som voksne, forstandige mennesker. Det har sommetider været mig påfaldende ved tyske universiteter, at det dér tilsyneladende gik mere skolemæssigt til end på vor nordlige latinskole.

Påfaldende var det, at rektor snart efter indførelsen af de strenge skolelove selv erklærede, at sådanne love ikke var for ikke at overtrædes, men for at de ikke måtte overtrædes for meget. Og det som gjorde, at han blev så frisindet og skænkede sine elever en stadigt voksende tillid, var efter hans eget udsagn det, at han hos den nordslesvigske ungdom havde mødt en så åben karakter og et så stort mål af redelighed over for læreren, som han ikke havde ventet og vel næppe heller kendt andetstedsfra. Da var det gået op for ham, at med militæriske eller anstaltsmæssige opdragelsesmetoder skulle denne ungdom ikke dannes. Også uden for skolen ville han have denne ungdom i sin hånd, dog $\mathrm{i}$ frihed. Medens det var forbudt at gå med en cigar på gaden, kunne det godt ved visse lejligheder tillades at holde et regelret sold efter tysk studenterskik. Rektor bød da: Slut kl. 12. Dette overholdtes på den måde, at præses ved midnat erklærede det officielle sold forbi: die offizielle Kneipe ex. Hvorefter man roligt fortsatte, så længe man lystede. Således overtrådtes skolelovene, men ikke for meget.

I alle de år jeg tilbragte i Haderslev, var der ingen strid eller tvang m.h.t. sprog eller nationalitet blandt eleverne. Næsten halvdelen af mine kammerater var dansktalende og brugte ganske uhindret deres modersmål. Mange af de tysktalende borgerbørn fra Haderslev kunne også godt forstå og tale sproget, og de gjorde sig ofte en fornøjelse at 
snakke sønderjysk med os andre. Skriftdansk derimod hørtes ikke i vor kreds. I begyndelsen var der endnu et par danske sprogtimer om ugen, men de blev, efter at rektor Jessen var fratrådt, gjort til frivillige timer og fandt da kun ringe tilslutning, nærmest kun af nogle dansksindede elever.

Under mit ophold i Haderslev boede jeg hos en lærer ved folkeskolen, hvis datter blev min senere hustru. ${ }^{6}$

\section{Studietiden 1893-99}

Påsken 1893 forlod jeg skolen for at begynde det teologiske studium. Samme tid, skærtorsdag aften, døde min moder. Med hende mistede jeg alt, hvad et menneske kan miste og berøves ved en andens død. Mange ting, som møder os her i livet, får vi en forklaring på, når år er gået. Dette har jeg aldrig lært at forstå. Hun sov stille hen uden en klage, uden et farvel, ja uden så meget som et afskedsblik, træt og afkræftet, som en, der begærer at hvile og intet andet. Små folk i byen kom og så hende, da hun var død og lagde en fattig, selvbundet krans på hendes kiste. De vidste, hun havde været deres ven og hjælper, skønt hun havde kun lidet at hjælpe med. Men mig har den efterfølgende tid mere og mere indtil dette øjeblik lært at forstå, at alt det bedste og dybeste jeg ejer, har jeg arvet fra denne kvinde. Et år derefter blev hendes søster os en god stedmoder.

Af sparsommelighed valgte jeg Kiel som mit første universitet. Her var der håb om at komme til at nyde nogle stipendier, og rejsen var let at overkomme. Nogle slægtninge på mødrene side besøgte Ribe skole sammen med en del andre unge mænd fra sognet, og derfra gik de til Københavns Universitet. På hele deres studievej har de nydt godt af de til Slesvig henlagte legater o.s.v. Min fader så fra begyndelsen klart i denne sag og erklærede, at hans søn skulle blive i landet. Den vej, jeg derved kom til at gå, var ikke uden vanskeligheder, men jeg har mange gange takket ham for denne afgørelse. Det blev på den måde min lod at dele godt og ondt med det folk, som måtte kæmpe sin kamp mod Danmarks gamle fjende gennem et halvt århundrede.

Universitetet i Kiel var, da jeg blev indskrevet i dets liste, ikke mere slesvig-holstenismens arnested som i forrige tider, simpelthen af den grund, at denne politik - som en modsætning til både Tyskland og Danmark - havde udspillet sin rolle. De teologiske lærere var næsten 
alle indvandrede tyske videnskabsmænd, der fra deres kateder aldrig rørte ved et politisk spørgsmål. Ingen af dem kom til at betyde noget for mig. Jeg mærkede vel, at deres visdom dog i grunden kom fra en fremmed verden og i et fremmed klædebon. Det var ikke Danmarks og Nordens kirke og ikke nordisk tale eller tænkning, som mødte mig. Først længe bagefter har jeg fået et begreb om, hvilken hindring det har været for mig - og formodentlig for andre med - at modtage hele min åndelige dannelse og udvikling i et fremmed sprog og omgivet af et fuldstændig fremmed åndsliv. Jeg tvivler ikke om, at de folk har nemmet det bedst, som i større eller mindre grad satte deres eget til side og blev fremmede for deres eget folk. Men der var altså ingen anden vej.

Når jeg siger, at af de akademiske lærere i Kiel fik ingen betydning for min indre udvikling, hænger det nok sammen med, at jeg som adskillige unge studenter brugte mine første semestre til meget andet, end hvad man just kan kalde studeringer. Jeg var en kunstelsker og har tilbragt megen tid i det akademiske kunstkabinet og i læseværelset, ligesom jeg besøgte kunstsamlinger, teater og udstillinger og med stor forkærlighed hengav mig til arkitekturen og dens historie, navnlig da til den så storslåede og så alt overragende kirkearkitektur. En sommerdag opførte vi også et skuespil, nemlig det store Gustav Adolf festspil af Otto Devrian, med ham selv i kongerollen, endda for meget høje herskaber. Ellers dansede vi ved lejligheder og sad ved ølbordet i vore foreninger. Under alt dette stod teologien ofte i baggrunden, og det var ikke helt uden indre sammenhæng, at da jeg senere for anden gang vendte tilbage til Kiels Universitet, genkendte fægtemesteren mig, men professorerne ikke.

Hver middag kl. 12 rungede et kanonskud hen over fjorden og fik vinduerne i universitetsbygningen til at klirre. Dette skud angav ikke blot tiden, men gav også til kende, at den kejserlige flåde, hvorfra skuddet kom, var toneangivende i byen eller dog mente at være det. Alle de kejserlige besøg gjaldt naturligvis kun flåden. Imellem studenterne og søofficererne eller kadetterne på søakademiet var der kun ringe og tilfældig forbindelse. Stridigheder f.eks. i form af dueller var kun undtagelser. Enhver skøttede sig.

Det gamle Kieler-borgerskab sympatiserede sikkert mest med studenterne, men tusinder af arbejdere var knyttet til det kejserlige værft. Enkelte tildragelser om bord på de store skibe kunne sætte mange sind i bevægelse. Straks i mit første semester var jeg tilskuer ved 
en stor begravelse. Så vidt jeg mindes, omkom ca. 40 mand ved en kedeleksplosion, da et nyt skib var på prøvefart. De begravedes i en fælles grav. Kejseren begik ved denne lejlighed en af sine mange taktløsheder. I stedet for selv at komme til stede sendte han et telegram, som udtalte den høje herres medfølelse, men sluttede med ordene: Im übrigen Volldampf voraus! Hvilke ord vakte bitterhed i mange sind.

Fra det provinsielle akademi med de mere hjemlige forhold blandt de mange kendte kammerater drog jeg - efter $1 \frac{1}{2} 2$ års ophold - til Berlin. Et beskedent stipendium fra Tønder var lovet mig, og nogle undervisningstimer ville vel hjælpe lidt på budgettet. Det var nu meningen at få noget bestilt. Derfor fik jeg mig indlogeret i et stift, hvor man boede nogenlunde billigt, og hvor jeg havde tænkt mig at komme under stimulerende indflydelse og lidt kontrol. Huset hed Melanchton-stift og havde plads til en 20-30 studenter af alle fakulteter, som levede under tilsyn af en senior og under overtilsyn af en hofpræst. En præsteenke var bestyrerinde. Allerede ved den første indtræden i huset blev jeg skuffet. Enhver beboer fik uden videre udleveret en nøgle til gadedøren. Samlivet begyndte med et regulært sold. Hvad der var af husorden, indskrænkede sig til det rent udvortes. Af åndelig tugt og klosterregler var der intet.

Så forsøgte jeg selv at lægge en arbejdsplan. Forelæsningerne ved universitetet vandt min interesse, hvad de ikke havde gjort i Kiel. Professor Harnack ${ }^{7}$ læste sin kirkehistorie (oldkirken). Jeg mindes endnu det indtryk, det gjorde på mig, da han på sin legende måde, halvvejs siddende på selve katederet med et dinglende ben foran og et penneskaft i hånden, udtalte som det samlede historiske resultat af Jesu liv: Alt, hvad vi ved om Jesus, er dette, at han har levet og lært, at han er død, og at hans disciple har troet at se ham igen. Opstandelsens under var der ingen plads for i historien. For resten vidste jeg ikke dengang, med hvilke midler jeg skulle undersøge pålideligheden i denne historiegranskning. Først langt senere har jeg forstået, at også rent historisk set - uden at kalde på den religiøse indstilling - er sagen ikke så ligetil. Enhver alvorlig gransker vil have meget svært ved at komme uden om de vidnesbyrd, som foreligger til bekræftelse af dette og andre undere i Jesu liv.

En modsætning til Harnack i sin fremtræden på katederet var Julius $\mathrm{Kaftan}^{8}$. Hans foredrag var tørt, ofte dikterende og på grund af manglende tænder ofte hvislende, hvilket sidste endnu forøgedes ved 
den skarpe s-lyd, som han havde arvet fra sin hjemegn, Løjt Sogn. Han var en dogmatiker af den ritschl'ske skole, men byggede sit eget system. Det forekom mig, at han brugte den lutherske ortodoksis udtryksmåder, mens der dog lagdes noget nyt deri i et sådant omfang, at sandheden og redeligheden vanskeligt kunne være tjent dermed. Her har den mere personlige side af striden mellem højre og venstre i tysk teologi haft sin egentlige brod, idet man fra venstre bebrejdede de gamle, at man lærte en dogmatik, som intet moderne, sandhedss $\varnothing$ gende menneske kunne bøje sig for, mens man fra højre bebrejdede den nye teologi, at man lærte noget ganske nyt, en moderne subjektivisme, ja en helt ny religion uden dog at løse sig fra den gamle former. I personlig berøring kom jeg ikke med nogen af disse lærde, men Kaftans forelæsning hjalp mig naturligvis til at få større klarhed over den liberale teologi. Af lærere uden for det teologiske område skal jeg nævne Heinr. v. Treitschke. Hans forelæsning om stat og kirke samlede en stor skare tilhørere i husets største auditorium. Kraftig og bred, som han stod der, var hans tale også stærk og krydret med vittighedens salt. Han var meget tunghør og lagde derfor hverken mærke til klokkens slag eller forsamlingens tilråb. Man gav ham derfor heller ikke ved indgangen den sædvanlige hilsen med trampen eller håndklap.

Lige over for universitetsbygningen (Unter den Linden) lå Kaiser Wilhelm I's palæ, i hvis ene fløj det kgl. bibliotek opbevaredes. Her satte jeg mig en dag til rette med pen og papir for at gennemgå Matthæus-evangeliet. Jeg nåede ikke til ende med det.

Byen Berlin tog mig mere og mere. Dens raske gadeliv med stadigt nye indtryk, dens alsidighed og brogethed, dens storhed både i det enkelte og i helhedsbilledet, dens gemytlige selskabsliv, hele den berlinske oprindelighed, ja selve dette at finde en stor sum af ligefrem og ukunstlet menneskelighed midt $\mathrm{i}$ en verdensby, fængslede mig meget. Og når jeg nu efter så mange år ser tilbage på den vinter, jeg studerede i den tyske hovedstad, og spørger mig selv, hvad dette mit første møde med en residens- og verdensby har haft af betydning for mit senere liv, så tror jeg det betød mere, end jeg da kunne blive mig bevidst. Det var ikke blot dette, at jeg oplevede, hvad enhver ung mand vil komme til at opleve på sin første store rejse ud i verden: at målestokken bliver forandret. Mennesket er alle tings mål, et elastisk mål der udvider eller indsnævrer sig, efter som øjet rækker langt eller kort. Berlin løftede mig en stund op i en art residensatmosfære, op 
over provinsen og spidsborgermiljøet. Da jeg rejste hjem igen og fra Lombardbroen i Hamborg så ned over Alsterbassinet, fandt den gamle landsdelsby ingen nåde for mine unge øjne. Jeg havde vandret dagligt Unter den Linden og over Lustgarten, jeg havde i nationalgalleriet stået så mangen gang over for Böcklin, Menzel, Kantbach, Rembrandt - jeg havde stået på Louisebro og set op ad den $3 / 4$ mil lange Friedrichsstrasse med dens menneskevrimmel, mens de store fjerntog rullede frem og tilbage til Aleksanderpladsen. Jeg kom fra hoffets, diplomatiets og intelligensens by, Tysklands unge stærke hjerte, fra det sted, hvor samfærdslens kongeveje i Nordeuropa mødes. Hamborg - hvad er Hamborg? Jomfrusti? Elbe? Sct. Pauli? En røgindhyllet kaffeforretning, ikke værd at se på.

Men jeg fik noget sundere og bedre med mig hjem end denne overanstrengte målestok, som dog snart rettede sig. Jeg havde oplevet, hvor mærkværdigt let og hurtigt en landsbydreng fra Nordslesvig fandt indgang blandt storbyens mennesker. Det var en kold efterårsmorgen, da jeg med min studenterbylt i hånden traskede første gang gennem Brandenburger Tor og på mit første spørgsmål efter en bestemt gade af en bagerdreng fik det godt berlinske, men lidt opmuntrende svar: Det wees ich nich. Hvor langt anderledes var det, da jeg en nat i marts stod på toget på Lehste banegård for at drage hjem igen. Ene var jeg da, men jeg følte noget i denne by, som var blevet mit og trods afskeden fulgte mig. Den store fremmede verden havde skænket mig minder, som jeg ville gemme længe på. Noget lignende har mødt mig senere på andre steder. Og jeg, som ellers har så svært ved at komme i samtale med et menneske, har gennem disse erfaringer vundet et stykke tro på, at det menneskelige findes alle vegne, ikke mindst i de frygtede storbyer.

I foråret 1895 tog jeg vejen sydpå. Vandretrangen, som jeg endnu føler hvert forår, var for stærk. Hvad det end måtte koste, så måtte og skulle jeg have bjergene at se. Efter en lang rejse, som sædvanligt på fjerde jernbaneklasse, landede jeg i den lille bayerske by Erlangen. ${ }^{9}$ Det var helt imod min forventning bitterlig koldt, og værtinden måtte af ren medlidenhed lægge et par stykker træ i kakkelovnen. Senere hen fik vi 30-40 graders varme.

Universitetets stolthed, teologen Frank, levede ikke mere. Jeg måtte nøjes med mænd som Zahn og Seeberg. Privat gennemarbejdede jeg med megen flid profeten Esajas. I det hele førte jeg et meget stille liv uden nogen tilslutning hverken til professorer, studenter eller byens 
befolkning. Men fra tid til anden foretog jeg naturligvis en udflugt $\mathrm{i}$ omegnen. Flere gange gjorde jeg en søndagsspadseretur til Nürnberg. En vandring på flere dage førte mig gennem fränkische Schweitz til Bayreuth; Fichtelgebirge nåede jeg ikke.

Det mærkeligste og interessanteste var en fodrejse til bispebyen Bamberg. Nürnberg er evangelisk, men Bamberg er et af den katolske kirkes gamle knudepunkter i Sydtyskland. Jeg vandrede natten igennem for at kunne nå mit mål i den tidlige morgenstund. Det var nemlig Kristi Legemsfest, en af den katolske kirkes største højtider. Men da jeg kl. fem-seks om morgenen vandrede ind ad byens gader, var kirkerne allerede fyldt med røgelse, bestrøede med fint grønt, og ud og ind gennem dørene færdedes festklædte mennesker af alle slags og fra alle egne af landet. Mange havde jeg allerede kl. fire mødt uden for byen. Jeg havde den dristighed at besøge den prægtige domkirke med dens rige historie og arkitektur, mens man beredte sig derinde til den store procession gennem byen. Det var første gang i mit liv, at jeg mødte det væld af gammel kristenkultur, bygget op gennem tusinde år, som en domkirke af rang frembyder. Gemt bag en pille var jeg en tavs tilskuer, mens processionens hoved dannedes i koret. Da skarerne i en uendelig række bevægede sig gennem gaderne, stod jeg derude i den lyse sommerdag og lod det brogede billede glide forbi mit øje: bisper, prælater og præster. Sakramentet (eller Guds moder) under baldakinen omgivet af bayerske husarer, munke og nonner, hver i sin ordensdragt, skoler og foreninger og en utallig vrimmel af mennesker klædt i maleriske dragter, alt sammen båret og besjælet af den til højtiden svarende alvor. Jeg har aldrig haft noget til overs for processioner, mennesket bliver let, mens det spanker frem i rad og række, til en pjanket dukke. Men en skare af stille, fremadskridende mænd og kvinder, lig en pilgrimsmasse dragende ud ad domkirkens porte, man ved ikke hvorhen, må fængsle en hvilken som helst tilskuer, også den fremmede, som intet kender og intet forstår. Det har vel været et syn som dette, der har været med til at vække en endnu utilfredsstillet længsel efter at lære den kirke lidt nærmere at kende, som formår at udfolde et sådant mål af pragt og storhed midt i det moderne liv.

Fra Mannheim gik rejsen langs med Rhinen, til dels med skib, til Köln. Over Bremen og Hamborg nåede jeg hjem fra denne min første europæiske rejse. Helt fra latinskoledagene havde jeg gennemkrydset landet til fods og tog nogle miles vej som en spøg, men da jeg denne 
gang trådte ind ad døren til mit hjem, havde sommerens strabadser i den grad taget på mig, at min egen søster i første øjeblik ikke kunne kende mig. Efter denne højtspændte legemlige anstrengelse var det næsten som en hvile at skulle være soldat et års tid. Fra 1. okt. 1895 til 1. okt. 1896 lå jeg som et-årig frivillig ved regiment v. Manstein i Haderslev. Jeg tog del i uddannelsen til officer, underkastede mig den dermed følgende teoretiske og praktiske eksamen og forlod tjenesten som underofficer.

Studeringerne begyndte igen og det for alvor. Der skulle tænkes på eksaminer. Thi desværre formår kun få at løfte sig op over det synspunkt, at en god eksamen er studeringernes sidste mål. Livets egen store prøve, som følger efter, regnes for en bagatel. Jeg mødte i Kiel, hvor professorpersonalet imidlertid havde forandret sig en del. Den ungdommelige og livlige, meget moderne og frisindede Otto B. Baumgarten ${ }^{10}$ havde indtaget lærestolen i praktisk teologi. Han havde berejst landet og opsøgt provster og præster, hilst på personligheder, hvor han fandt dem, for at komme i forbindelse med provinsens teologer og kirkefolk. Munter og elskværdig som han var, optrådte han som en vindende agitator for en ny teologi og en ny tro. Han kunne i forbigående kalde sig selv en moderne pietist, og så meget sandt var der nok i denne betegnelse, at han følte en del mystiske grundstemninger i sin sjæl, som ikke ret ville nøjes med Ritsch ${ }^{11}$ eller Kaftan, et stykke uregistreret følelsesreligion, som han så regnede for pietisme. Uden tvivl havde han sans for det underfulde i al tilværelse, men undere som gennembrud af naturlovene, sagde han, »kan jeg på grund af mit almenfilosofiske standpunkt ikke anerkende«. Ild var der i ham, og han søgte at gøre enhver ung teolog til talsmand for en levende overbevisning og til en nidkær arbejder i menigheden. Han selv havde været præst og kom fra Baden. Jeg gjorde mig til en regel, fortalte han os, at besøge hvert hus i min menighed en gang hvert fjerdingår. Den slags mennesker kan ikke andet end påvirke deres omgivelser. Hvor dybt deres indflydelse går, bliver en anden sag. Baumgarten blandede sig i flådepolitik (var ven af storadmiral Tirpitz) og proletarpolitik, søgte og fik indgang i mange fornemme hjem i Schlossgarten og Dusternbrook og spiste til middag hos Ida HahnHahn. Han havde været gift, men tidligt mistet sin hustru.

I megen modsætning til hvad vi havde kendt før, tog han sig af sine studenter også uden for studiet. Da han opdagede, at jeg søgte et stipendium, og fik lidt indblik i mine økonomiske forhold, overra- 
skede han mig en dag ved at bede mig til middag hos sig, hvilket blev til en regel en gang om ugen. Han overraskede mig endvidere med en ny indbydelse fra et hjem, han selv havde omgang med. Inden jeg så mig om, sad jeg ved et godt middagsbord hele ugen rundt med undtagelse af søndagen. For mig betød det ikke så lidt at få god mad hver dag, men mere endnu betød det at færdes i de smukke hjem blandt intelligente mennesker. Hos etatsrådinde Prehn og hendes søster fru Kraus stødte jeg på navne, der er kendte fra Slesvigs og Holstens, også slesvig-holstenismens historie. Dette historiske blev dog, så vidt jeg husker, aldrig berørt ved bordet. Familien kunne dansk og havde slægtninge i Danmark. Bl.a. lod den unge danske kunstmaler Aksel Holm sig se på gennemrejse fra Paris. Etatsrådinden med sit indtagende smil og sine hvide dinglelokker foran ørerne var et af de elskeligste mennesker, jeg har mødt. Datteren Elise var portrætmalerinde og havde sin store umage med at male den livlige professor, hvis ansigt stadigt bevægede sig, og når det ikke bevægede sig, blev til en underligt intetsigende masse. Hos Müllenhoffs var der en slags circle af skønånder. Moderen boede som enke med en søn og en datter hos sig. Manden havde haft billedskærerværksted. Emma Müllenhoff, mor og datter af samme navn, er nu bekendte som oversættere fra engelsk, navnlig af Robinson, men også som selvstændige forfattere. Gennem den Prehn-Kraussiske familie modtog jeg en venlig indbydelse fra fru Kapitain-lieutenant Sattig, f. Hilmer, der var beslægtet med den v. Kroghske slægt og derfor opholdt sig i Haderslev, hvorfor de også kunne tale dansk. Med en del af disse mennesker har jeg opretholdt forbindelsen et stykke tid, men tabte dem desværre, eller de mig, til sidst af syne. Når jeg ser tilbage på denne tid og hele min studentertid, kommer det stadig på ny til min bevidsthed, hvor overordentlig langsomt min indre udvikling er gået for sig. Hele vejen var fattigdom min lod, næsten min skæbne, og det nationale dobbeltforhold, der næsten krævede to sjæle i et bryst, var en stadig hindring.

Der gik et år med ihærdigt arbejde, en tid lang i selskab med en kammerat. Den første teologiske eksamen afholdtes af de to biskopper (Slesvig og Holsten) hver med det hold, som var født inden for hans stift. Jeg sammen med en fire-fem andre mødte altså hos Slesvigs bekendte biskop, dr. Theodor Kaftan. ${ }^{12}$ En prædiken indleveredes i forvejen og måtte holdes i et menighedshus den sidste eksamensdag. Alt det øvrige var mundtligt og foregik i biskoppens stuer. Hovedresultatet af prøven var for mit vedkommende tilfredsstillende. ${ }^{13}$ 
De to følgende år gik med nyt eksamensarbejde, som dog blev afbrudt ved en militærøvelse i Kiel, fortsat i lejren ved Lochstedt og afsluttet i manøvren i Nordslesvig. Det sidste halvår tilbragte jeg hjemme hos mine forældre. Fader havde købt et lille hus ved siden af gården, og der fik jeg min arbejdsstue i ro for mig selv. Indtil kl. et sad jeg hver nat i mit ensomme kammer, hvor firben og rotter af og til lod sig høre, mens måren listede rundt på loftet. I den ene ende af stuen var to panelsenge, hvor husets beboere gennem tiderne havde søgt deres nattehvile. Der lå sidst Søren og Agnete, og i min barndom Mathias Væver og Stine. Nu er huset forsvundet som så mange andre i den lille by. Studenten er forsvundet med; det lille lys er slukt, og mindets svage gnist vil snart gå samme vej. Denne læsetid var de sidste måneder, jeg tilbragte i min gamle fødeby. ${ }^{14}$ Da færdedes jeg endnu en stund blandt sognets ungdom, mine fordums skolekammerater, sad i de gamles kreds og hørte på deres enfoldigt kloge tale, der ofte kom tilbage til det samme, og hørte ved gilderne folkets sange. Det klinger endnu alt sammen, men så langt borte fra, så dæmpet, så tungt og vemodigt. Mange af dem, der sang, ligger nu ved kirkemuren, andre er faret over havet, og de, der blev tilbage i byen, har bredt sig lidt mere, idet de tog naboens grund ind til deres eget. Af min slægt bor nu ingen mere i den minderige landsby, engang var vi så mange.

O. Baumgarten var min velgører, endnu skylder jeg ham tak. Men min sjæl kunne han ikke danne. Just i det tidsrum, jeg gik ud og ind hos ham, kom det langsomt til et indre opgør hos mig. Ikke teologien, men bibelen blev herefter min velgører. Jeg modnedes i nærheden af korset.

\section{Præstetiden i Flensborg 1900-03}

Efter de nye bestemmelser stod det kandidaterne, som ville til Nordslesvig, frit for at udtale et ønske om enten at komme på præsteseminariet i Haderslev ${ }^{15}$ eller til en præst for at uddannes i den praktiske præstegerning. Jeg valgte det sidste, da jeg ikke mente at trænge til den undervisning i dansk, som seminariet nærmest havde at byde. Min læremester blev da pastor N.C. Nielsen ${ }^{16}$ i Sommersted, og jeg fik dér, i modsætning til de akademiske problemdiskussioner, lejlighed til at se, hvorledes en troende præst - han var formand for IM i Nordslesvig - tog fat på menighedsarbejdet, og hvad han vidnede 
om på sin prædikestol. Under mit ophold i præstegården måtte jeg føre en dagbog, som indsendtes til konsistoriet i Kiel. ${ }^{17}$ Med dette lærevikariat var min uddannelse til ende. Nogle små sidespring blev der gjort undervejs. Således gennemgik jeg i Kiel et teoretisk kursus i sygepleje (navnlig forbinding af sårede i krigstilfælde), som efterfulgtes af et praktisk kursus i det store Eipendorfer Krankenhaus ved Hamborg. Efter embedseksamen måtte jeg tage et pædagogisk kursus ved præsteseminariet i Segeberg.

Endnu kom jeg, før der var et embede til mig, en tid som huslærer til Nustrup, hvor provst Gottfriedsen ${ }^{18}$ var i forlegenhed for en lærer til sine børn. I Nustrup herskede en helt anden luft end i Sommersted. Provsten var en klog og beregnende myndighed, tilmed en hjemmetysker, i teologisk henseende korrekt, men ingen ven af IM. Husets ungdom var naiv og lystig. Det kunne ske, at to-tre døtre efter middagsmaden, når de skulle til at gøre rent $\mathrm{i}$ spisestuen, lagde sig side om side langs ad bordet. Synge og spille gjorde de alle sammen. Da jeg hver søndag besøgte min kæreste i Haderslev, kan det siges, at det var muntre dage.

Kun fire måneder varede denne overgangstilstand. Efter samråd med konsistoriet opfordrede provsten i Flensborg mig til at overtage gerningen som hjælpepræst i Frue Sogn, hvilket tilbud jeg ikke havde mod til at afslå. En af de sidste dage i september blev jeg præsteviet på en såkaldt gejstlig synode i Sønder Brarup i Angel af generalsuperintendent Dr. Kaftan. Og så begyndte mit livs gerning.

Fra 1. oktober tiltrådte jeg et embede i Flensborg, ${ }^{19}$ som måtte have adskillige vanskeligheder for en ung og ny begynder. Officielt hed jeg hjælpepræst ved Frue kirke. I virkeligheden var jeg præst på tre forskellige steder. I den store Frue kirke, Mariakirken, måtte jeg sammen med kirkens to præster deltage i søndagsarbejdet efter en fælles plan. Men lidt længere henne i gaden lå den lille danske kirke, en gammel hospitalskirke, som kaldtes Helligåndskirken. Hver anden søndag skulle jeg forrette gudstjeneste her. Jeg var, som det hed i min instruks, i min gerning a) hjælpepræst ved Frue kirke og b) præst ved den dansktalende menighed i Flensborg. Foruden disse to kirker lå der endnu et kapel i Nystaden (Betlehems-kapellet, nu Sct. Petri kirke), som hørte med til det store Frue Sogn, men dog alligevel havde sin egen præst. Hos denne præst skulle jeg gøre tjeneste, navnlig ved børnegudstjeneste, fastegudstjeneste o.a. Af embedshandlinger kunne de tre præster lægge hen til mig alt, hvad de ikke selv kunne overkomme. 
Jeg selv anså mig hovedsagelig som dansk præst i Flensborg, og den menighed, der hver anden søndag samledes om min prædikestol, var mig langt den kæreste, den tilhørte mig alene. Det var en slags diasporamenighed, hvis medlemmer boede spredt over den store by, dog mest i den nordre del (Frue Sogn). Den havde også noget af den ynde over sig, som en diasporamenighed må have. Man slutter sig sammen med en større inderlighed og en næsten familiær fortrolighed. Præsten bliver let de enkeltes ven og tillidsmand, ja ofte deres forkæmper og forsvarer. Han er, når han står i deres midte, noget af en hjemmets talsmand, en profet og tolker af følelser, der ofte ikke må udtales med rene, klare ord, men kun må og kan få lyd i en hjertetone.

Det var dog ikke en udenlandsmenighed, jeg var blevet præst for, som de danske i Berlin eller London. Den danske menighed i Flensborg var helt anderledes stillet. For det første stod vi inden for den slesvigholstenske landskirke, var altså undergivet den kirkelige myndighed, provst og biskop, konsistorium og ministeren i Berlin, og man så os godt på fingrene. Den nye hjælpepræst, som endnu ikke havde fået fast ansættelse, skulle tage sig vel i agt for, hvad han gjorde. Dernæst var det ikke en koloni af indvandrere, skønt mange af menigheden, ligesom jeg selv, var tilflyttet fra det danske Nordslesvig. Og endelig lå det i sagens natur, at der ikke kunne være tale om nogen understøttelse fra Danmark. Dertil kom, at den kreds af mennesker, som udgjorde menigheden, stod i en stille kamp for sin nationalitet, en kamp som i og for sig ikke måtte få lov til at ytre sig i menighedslivet, men som dog selvfølgelig havde sin indflydelse på dette.

Der var øre inden for disse kredse i de dage, da den nye præst skulle tiltræde sit embede. Pastor Carstens, ${ }^{20}$ som helt siden 1864 havde været præst for den danske menighed, var ved overrumpling fra provstens side trængt ud af sin gerning og havde nedlagt embedet. Så snart det var sket, havde myndighederne indskrænket de danske gudstjenester til det halve, hver anden søndag. Dansk konfirmation var afskaffet. Men alle de i byen, som ønskede kirkelige handlinger (nærmest barnedåb, sjældnere brudevielse og meget sjældent begravelse) foretagne på deres danske modersmål, skulle have lov dertil, dog således at disse handlinger tilførtes kirkebøgerne i de sogne, hvor vedkommende boede.

Med indskrænkningen af de danske gudstjenester, der også kom som en overrumpling, var man ikke tilfreds, og der var derfor samlet mange hundrede underskrifter $\mathrm{i}$ byen under et andragende til konsistoriet $\mathrm{i}$ 
Kiel om at beholde den fulde række som hidindtil. Andragendet havde fået afslag, og der herskede en ikke ringe ophidselse i menigheden.

Under disse forhold betrådte jeg for første gang den danske kirke. Det var den sidste søndag i september, da den gamle Carstens, som var yndet af alle, tog sin afsked. Provsten havde givet mig det dårlige og taktløse råd at være til stede i kirken allerede den dag iført min præstekjole, for, som han sagde, at man med det samme kunne se den nye præst. Grunden var, som jeg senere har formodet, nok den, at den tyske provst ønskede at have et vidne under prædikestolen, mens den gamle sagde farvel til sin menighed.

Idet jeg kom ind og ville tage plads foran i kirken, stod jeg over for en dame og spurgte beskedent, om den plads var optaget? Jeg fik et kort og afvisende ja. Det var, som om der i det hele taget ikke var plads til mig på dette sted. Så tilegnede jeg mig en anden stol i den rolige bevidsthed, at jeg selv var et medlem af denne menighed, og at der i min indre var en følelse og en vilje, som berettigede mig til at sidde blandt disse mig ellers ubekendte mennesker.

Søndagen efter gik provsten med mig over i den samme kirke for at præsentere mig for min menighed. En regelret indsættelse skulle ikke finde sted, da jeg kun var hjælpepræst. Jeg stod ved hans side på gulvet, mens han holdt sin tyske tale, hvoraf jeg ikke mindes noget mere. Derefter gik jeg ind i det lille beskedne sakristi, hvor mine forgængere havde siddet gennem hundreder af år. Og her blev jeg glædeligt overrasket. På den ene væg var nemlig opslået et »velkommen « i guldbogstaver omvundet med grønt. Ingen så det uden mig, og ingen behøvede heller at se det.

Så holdt jeg da trøstigt min første danske prædiken i Flensborg, og jeg tænker, at de, der hørte den, forstod den godt nok. Dagen efter bad jeg kirkeværgen ved Frue kirke, som for resten selv var en dansk mand, om at få dette »velkommen«. Han sendte mig det straks i en stor konvolut, og det opbevares den dag i dag som et kært minde om mit første møde med min første menighed. Æresporte og ståhejer har jeg aldrig ønsket mig, jeg ville blive dårlig tilpas derved. Men et velkommen, som jeg alene forstår, og et stille håndtryk så upåfaldende, at end ikke den, der står allernærmest ved, lægger mærke dertil, det er, hvad der glæder mig.

Imens gik menighedens kamp for modersmålet i kirken sin gang. Man henvendte sig på ny til konsistoriet, og en søndag jeg trådte ind i kirken, hørte jeg en af kendte damer i Flensborg udbryde med 


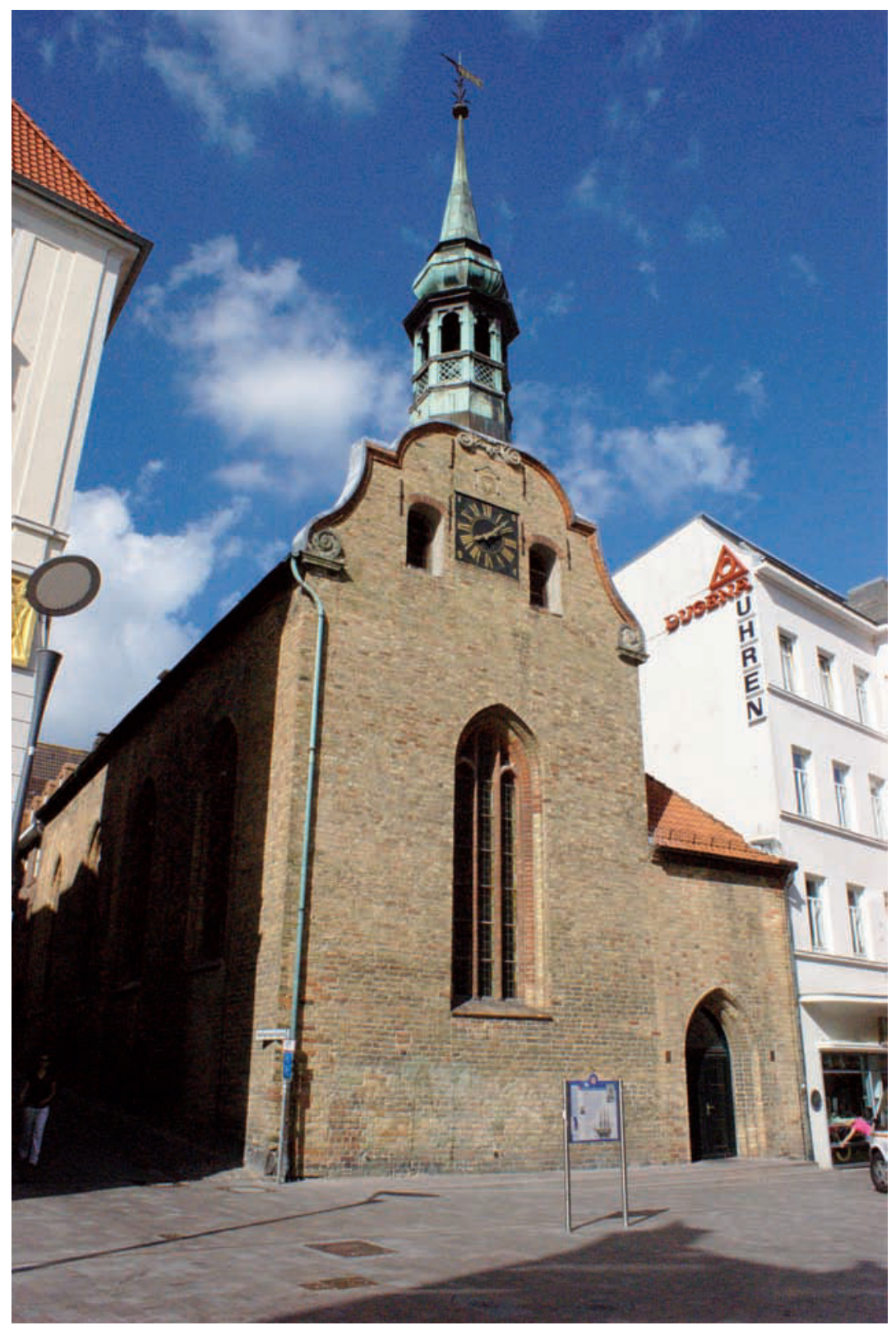

Helligåndskirken i Flensborg, nutidigt foto. Kirken er bygget $i 1386$ som kirke for Helligåndsstiftelsen, og siden 1588 har dansktalende flensborgere brugt den til gudstjeneste, se Henningsen og Runge 2006. Foto: Museum Sønderjylland - ISL. 
forbavselse: 2000? Så mange underskrifter havde det nye andragende fået. Der var tilløb til sejrsstemning. Men håbet blev til skamme, som så tit i den preussiske stat. Alt blev som det en gang var bestemt. En dag, da jeg mødte frem hos provsten, ${ }^{21}$ lå de mange underskrifter på hans pult, et helt bind. Han bladede i dem og viste mig nogle af navnene, hvorefter han slog bogen i og kaldte det hele en uforskammethed. Jeg tav dertil.

I de dage, som nu kom, forsøgte jeg at finde min menighed, hvilket ikke var så let. Den gamle præst havde ikke ført personregister. Jeg måtte spørge mig frem efter en hel del familier eller vente, til man kom og forlangte embedshandlinger af mig. Iblandt de kendte familier skal jeg nævne: Rigsdagsmand Gustav Johannsen, redaktør J. Jessen og hans stab (Kristiansen, Filskov, Svensson, Lausten, Christensen), vinhandler Kolding, grosserer Severin Schmidt, fru doktor Cordes, bankdirektørerne Nielsen og Thomsen. Andre familier som gasværksbestyrer Madsen og værftsdirektør Bredsdorff var vel dansksindede og dansktalende, men kom sjældent i den danske kirke. Endnu må dog nævnes kirkens gamle præst, som blev boende i byen, og dens organist Kristiansen, hvis to brødre var præster i Nordslesvig. Begge disse mænd har trofast og vedholdende stået til tjeneste for den danske menighed og kom mig i møde med megen velvilje. Men når jeg her har nævnt en række navne, hvortil der kunne være mange flere, da siger jeg ikke, at disse familier stod mig nær frem for andre. Tværtimod. Jeg har haft min gang i mange små og mindre velstillede hjem, og der har der knyttet sig bånd, som ikke er løst den dag i dag. Særligt har jeg at mindes et lille samfund af troende mennesker, som optog mig i deres midte og lod mig lede deres samtalemøder.

Trods det at gudstjenesterne, som det hed i klageskriftet, mere og mere fik præg af tilfældighed, da spredt boende mennesker i en stor by let kan komme i vildrede med, på hvilken søndag der prædikes, så blev kirkebesøget dog i jævn tiltagende, så vi i løbet af et par år kom op på 100-120 deltagere i de sædvanlige søndagsgudstjenester. Til de store fester var kirken fyldt. Mærkværdigvis brugtes endnu den danske salmebog (kongerigets), ikke den nordslesvigske. Senere har man indført den sidste, vel af den grund, at mange familier, som kom fra Nordslesvig, havde deres salmebog med og helst ville benytte den.

Da jeg kom til Flensborg, stod den gamle store Frue kirke under 


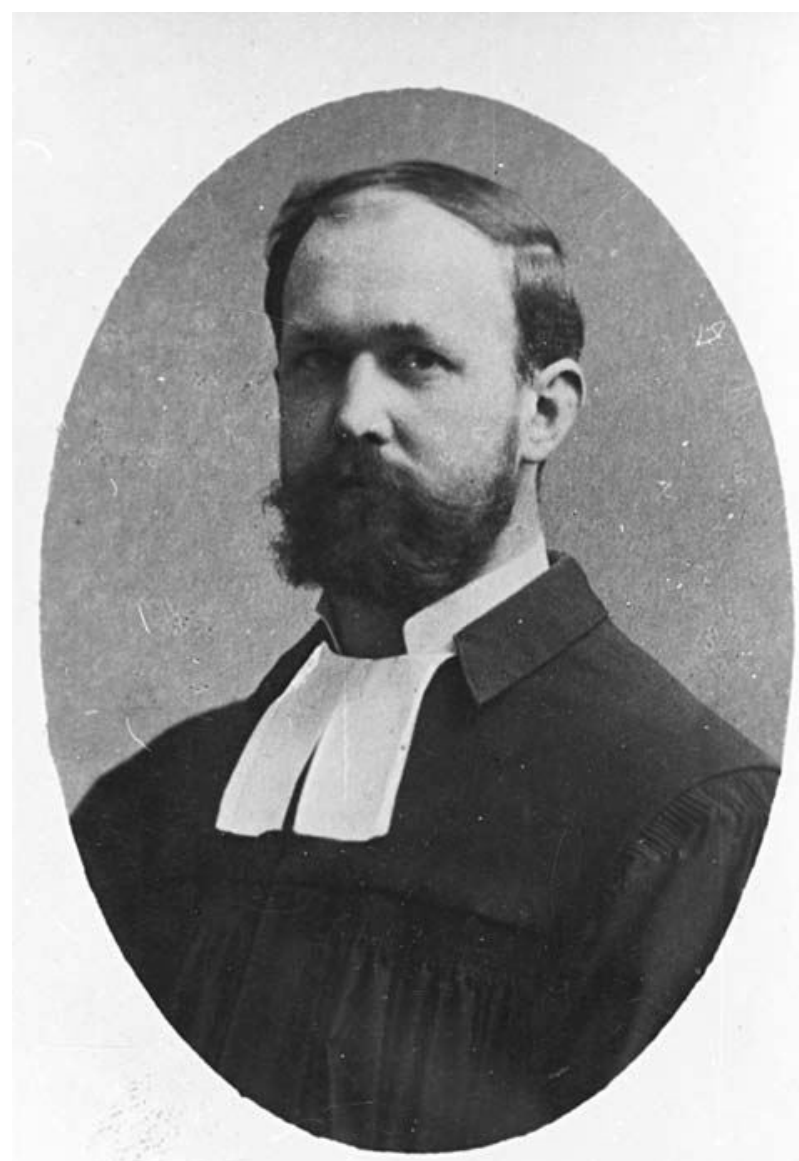

Carsten Petersen som ung præst i Flensborg, 1900-03. Foto: Museum Sønderjylland - ISL.

reparation. Den tyske menighed havde da taget den danske kirke, Helligåndskirken, i brug. Vi måtte lempe os efter hinanden, hvilket dengang altid betød, at danskerne måtte lempe sig efter tyskerne. Men det gik nu alligevel.

Værre blev det, da Jørgensby kirkemenighed med sin hensynsløse stræberpræst fik lov til at holde gudstjeneste i den danske kirke, mens deres egen blev bygget. Pastor Lensch, ${ }^{22}$ der i genforeningstiden er blevet bekendt som en af Flensborgs værste agitatorer mod Danmark, havde en unobel, næsten uanstændig karakter. En skønne dag indgik 
han til de højeste kirkelige myndigheder med en begæring om at få vor kirke overladt til alle højmessegudstjenester. Dristigt påstod han, at den danske gudstjeneste kun besøgtes af et lille antal mennesker. Heldigvis var provsten ingen ven af denne usympatiske præst - det være sagt til ære for provsten. Og da jeg mødte hos ham til mundtlig drøftelse af denne sag, erklærede provsten, at det var min og menighedens ret at have vor gudstjeneste som hidindtil. »Det må De gøre gældende«. Ja det var godt nok, mente jeg, men i mit stille sind tænkte jeg videre: Den ret har du jo trådt under fødder. »Jo det må De holde på«, sagde provsten videre. Og så holdt jeg på det og lagde for resten ikke fingrene imellem. Jeg var nu ikke så helt ny mere og begyndte at have min mening i visse sager. Pastor Lensch fik ikke sin vilje. Men senere - det var efter min tid - spillede han den danske menighed et puds, som søger sit sidestykke.

Helligåndskirken ejedes af klosteret, som ligger i Sct. Nicolai Sogn, men den danske menighed havde ældgammel hævd på at bruge den til sine gudstjenester. Det lykkedes nu for den listige præst i al stilhed at lave en handel med klosterbestyrelsen. Man overlod menigheden i Jørgensby Helligåndskirkens prægtigt udskårne prædikestol for en passende sum, og mod at der sattes en simpel stol i stedet. En dag mødte en mand med en trækvogn foran den lille kirke, prædikestolen blev læsset på, lidt tilhyllet og forsvandt for stedse fra sit gamle sted. I de dage kaldte man præsten kirkerøveren. I modsætning til disse angreb fra fjendens side må jeg dog bekende, at jeg selv også havde udpønset en overrumpling. Der planlagdes ved vintertid at holde gudstjenesten i kapellet i Nystaden både formiddag og eftermiddag. Jeg foreslog da i forhandlingen i kirkeforstanderskabet - uden at det først havde været sat på dagsordenen - at da en stor part af Nystaden var dansktalende, og det var mig, som skulle holde en del af de planlagte gudstjenester, det da måtte ordnes sådan, at der blev dansk prædiken hver anden søndag. Overrumplingen lykkedes. Provsten, som havde en godmodig side, og som vel stadig følte sig lidt ilde til mode ved sin egen optræden over for danskerne, gik ind på mit forslag. Kun en af de otte kirkeældste, en mand af god dansk slægt, satte sig imod, de andre bifaldt eller tav.

Naturligvis blev disse nye gudstjenester ordnede således, at de korresponderede med dem i den danske kirke. Menigheden havde altså i denne vinter sit fulde antal gudstjenester. Men også kun den ene vinter. Kapellet i Nystaden, som dog ikke rummede så få mennesker, 
var fyldt straks den første gang og blev ved at være det. Men just dette faldt tyskerne svært for brystet. Provsten måtte høre ilde for det og blev nervøs. Han kunne knap afvente pinsetiden, da disse gudstjenester skulle ophøre af sig selv, og de blev ikke optagne igen. ${ }^{23}$

En skuffelse mødte mig straks i begyndelsen, idet jeg ikke fik lov til at gifte mig. Min forlovede havde i overilelse lejet en lejlighed og anskaffet en del møbler. Lejligheden kunne jeg slet ikke benytte, da den lå for langt borte fra min arbejdsmark, og med giftermålet måtte vi vente i tre år. Men ellers mødte jeg megen velvilje, særligt i danske hjem. Samtidig med mig kom en ung rhinlænder til byen for at overtage gerningen som garnisonspræst. Han opsøgte mig straks og lejede et par værelser i samme hus. Vi var begge fremmede i byen, var nye i gerningen og havde omtrent samme arbejdsvilkår, idet han også af navn kun var hjælpepræst. Det første, jeg kiggede efter, da jeg steg ud af toget på banegården, sagde han, var jernbanekøreplanen. Jeg måtte overbevise mig om, hvorledes jeg kunne komme hjem igen. Efter et års tid drog han til Kina for at gøre tjeneste som feltpræst under grev Waldersee i bokseroprøret. Jeg har nu tabt ham af syne. Med hans eftermand havde jeg en del samkvem.

I det hele var der dengang et stærkt sammenhold blandt de flensborgske præster. Hver mandag mødtes de til konvent rundt om i de forskellige præstegårde. Kun diakonissestiftelsens forstander holdt sig udenfor. ${ }^{24}$ Han havde sine egne konventer (conferencer) med tilslutning fra hele landet. Man afholdt halvårlige ti-dagesmøder, hvortil sådanne mænd og kvinder måtte slutte sig til, som anså bibelen for det fejlfri Guds ord. Senere havde jeg min plads i denne kreds. Ved mandagskonventet nøjedes man med kollegialt samvær uden at drøfte konfessionelle og dogmatiske problemer. Nogle af deltagerne i dette konvent var begavede og betydelige mænd. I mine øjne den fortræffeligste og mig den kæreste var pastor Wurmb ved kapellet, senere Sct. Petri kirke i Nystaden. Han havde været en kvik og åndrig redaktør af det konservative præsteblad ${ }^{25}$ og var en fordomsfri personlighed, som danske folk mødte med sympati. En kraftig karakter, et dybt, men ofte tungt sind, en vittig tunge, en prædikant med patos, en tænker og kirkepolitiker tillige. Desværre følte han sig stadig tilsidesat og undgik ikke at blive bitter. Jeg blev lidt af hans fortrolige og havde lejlighed til at drøfte evighedsspørgsmål med ham. En modsætning til ham var den muntre og trivelige provst, den senere geheimeråd Niese. Han havde en god og sund forstand, et hurtigt nemme 
og en ærlig vilje til at arbejde sig selv opad. Desværre kunne han ikke dansk, og vejen til Slesvigs bispestol var derfor på forhånd lukket for ham. Ved Nikolaj Kirke stod i sin fejreste blomst hr. Birkenstaedt, en skønånd, som hver søndag fra prædikestolen i den skønt hvælvede kirke udstrøede sine elegante og formfuldendte sætninger over en talrig forsamling. Præsten ved Sct. Hans kirke var den fint dannede Fr. Andersen, ${ }^{26}$ en svoger til den bekendte kunstner Harro Magnussen. I hine år var han redaktør af det konservative præsteblad og en af den kirkelige konservatismes førere, men gjorde nogle år senere i al stilhed en fuldstændig kovending, idet han pludselig trådte frem som forfatter af en meget tyk bog, i hvilken han drog til felts imod jødedommen, forkastede det Gamle Testamente etc. - en slags forløber for tysk kristendom. Dansktalende var kun den gamle pastor Carstens og jeg. Men præsten på diakonissestiftelsen, som havde været præst i Nordslesvig, var fuldstændig fortrolig med sproget. Et par andre kunne til nød forstå lidt dansk.

Om min præstevirksomhed i det enkelte skal der ikke siges noget her. En stor del af de folk, jeg fik med at gøre, var både moralsk og økonomisk lavtstående. Dertil hørte i den sidste tid glasfabrikken med dens arbejdere. Mange lig måtte jeg hente på sygehusene og ledsage til kirkegården, fremmede og ukendte, forulykkede og selvmordere, strandede eksistenser. Det løb ikke altid af uden fortræd og klaps i avisen. Inden for den danske menighed har jeg taget del ikke blot i den stille kamp mod tyskeriet, men også i de enkelte familiers glæde og sorg. Her mindes jeg særligt to begivenheder: Gustav Johannsens begravelse ${ }^{27}$ og ægteparrets Coldings guldbryllup.

Om aftenen, da Gustav Johannsens lig overførtes fra hjemmet til den lille danske kirke, stod jeg foran alteret og tog imod det stille tog. I den frie bøn jeg bad, inden følget forlod kirken igen, mindedes jeg det hedengangne medlem af den danske menighed uden at berøre hans politiske virksomhed. Ved jordfæstelsen næste dag talte kirkens gamle præst fra alteret. Han beklagede sig over for mig, at han havde måttet lære sin tale udenad, hvilket i hans alder ikke var så let. Omkring graven samledes en skare af over tusinde mænd fra alle egne af Nordslesvig og fra det gamle Danmark. Korrespondenter banede sig vej gennem mængden og tog plads lige op ad den pæne grav med deres notitsbøger i hænderne. Til denne forsamling, der vejede hvert ord, måtte jeg tale, vanskeligt nok for en ung mand i statskirkens tjeneste, dobbelt så vanskelig for det danske hjerte, som havde så 
meget, der kunne være sagt på dette sted. Efter begravelsen, ved mødet i borgerforeningen, samlede redaktør J. Jessen referenterne for de fremmede blade for at give dem gavnlige vink om, hvad der måtte siges i offentligheden. Kun en eneste avis antydede, så vidt jeg ved, at det måtte være en dansk mand, som talte ved graven, en ytring som den afgåede tyske provst benyttede til at give mig et godt råd om at være forsigtig, da der »vigileredes« så meget.

\section{Præst i Brarup 1903-11}

Da jeg havde været præst i Flensborg i hen ved to år, tilbød provsten at omdanne embedet til et fast embede med pensionsberettigelse, således at jeg kunne gifte mig og blive, hvor jeg var. Da var jeg imidlertid blevet ilde tilfreds for længst med den hensynsløse måde, provst og konsistorium havde mødt mig på, og længtes efter et selvstændigt arbejde, helst på landet. Jeg nægtede derfor at gå ind på forslaget, hvilket provsten heller ikke syntes at beklage. I den tid søgte jeg en eller anden udvej i udlandet, som dog ikke ville åbne sig for mig. Der hengik et års tid endnu. Endelig i juli 1903 blev jeg valgt til sognepræst i Brarup i Sydtønder Provsti. Ved afskeden fra Flensborg modtog jeg fra de danske en takadresse og et maleri af Lyksborg Slot, malet af J. Bredsdorff, en broder til værftsdirektøren. ${ }^{28}$

Før min tiltrædelse holdt min forlovede og jeg bryllup hos mine forældre hjemme i Møgeltønder. Brarup Sogn ligger 13-14 km syd for Tønder. To store færdselsårer gennemskærer sognet. Gennem kirkebyen går landevejen fra Tønder til Læk og Nibøl (Husum). Forbi de to andre byer, Uphusum og Holm, går jernbanen Tønder-Hamborg, med station Uphusum, dengang Holm. Beboerne er og var rent danske i deres folkelige art, men tyske i sind. Sproget var næsten i alle hjem det slesvigske folkemål, iblandet en del tyske ord. Ikke så få gamle danske udtryk, som nu er forældede og glemte nordpå, var endnu i folkets mund i disse mellemslesvigske egne. En del ord var åbenbart af frisisk oprindelse. Tysk og frisisk taltes ellers næsten kun af indvandrere.

I øvrigt skal med hensyn til sprog og folkelig skik siges, at den skildring, som Feilberg ${ }^{29}$ i sin tid gav deraf, litterært og folkloristisk set kan være et mesterstykke, men rent menneskeligt betragtet og med henblik på en præsts forhold til sine sognebørn må jeg give dem af beboerne ret, som i dette stykke forargedes på deres præst. Den 
mellemslesvigske befolkning var og er sikkert endnu en så redelig og gennembrav og hæderlig menneskeart og et så udmærket folkefærd at leve iblandt for præst og lærer, at den synes mig for god til at afmales, som det er sket i Feilbergs bog. Jeg tænker på St. St. Blicher, hvor helt anderledes han har skrevet fra heden og om heden, selvom det er digt. Ikke så sært at jeg, bortset fra den politiske tyskhed, hurtigt forstod dette folkefærd. Jeg kunne stå i vestkanten af mit sogn og se den kirke, hvori jeg var døbt. Men trods det, at jeg sad i et bælte, som lå lige op ad det danske Nordslesvig, så var der dog en usynlig grænse, som skilte.

Vel var Tønder vor købstad, og på markederne dér mødtes og blandedes de handlende fra syd og nord, men der var ikke tale om nogen påvirkning nordfra. I ældre tider var der en skare af nørrejyske tjenestefolk kommet til sognet, og en del af dem var blevet bosiddende, men deres afkom var opslugt af det indfødte element. $\mathrm{Nu}$ var kun ringe samkvem med norden. Sjældent tog en karl eller pige fra Nordslesvig eller Danmark plads i de mellemslesvigske egne. Vi har engang forsøgt at annoncere os til en pige nordfra, men det lykkedes ikke. En gang fik vi en af vor slægt, men hun blev ked af det efter et år. Langt den største tilknytning var sydpå. Med undtagelse af nogle eksemplarer af Flensborg Avis, som læstes, kendte man kun tyske aviser og tyske bøger. I folkeskolen lærtes ikke en stavelse dansk, skønt de fleste børn ikke forstod et tysk ord, når de mødte første gang. Al fortsættelsesundervisning søgtes sydpå. Sjældent hentede en ung bonde sin hustru fra Nordslesvig, og skete det, så fik hun ikke lov til at bringe noget dansk åndsliv med sig. Den eneste danske tale lød i kirken i en gudstjeneste en gang om måneden. Men selv i denne var det kun præsten, der talte dansk, menigheden sang tyske salmer og svarede på tysk, når præsten fra alteret hilste dem på dansk.

I de få år mellem krigene havde det været helt anderledes. Tilstanden i Brarup Sogn i dette tidsrum var et bevis for, hvorledes sagerne ville have udviklet sig, dersom ulykkesåret 1864 ikke var kommet. Hvor mange gudstjenester der da holdtes, mindes jeg ikke mere, men kirkebøgerne viste, at i de år var der store altergange også ved disse gudstjenester, ofte større end ved de tyske. Den daværende præst var københavner og ikke fortrolig med landsbyforhold, alligevel var han vellidt. Siden da var gudstjenesten på den danske søndag blevet til en torso og kun besøgt af 20-30 personer. Tysksindede familier holdt ikke af at give møde, skønt de lige så godt og bedre måtte kunne følge med under en dansk prædiken som under en tysk. 
At jeg ved præstevalget sejrede over de to andre kandidater, skønt jeg var dansksindet, kan kun forklares derved, at de to medbejlere hørte til den slags, der vanskeligt formår at gøre sig gældende ved en afstemning. Men trods det, at man godt nok vidste besked om min nationale herkomst og følelse, og til trods for at jeg straks fra den første tid begyndte at benytte mig af det danske omgangssprog - til forargelse for nogle hjemmetyske bønder - blev forholdet $\mathrm{i}$ det store og hele godt. De kristelige og alment menneskelige tilknytningspunkter gjorde sig så stærkt gældende, at det nationale, som jeg selvfølgelig aldrig betonede, trådte i baggrunden.

Præstegården havde ikke og fik ikke i min tid nogen flagstang, ligesom jeg slap for at deltage i fester med tysk-nationalt præg. En af mine forgængere yndede at møde ved slige lejligheder i militæruniform. Min eftermand lod rejse en flagstang, så snart han var flyttet ind i præstegården. Kun en eneste gang trak det op til uvejr. Et par år efter at jeg var ankommet til sognet, døde redaktør J. Jessen i Flensborg. Efter et af ham selv udtalt ønske skulle jeg forrette tjenesten ved hans jordefærd. Nogen let sag var det ikke, skønt den afdøde havde bestemt, at alt skulle foregå i dybeste stilhed. Men jeg mente ikke at kunne afslå. Hele mit bidrag til højtideligheden bestod i fremsigelsen af trosbekendelsen og en bøn, foruden den oplæste tekst i kapellet og det sædvanlige ved graven. Men navnet Jessen var et kampråb. Og rejsen til Flensborg blev end mere understreget derved, at en fremmed præst måtte overtage en begravelse for mig hjemme i sognet, mens jeg var borte. Tilmed blev jeg kaldt endnu en gang til Flensborg, da den gamle Colding døde. Da derfor en gammel ukirkelig slesvigholstener nogen tid efter afgik ved døden, og det forekom lidt underligt, at denne mands lig skulle opstilles i kirken, fik jeg besøg af en broder, som læste mig teksten i den anledning. Han slog i bordet for mig, mens vredestårer trillede ned ad kinderne. Samtidig lod han mig forstå, at jeg forholdt mig, som jeg gjorde, fordi de var slesvigholstenere. Idet han gik bort, fik han et nyt raserianfald og påstod, at hæderlige folk i sognet ville jeg ikke vise den tilbørlige ære, men rejse til Flensborg og begrave denne forbryder, det kunne jeg nok! Da tog jeg mod til mig, gik helt ind på manden, som allerede stod ude i haven, og spurgte, hvad han mente. Så tav han stille og luskede af.

Det undrer mig, at denne begivenhed ikke fik værre følger, end den gjorde. På mine ældre dage havde jeg handlet noget anderledes. Jeg formoder dog, at kirkebesøget siden den tid formindskedes noget. 
I øvrigt gik alt roligt og vel. I næsten hvert eneste hjem har jeg mødt en gæstfrihed, åbenhed og fortrolighed, som jeg nu stundom længes efter. Jeg tænker tit tilbage på Brarup Sogn med venlige tanker. Alligevel må jeg sige, at i det øjeblik Verdenskrigen brød ud, takkede jeg Gud for, at jeg ikke var dernede. Hvem ved, hvad der i krigsårene og under afstemningens ophidselse kunne være hændt mig.

For mit personlige liv blev årene i Brarup en grødetid med kræfternes vækst og med opdukkende arbejdslejligheder. Mange muligheder gik forbi min dør - og min dør forbi. Ved omflytningen fra Flensborg fra de tre års uro og slid syntes det mig, at jeg var kommet på aftægt. Det første, jeg gav mig til at sysle med som en art rekreation, var mit sogns historie. Jeg gennemgranskede kirkebøgerne og arkivet, opsøgte gamle slægtspapirer på gårdene, forsøgte at forstå stenenes tale i kirkebygningen og studerede i et par arkiver. En lille del af det samlede stof blev trykt $i$ et menighedsblad, som jeg udgav en gang om måneden. Men arbejdet blev snart afbrudt, idet jeg droges mod andre opgaver.

Der var i de år begyndt et organiseret vækkelsesarbejde i Sydslesvig og Holsten, i lighed med Indre Mission i Danmark og i modsætning til den kirkefjendske Gemeinschaftsverein. Man benyttede navnet Evangelisationsverein. ${ }^{30}$ Jeg blev medlem af foreningen og var en kort tid medarbejder i dens rækker. Snart førtes jeg også ind i det breklumske hedningemissionsselskabs kredse og var en kort tid hjælpelærer ved deres missionsskole. Med den nordslesvigske IM havde jeg derimod kun ringe forbindelse, ligesom jeg heller ikke har set nogen af dens sendebud i mit sogn. Mit personlige og teologiske samkvem havde jeg næsten helt med den sydlige del af landet. Jeg blev medredaktør af det gamle konservative Schleswig-Holstein-Lauenburgische Kirchen- und Schulblatt og havde bl.a. der en fejde med og om biskop Kaftan og hans uklare teologi. ${ }^{31}$ Også ved det breklumske søndagsblad var jeg regelmæssig medarbejder. ${ }^{32}$

Nogle foredrag holdt jeg på præstekonventerne i Flensborg, Kiel og Mölln (Lauenburg). Ved lærekurset i Mölln holdt jeg et to-dages foredrag om danske kirkelige forhold, som vakte tyskernes interesse. ${ }^{33}$ Stykker deraf blev bragt i forskellige kirkeblade og bragte mig en dag i forbindelse med en professor i Amsterdam, som meget bad om at få nogle af de danske kirkelove tilsendt. Man drøftede i de tider meget spørgsmålet om sognebåndsløsning i Tyskland, måske også i Holland. ${ }^{34}$ Forud for dette foredrag havde jeg været på et læn- 
gere ophold i København for at få lejlighed til at se tingene på nærmere hold, navnlig også for at studere det sidste store kirkelige udvalgs arbejde. Jeg besøgte prof. Scharling, stiftsprovst Paulli, pastor Martensen-Larsen, hofpræst Kissmeyer o.a. Kissmeyer skulle have besørget arbejdet i Mölln, men måtte af hensyn til hoffet trække sig tilbage, da der opstod en politisk spænding mellem Danmark og Tyskland.

I det store og hele efterlod disse besøg ikke noget glædeligt indtryk hos mig, og jeg har aldrig mere søgt indgang i København hos folk, som jeg ikke kendte. Jeg, som kom fra en præstegård på landet, hvor vi med beværtende gæstfrihed havde modtaget adskillige studierejsende nordfra, ${ }^{35}$ syntes ikke om de mange lukkede døre i København, bag hvilke man behandledes med elskværdighed og høflighed og så kunne gå. Til undskyldning for præsterne skal jeg anføre, at jeg ifølge hele min indstilling ikke så mig i stand til at åbenbare mig som en dansk mand. Men jeg talte, sagde man, sproget rent og godt, og jeg stod som dette sprogs sydligste vagtpost i Slesvig. Dette kunne vel have interesseret en og anden, ikke for personens, men for sagens skyld. Thi det var en af de bedste og tillige tungeste følelser, jeg stod med i Brarup, at jeg havde tjeneste som den danske kirkes yderste forpost, og det var en ensom post. I alle omkringliggende sogne var den sidste rest af dansk kirkeliv forsvundet. Ingen af mine nabopræster kunne tale dansk. Brarup var en fuldstændig oase og blev da stundom også kaldt det danske Brarup. Jeg læste dengang biskop Kochs bog om præst og menighed ${ }^{36}$ og syntes, at han på en måde var min biskop. Forresten har jeg også benyttet bogen til et foredrag på en gejstlig synode, dog ikke i Mellemslesvig.

Muligheder nævnte jeg, som gik min dør forbi. Det var underligt med de mange tilløb, men at det kun blev til tilløb, var vel, når det kommer til stykket, min egen skyld. Således lod biskoppen mig en dag komme til Tønder og bad om en samtale med mig. Provsten i Nørretønder Provsti var gået af, og det gjaldt om at få en efterfølger, hvilket ikke var helt så let. Samtalen med biskoppen blev fra hans side til en sondering af mit politiske (nationale) sindelag. Jeg bestod ikke. Uden at ville tage stilling til de gængse kampspørgsmål erklærede jeg dog at være af dansk slægt, at mit blod var dansk, et rent naturforhold, som ikke kunne forandres. Talen førtes så ind på noget andet.

I det hele taget fik jeg tit at mærke, hvor snævre de grænser var, 
man som dansksindet nordslesviger bevægede sig i. I Breklum ${ }^{37}$ omgikkes missionsinspektøren med tanken om at kalde mig på en plads ved sin side, men måtte opgive det, fordi han ikke mente at få biskoppens ja dertil. På samme måde var bestyrelsen for præsteseminariet $\mathrm{i}$ Kropp på vej til at lægge forstandergerningen i mine hænder, men troede dog ikke at turde gøre det. Havde man bedt mig derom, havde jeg formodentlig sagt ja, da jeg godt kunne lide at have fået min gerning blandt ungdommen. Alt imens begyndte biskoppen at blive påtrængende med et forlangende om at få mig flyttet til Nordslesvig. Han fik mig til - uden nogen ansøgning - at lade mig præsentere til præsteembedet i Gråsten og Adsbøl..$^{38}$ Der skulle ikke være valg, men embedet besættes umiddelbart af konsistoriet. Jeg tog derover og holdt den lovbefalede prøveprædiken, hvorefter menigheden havde 14 dage til at komme med indsigelser mod min kaldelse. Snart efter modtog jeg breve fra folk, som ønskede mig dertil, med sørgmodige udtalelser om, at der fra en vis side gjordes alt for at holde mig borte. Jeg kunne nemt gætte, hvad der var i vejen. På Gråsten Slot boede hertug Ernst Günther, kejser Wilhelm II's svoger. ${ }^{39}$ Det var ham, der ikke kunne tåle en dansksindet præst på prædikestolen i slotskirken. De tysksindede i byen klyngede sig til ham. Vejen til Berlin var for hertugen let at gå og førte hurtigt til målet. Endnu en gang kaldte biskop Kaftan, som ikke holdt af at se sine planer gennemkrydsede, mig til sig og spurgte: ønsker De, at vi i konsistoriet forsøger at føre sagen igennem, mod Berlin? Ellers vil jeg bede Dem om at tage Deres ansøgning tilbage. Da jeg slet ikke havde indgivet nogen ansøgning og ikke brød mig om at komme til Gråsten, faldt det mig let at vælge den sidste vej. Jeg kom derefter på valg i Brede Sogn på vestkysten, men blev ikke valgt. ${ }^{40}$

Foruden mit medarbejderskab ved forskellige blade og andagtsbogen I Jesu fodspor blev et par manuskripter færdige i Brarup, hvoraf dog kun det ene - en lille andagtsbog for unge med titlen Rejsemåltid blev trykt og solgt. En afhandling om Søren Kierkegaard, som jeg havde tænkt at erhverve den filosofiske doktorgrad med, blev ikke færdig, da jeg i det samme blev forflyttet og dermed kastet ind i andet arbejde. ${ }^{41}$ En tid lang havde jeg med interesse fulgt det store IMarbejde, som havde sit midtpunkt i Vupperdalen (ved Rhinen). Jeg tilbød da ved lejlighed min kraft, om man kunne ønske at bruge den. Efter en tids forløb modtog jeg et venligt forslag om at overtage en gerning dér. Da havde jeg allerede sagt ja til en henstilling om at flytte 
nordpå til mit egentlige hjemland. Til Rhinlandet måtte jeg altså sende et nej. Også her var Guds finger tydeligt med i spillet. Under Verdenskrigen ville livet ved Rhinen nok være blevet utåleligt for mig, hvis ikke jeg ville prisgive mit fædreland. Det er med smerte, jeg senere har læst Henrik Steffens levnedsløb. Andre af vore landsmænd har båret sig ad på samme måde. Jeg vil aldrig kunne forstå dem. Men noget andet vandt jeg i Brarup, som fik afgørende betydning for mit personlige liv og gav mig tanker om ikke en ny, så dog en mere afgjort og bestemt retning. Jeg kom til at fordybe mig i Søren Kierkegaard. Denne ensomme mand blev for mig den store danske tænker, inderlighedens ydmyge apostel, den ubetingede redeligheds talsmand, det dybeste og mægtigste, jeg fandt i nordisk åndsliv. En biografi af ham har jeg leveret i Nordslesvigsk Søndagsblad, og en forkortet oversættelse deraf gik til den gamle Hengstenbergsche Kirchenzeitung. ${ }^{42}$

Et par tvillinger fødtes os i Brarup. Vi måtte lægge dem i jorden efter nogle få dage.

Af rejser, som jeg foretog i disse år, skal jeg kun omtale min deltagelse i en kongres for kirkebygning i Dresden, vistnok 1907. Det var kun en stille deltagelse, men den berigede mit kendskab til de problemer, som unægtelig kræver en løsning inden for den moderne protestantiske kirkebygning. Interessant var mig især modsætningen mellem luthersk og reformert opfattelse og ligeledes de af den gamle Sulze frembragte idéer om »intime gudstjenester og kirkehuse «. ${ }^{43}$

\section{Sognepræst i Magstrup 1911-32}

Med året 1911 gik jeg ind i et nyt afsnit af mit liv. Mit hjemland Nordslesvig åbnede sine døre for mig, idet man fra Magstrup Sogn forespurgte, om jeg ville være deres præst. Samtidig udbredte biskoppen for mig alt, hvad der var af ledige embeder deroppe; jeg skulle tage, hvad jeg ønskede, bare jeg ville komme. Det blev så Magstrup og Jegerup, som dengang havde fælles præst, men som i nærmeste fremtid skulle skilles i tre sogne med to præster.

I elleve år havde jeg virket i Mellemslesvig i den del af mit folk, som var prisgivet til langsom undergang. Dag for dag slikkede bølgen sydfra noget bort fra vor strand, mens vi stod og så derpå. Fra stund til stund svandt vore kræfter, den ene segnede efter den anden, uden at der kom nye i deres sted. Mange gange steg det spørgsmål op i vort indre, er der håb tilbage? Håb om opstandelse, om en fremtid? 


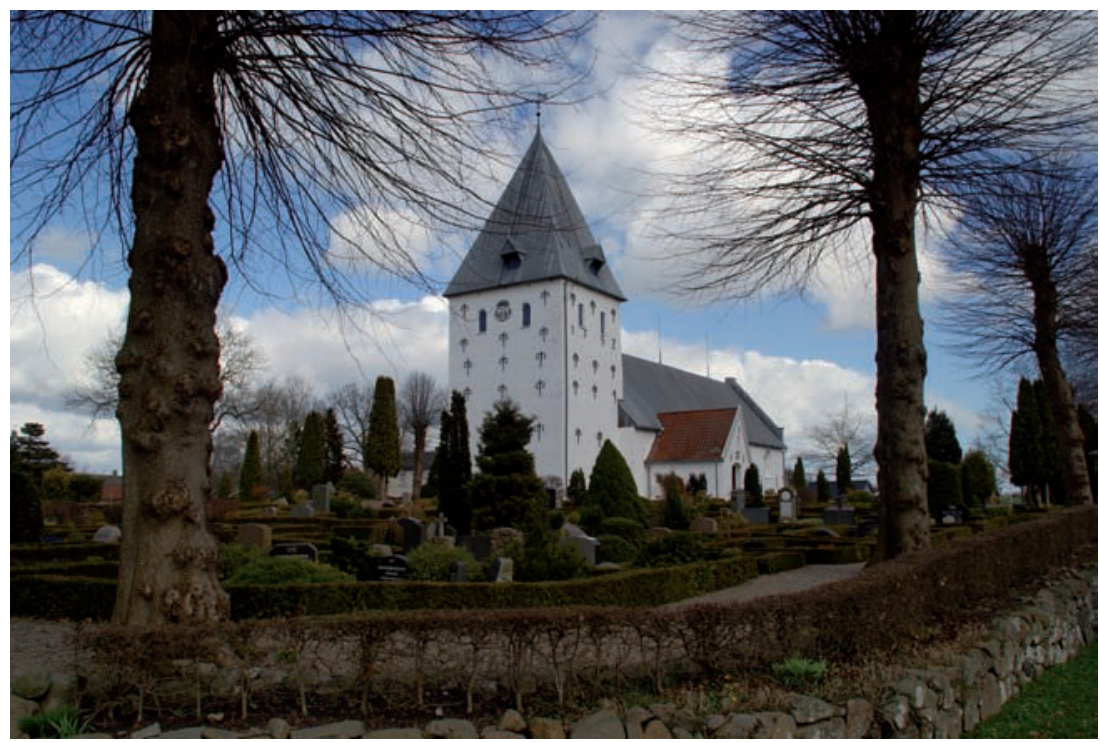

1911 flyttede Carsten Petersen til Nordslesvig som sognepræst i Magstrup, beliggende ved landevejen Haderslev-Jels. I øvrigt forekommer også stavemåden Maugstrup. Her ser vi sognekirken, romansk skib med fem gotiske tilbygninger, smukt beliggende sammen med præstegården. Foto: Jens Bruun.

$\mathrm{Nu}$ fik jeg min plads blandt dem, som endnu kæmpede en livlig kamp, som det syntes med frisk mod og godt håb. Det var just i de tider, da danskheden i Nordslesvig syntes at skulle over i offensiven, idet hullerne, som engang var opstået ved udvandring, nu fyldtes igen. Også på kirkelivets område ville en national bølge lade sig til syne. Mange alvorlige kristne begyndte at føle sig utilpas ved den rene neutralitet. Et enten-eller rykkede dem ind på livet.

Min opgave kunne her lige så lidt som i Mellemslesvig blive at tage offentlig del i folkenes kamp. Dette var i og for sig en umulighed for en præst i den tyske folkekirke - man betænke at en sådan præst engang blev anklaget og måtte søge sin afsked på grund af et pibehoved med Dannebrog - men jeg stod desuden inden for den kirkelige retning for Indre Mission (IM) i Nordslesvig, og her var det et ufravigeligt princip, at ingen af dem, som bar ansvaret for det offentlige arbejde, måtte give sig af med politik. Sådan som IM dengang var sammensat, af helt modsatte folkelige bestanddele, var den nødt til at iagttage den pinligste neutralitet. ${ }^{44}$

Den halve snes år, som nu fulgte, blev så rig på kampe og lidelser, 
på begivenheder, oplevelser, omskiftelser med sorger og glæder, som jeg ikke havde tænkt eller anet, og det til trods for at hjemlivet gik sin gang uden den ringeste forstyrrelse. Det vil næsten overgå min evne nu at nedskrive det alt sammen og få det med under den rette belysning. Thi jeg har ikke siddet som en upartisk tilskuer, men har stridt ved fronten, dér hvor jeg havde fået min plads.

De to sogne, som blev mig betroede, havde en ret stor udstrækning. Fra øst til vest et par mil. Den største by, stationsbyen Vojens, havde et kapel og lå syv-otte km fra præstegården i Magstrup. En stor part af byens beboere var tyske embedsmænd, og denne tysktalende del af menigheden betjentes af sognepræsten i Hammelev, som prædikede på tysk i kapellet en gang om måneden. Jeg fik altså kun arbejdet iblandt de danske familier i Vojens - heldigvis. Men som sognepræst for det hele kom jeg dog i berøring med de tyskere, som var medlemmer af menighedens repræsentation, og dette førte ved lejlighed til konflikter. I det gamle Jegerup Sogn, bondesognet, såvel som i Magstrup Sogn fik jeg ikke særlige vanskeligheder at kæmpe med, ud over den rigtignok meget store åndelige sløvhed, navnlig i Jegerup.

Nogle år senere blev sognene delte, således at Vojens fik en præst og blev et selvstændigt sogn, mens Jegerup med sin gamle sognekirke gik som anneks fra Magstrup til Vojens, hvilket var det daværende repræsentantskab (menighedsråd) imod. Jeg beholdt så Magstrup alene, men har dog under krigen såvel som senere måttet besørge arbejdet i Jegerup med. I Vojens fandt man på at klage over mig til konsistoriet, fordi jeg tillod en indremissionær at tale fra prædikestolen i kapellet. Jeg fik en irettesættelse med omgåede påbud om at lade sligt være. En af de velkendte, for ikke at sige berygtede krigerforeninger, klagede i en længere skrivelse til mig selv over, at jeg ved en begravelse, hvor militærmusikken og krigerforeningen var med, havde lagt en vis ringeagt for dagen, idet jeg bl.a. var gået bort fra graven, mens musikken endnu spillede. Jeg svarede ikke, men tvivler ikke om, at der var gjort forsøg på at ramme mig ad anden vej. Det meste af dette fremmede og utiltalende element er nu forsvundet som dug for solen. Gid vi aldrig må se dem igen.

Ellers var det ikke arbejdet hjemme i sognene, som kom til at volde mig særligt besvær og uro. Men allerede inden jeg forflyttedes, havde jeg begyndt et fast medarbejde i Kirkelig Forening for Indre Mission i Nordslesvig, idet jeg var optaget i et nyt udvalg, som kaldtes det litterære udvalg, som skulle tage sig af hele IM's litterære virksom- 
hed, navnlig levere stof til blade, almanakker o.a. skrifter. Og dette udvalg, som hovedsagelig bestod af yngre mænd, blev en medvirkende årsag til store brydninger inden for foreningen. Jeg fik min rigelige part af alt det, som fulgte efter. Det drejer sig her om et stykke af Sønderjyllands åndelige historie.

Det var i og for sig til tider brydsomt nok at stå som præst af IM's støbning under de daværende forhold. Mange præster så skævt til os. Men rundt omkring i landet fandtes der kredse, som kaldte på os til at holde møder i deres hjem og missionshuse. Mange gange kom man til stede og erfarede, at mødet var arrangeret uden mindste hensyntagen til sognepræsten. Deraf kom fortrædelighed, bitterhed, klager. Mange gange har jeg og andre måttet underkaste os tiltale fra konsistoriets side. En enkelt gang fik jeg i sidste øjeblik telegrafisk meddelelse fra konsistoriet: Vi forbyder Dem at tale osv. ${ }^{45}$ Men alt dette kunne med lethed bæres, så længe vi var en sluttet enhed, der stod trofast sammen i god forståelse.

Det blev først til en lidelse, ja en nød dengang der kom splittelse iblandt os selv i IM. Ved flere lejligheder og på flere steder har jeg efter Genforeningen været bedt om at gøre rede for disse forhold, ligesom jeg har omtalt dem i Kristeligt Dagblad, i bogen Eben-Ezer og sidst i min bog Slesvigske Præster. Her skal jeg holde mig mere til min egen deltagelse i begivenhederne. ${ }^{46}$

I 1911, da jeg kom til Nordslesvig, havde IM bestået i godt en snes år, og man beredte sig til at fejre det første jubilæum. Formanden, pastor H. Tonnesen i Hoptrup, stod endnu i sin fulde kraft. ${ }^{47}$ En mindre sten med påskriften Eben-Ezer påtænktes rejst uden for missionshuset i Hoptrup, hvorfra IM gennem en lang række år havde modtaget sine stærkeste impulser. Mange årsager, forekommer det mig, blev samvirkende og medvirkende til, at de dage, som skulle fylde sindene med taknemlig erindring om Herrens store nåde og velsignelse gennem 25 år, blev til en mørk tid, med sorg og strid, ængstelse og splittelse, hvis eftervirkninger vi sporer den dag i dag.

Det må vel siges at være et kritisk øjeblik for enhver bevægelse, når den er vokset gennem en menneskealder, selv om krisen ofte kan drive over eller bæres over ved en stærk personlighed, uden at der mærkedes noget til den. Bevægelsen er da ved at glide over på andre hænder. Et nyt slægtled er mødt frem, som ikke har været med i grundlæggerarbejdet og nu skal overtage det hele som arv. Da har vi med det samme modsætningen mellem ung og gammel. Men ikke 
nok med det. En bevægelse, som var i sund vækst så længe, er blevet til en magt. Den er groet ind i det menneskelige samfund. Ikke den enkelte alene skal tage stilling til den, og ikke den enkelte alene skal dens tilhængere tage stilling til. Bevægelsen er blevet en bestemt og klar, mere eller mindre organiseret åndsretning, som vil gøre sig gældende i menneskelivet $i$ al almindelighed, i det offentlige, i det nationale, i tidens brogede og mangfoldige gøremål, den vil efter evne sætte sit præg på det livssyn, som slægten tilegner sig. Kort sagt, den vil indvirke på folkeorganismen, den vil bevæge masserne. Sådan med IM. Den begyndte i de dage ikke blot at virke som en magt, men også at føle sig som en magt. Men dette er måske det farligste øjeblik, som en åndelig bevægelse kan møde. Thi da trænger nye bevæggrunde og nye drivkræfter sig frem, og hvad der oprindeligt var rent åndeligt og med den styrke, som ligger i den indre ubesmittethed, vragede alt, hvad der var det jomfruelige unge åndsliv fremmed, det bliver nu vidsynet, føler sig stærkere over for det rent verdslige, bliver salomonisk i sin dom i modsætning til den forrige ensidighed. I IM's første tid var der noget, man kaldte den hellige ensidighed. Det var den, man stod i fare for at miste.

Her var det, at lederen ikke var på sin post. Han manglede pludselig kraft og helstøbthed til at bevare i det indre ukrænket, hvad han selv havde været med til at skabe og vække. Det unge præsteskab, som meldte sig til tjeneste, fuld af iver og lyst til at tage fat, troede, at en god del af den gamle metode var forældet. Det urokkelige krav om omvendelse, missionens blivende Schibolet, ${ }^{48}$ måtte efter deres skøn gøres noget elastisk. Ordet kunne gerne blive det samme, men indholdet måtte fornyes - eller omvendt, de vidste ikke så nøje hvad. Lignende med den hellige skrift. Den måtte gerne blive stående i menighedens bevidsthed som en af Gud selv indblæst og autoriseret bog, de ønskede ikke at oplyse menigmand om noget andet, men for deres eget vedkommende så de ikke i bibelen en fejlfri bog, de så historisk på den, som man ser på andre bøger. Dette kunne ikke andet end vække de ældre præsters mistillid og sorg, og mistilliden bredte sig hurtigt til videre kredse.

Et andet moment kom til. Det hørte med til vækkelsesbevægelsens overgang fra første til andet slægtled, at synet på det folkelige, nationale spørgsmål, som på det almenmenneskelige, borgerlige i det hele, begyndte at udvide sig. Man mente, at den kristelige ånd som en surdej måtte gennemtrænge alle forhold. For de gamle var folkesagen 
i Slesvig politik, og politik var djævelens værk. Ingen hellig burde røre derved med en finger. Iblandt den yngre slægt var der nogle, som mente, at en kristen i Nordslesvig havde ret til også at være en dansk mand, ja han havde pligt til at være det. Man gik et skridt videre og hævdede, at danske mennesker måtte bekende deres danskhed, og at det var en af Gud selv os pålagt pligt at stå ved vort folks side i den hårde kamp for tilværelsen. Mange kristne mænd og kvinder fra danske hjem havde tid efter anden opdaget, at kravet om neutralitet lød særlig stærkt over for danskerne, men ikke med den samme styrke over for tyskerne. Alle de, der prædikede denne lære præsterne - var tysksindede, talte tysk i deres hjem, sendte deres børn på tyske skoler, bad for den tyske kejser, ønskede tyskheden fremgang. Dette kunne nu være, hvad det var. Men de samme præster, som med hellig iver og rystende alvor tordnede mod al deltagelse i folkets kamp, særligt fra dansk side, tav helt stille, i hvert fald i offentligheden, over for de dybtgående retskrænkelser og den grænseløse magtanvendelse imod et værgeløst folk, som regeringen og dens embedsmænd øvede hver dag.

Den eneste gerning, som disse præster havde at fremvise for offentligheden, var den støtte, de ydede andragendet fra synoderne om danske sprogtimer i skolen, noget de så roligt kunne gøre, da de vidste på forhånd, at statsregeringen aldrig ville indlade sig derpå. Ellers lod de tyskheden arbejde uhindret, aldrig har man hørt af deres mund, at tysk politik var djævelskab. Først i den allersidste tid oprettedes en tysk fredsforening, hvis tanke, ord og gerning slugtes af Verdenskrigen. De tyske præster, som levede i Nordslesvig indtil Genforeningen, vil for størsteparten hævde, at de aldrig har befattet sig med politik, aldrig har taget parti i den store kamp. Som en af dem under en drøftelse udtrykte sig: Vi har på dette område været de rene børn. Sandt nok - på en måde. De vidste jo alle sammen såre vel, at de kunne medvirke til at neddæmpe lidenskaben hos folket, slukke den nationale ild i hjerterne, så skulle det germanske rovdyr i al ro og mag nok besørge resten. Hele den hjemmetyske del af IM fulgte disse præsters snilde råd. Og over for den danske part lød dagens tekst uforandret: Man bør være øvrigheden underdanig.

Men da de danske mennesker også inden for IM's kredse begyndte at se faren og forstod, hvor vi drev hen, da kom den nationale spænding med ind i de samme rækker, hvor ung og gammel stredes med hinanden om det religiøse livssyn. Der var en tid nogle mellemmænd, 
som forsøgte at forlige, men det ville ikke gå. IM skiltes en dag i to dele. Det faldt ikke i min lod, hverken at skille eller dele, men det blev, tør jeg nok sige, mig, der kom til at bære en stor part af byrden og måske den største part af smerten ved dette brud.

Ved en forhandling i Vojens angående det jubilæumsskrift, som skulle udgives i anledning af foreningens 25-årige beståen, erklærede jeg, at jeg for min part i mit indlæg agtede at holde på de gamle stier. Under det mig tildelte emne, »Hvad vi vil«, mente jeg at måtte betone, at vi i det dybeste ikke ville andet, end hvad IM ville ved dens oprettelse. Jeg ville særligt betone, at grunden, vi stod på, var nøjagtigt den samme, nemlig bibelen som Guds ord i enfoldig gammeldags forstand. Efter mødet stod et par af de yngre præster over for mig, og en af dem erklærede, at hvis det, jeg havde udtalt, virkelig skulle stå ved magt, ville man sprænge IM. Den unge mand overvurderede aldeles sig selv og sine venner. De var ikke i stand til at sprænge IM. Men jeg var endnu ikke helt fortrolig med tilstandene og lod mig kyse. På ingen måde ville jeg have taget ansvaret for at have hidført en sådan krise. Jeg trådte derfor tilbage fra medarbejdet ved dette skrift. Emnet blev slet ikke behandlet.

Fra den dag begyndte egentlig opløsningen. Vel havde der i forvejen været spænding og drøftelse, særligt i Flensborg under et præstemøde, men da havde man talt sig til rette og var ikke kommet bort fra det fælles åndelige grundlag. Efter mødet i Vojens blev det $\mathrm{i}$ det mindste mig klart, at der var noget i IM, som man måtte gå udenom, hvis ikke arbejdet skulle gå i stykker. Der var en skjult revne i bygningen, som i øjeblikket ikke syntes at kunne afhjælpes og i fremtiden sikkert ikke ville forblive skjult.

Jeg må bekende min skyld fra de dage. Det står nu aldeles fast for mig, at det urokkelige skriftgrundlag burde have været hævdet, sådan som jeg tænkte og foreslog. Jeg burde ikke i en ubegrundet ængstelighed have kastet den svære opgave fra mig. Alt ville være blevet anderledes, hvis der klart og tydeligt var blevet tonet rent flag, og et redeligt enten-eller var blevet sat på dagsordenen. Men mere endnu beklager jeg formandens optræden. Han burde have set og forstået, hvad det drejede sig om: at være eller ikke være. Enten måtte IM være det, den oprindeligt var: en profetisk bevægelse ud fra det uforfalskede og uantastede Guds ord - eller den var ikke mere. Vel påstod han ved lejlighed, at der med ham selv ingen forandring var sket. Hans stilling til bibelen var nøjagtig den samme som for 25 år 
siden. Det var vel sandt nok, men i virkeligheden tog han hensyn til den nye teologi, som havde en tilhænger i hans egen søn. Han vovede ikke af hensyn til de unge, hvis friske evner han satte megen pris på, at håndhæve de gamle principper, som han dog for sin egen person ville anerkende.

Mere og mere er det i eftertiden gået op for mig, at her lå ulykken og brøden. Jeg selv gjorde i alt, hvad jeg talte og skrev, stærkere og stærkere de gamle evangeliske toner gældende, men da var det for den gamle IM for sent. Den kunne ikke hjælpes mere. Formanden blev mere og mere holdningsløs. Alle klare linjer var udviskede. Iblandt de unge fortrød en og anden, hvad de havde gjort, men det var nu sket. Arbejdets styrke lå herefter mere end før hos de mange fortræffelige lægprædikanter, som forblev tro imod den gamle sammenslutning.

Måske ville folkekampen have bragt sprængningen med sig alligevel. Jeg ved det ikke. Man har påstået, at det var den, som i det hele var afgørende under krisen. Det afgørende var den efter mit skøn næppe. Havde der været tryghed og gensidig tillid med hensyn til de religiøse spørgsmål, så var man vel kommet til rette om dansk og tysk. Hos en mand som ungdomssekretæren Jes Kylling ${ }^{49}$ var dog begge dele forenede $\mathrm{i}$ en stædig danskhed og et friere syn på den kristelige forkyndelse blandt ungdommen. Jeg selv hørte efter mit teologiske standpunkt hjemme blandt modstanderne, men for mig var unægtelig det nationale afgørende, for så vidt som jeg ikke fandt nogen grund til at forlade det parti, hvori de fleste dansksindede sad. Men omvendt må jeg sige, at jeg næppe ville have forladt et samfund af overvejende tysksindede for min danskheds skyld. Langt mindre kan man sige om de øvrige præster, at den nationale tanke var vejvisende for dem. Vi beholdt på vor side ikke en eneste dansksindet præst foruden mig. Blandt missionærerne så det anderledes ud. Her trådte de nationale skillelinjer ret tydeligt frem. I selve splittelsens øjeblik gik kun en eneste dansksindet missionær med det tyske mindretal. Her var man mest tilbøjelig til at se på det hele som et nationalt opgør. Ude i befolkningen derimod blev linjerne igen mere forvirrede, idet mange af de dansksindede havde en så dybtgående kærlighed og tillid til enkelte af de præster, der skilte sig ud, at de ikke formåede at slippe dem.

Selve splittelsen 1912 foregik på den måde, at en kreds af præster, som til dels havde stået i forgrunden inden for IM i Nordslesvig, 
gennem en offentlig erklæring i dagbladene trådte ud af samarbejdet og dannede en ny organisation under betegnelsen »Det gamle Budskabs Indre Mission«. Til denne nye forening blev mit forhold fuldstændig negativt og afvisende. De tolv præster, som gik i spidsen, udførte en gerning, som efter mit skøn ikke kunne forsvares. Kun mænd af tysk karakter og tænkemåde kunne gå så let og hensynsløst hen over de smertelige følger, et sådant brud måtte få. Ingen af dem har nogensinde udtalt nogen beklagelse i den henseende, ingen af dem har vist modtagelighed for forsonende tanker. Spliden gik dybt. Det lå i sagens natur, at medarbejdere på begge sider ikke kunne være fælles om arbejdet. De kunne ikke tale ved et og samme møde, ikke benytte et lokale, som var præget af den modsatte retning. Mange samfund kom i indre vanskeligheder.

Idet jeg gentager, at det, der adskilte præsterne, egentlig ikke var det nationale - næsten alle præsterne var tysksindede - vil jeg dog indrømme, at man med nogen ret kunne tale om en dansk og en tysk IM, for så vidt som det danske element overvejende blev i den gamle, og det tyske overvejende sluttede sig til den nye organisation. At der lå et nationalt opgør bagved, vil ikke kunne nægtes, hvad så end de tyske præster mente og tænkte. I tidens løb måtte de nationale skillelinjer blive fremherskende.

En tid efter afholdtes provstisynoderne i landet. ${ }^{50}$ På den haderslevske synode tilbød den danske gruppe pastor Tonnesen at vælge ham ind i provinssynoden. Mens kampbulderet i IM gik gennem hele landet, havde de danske nordslesvigere lagt mærke til hans person, og udenforstående, som de fleste var, fandt de intet andet kriterium, end at han måtte være dansk eller i det mindste danskernes ven $\mathrm{i}$ modsætning til de udtrædende præster. H. Tonnesen var dog for klog til at modtage tilbuddet, idet han mente, at en af de gamle tyske præster kunne udrette mere for den danske sag end han. Da man alligevel holdt på ham, spurgte han: Hvorfor? Fordi vi ønsker at give Dem et tillidsvotum i denne tid. Det har jeg ikke behov, svarede den gamle.

Ak, han havde mere behov end det. Hint øjeblik var næsten tragisk. Der sad IM's gamle stoute formand, der havde stået så mangen gang i ilden og trodset mange angreb fra oven og fra neden, og vidste ikke, hvor dårlig hans sag nu stod. Guds ånd var veget fra ham. Og da vi gik ind i salen og stemmerne samledes om mig, viste det sig, at vi danskere manglede en eneste stemme for at have flertal og for at 
kunne sætte vore kandidater igennem. Tyskerne havde i forvejen dannet en fast blok, præster og lægfolk af alle afskygninger, og resultatet var forud vel beregnet. Ved første valgomgang kom et af de tyske medlemmer af vanvare til at stemme dansk. Efter optællingen af stemmerne løftede formanden, den tyske provst, forundret hovedet og udtalte, at der måtte foreligge en fejltagelse. Der blev talt igen, men resultatet blev det samme.

Men ved alle følgende afstemninger arbejdede apparatet upåklageligt. Det danske flertal var gået tabt på Haderslev synode, som det allerede var tabt i Tønder, Aabenraa og Sønderborg. Det skal slås fast, at alle tyske præster, med undtagelse af Tonnesen, gik med til denne akt, også de præster inden for IM, som altid havde betonet deres neutralitet i nationale og politiske sager, og som på ingen måde ville indrømme, at noget tyskeri kunne spille med under den sørgelige splittelse. Når det gjaldt, stod de altså mand for mand i den tyske front. Det er godt, når man skal dømme om deres færd, at have visse kendsgerninger at holde sig til. Præster af Det gamle Budskabs IM viste på Haderslev synode, at de ikke blot var tyske af sind, men at de agtede i kirkelige anliggender at gøre deres tyskhed gældende. De havde mod til at stemme tysk, mens de stod ansigt til ansigt med det valgte lægfolk fra deres egne menigheder. De gik sammen med det tyske mindretal af lægfolk for at underkue det danske flertal i deres sogne. Deres tyske samvittighed gjorde dem ikke opmærksom på nogen forseelse.

Det var en trist dag i Haderslev, da vi danske for første gang måtte bøje os for et unaturligt og uberettiget tysk flertal, men da sang tyskheden i Slesvig på sit sidste vers, hvad den da ikke vidste. Der er sket meget siden den tid, og mange ting glemmes i lykkens glade dage. Men der er et og andet i fortiden, som Danmark for sin egen skyld ikke bør glemme. Tyskerne har levet på løgn og magt i Slesvig, og magt og løgn formår over for et lille land mere, end man tror.

Efter at IM i Nordslesvig var delt i to, kom jeg til at bære en god del af byrderne i den gamle forening. Formanden beholdt selv sin plads i bestyrelsen og redigerede bladet Sxdekornet, som hurtigt fra ca. 6.000 holdere sank ned til det halve. Men næsten alt det øvrige arbejde kom til at hvile på mig. Redaktøren af det lille børneblad, som udkom hver 14.dag, løb sin vej over i den anden lejr, og jeg måtte tage bladet, som først var i sin fremvækst, på mig. Så længe det blev ved med at udkomme, har jeg søgt gennem det at have lidt berøring 
med Nordslesvigs børn og deres forældre. Tit har jeg selv bekostet illustrationerne. Det lykkedes i det mindste at fastholde en trofast læserkreds. Fra tid til anden lod jeg børnene skrive små stile, som jeg præmierede, en øvelse i modersmålet for dem, der lærte lidet eller intet deraf i skolerne. Også ungdomsarbejdet var i sin opvækst. Lederen, en præst, betænkte sig et øjeblik, men løb så samme vej som alle de andre. ${ }^{51}$ Derved fik jeg sæde i IM's bestyrelse. Senere, da de unges sekretær blev indkaldt i krigen, måtte jeg overtage ungdomsbladets redaktion, og til sidst fik jeg almanakken i tilgift. Da den hidtidige næstformand ${ }^{52}$ blev træt af den lidet attråværdige stilling og åbenbart kededes ved hele arbejdet, blev jeg sat på hans plads og fik dermed et vist medansvar for ledelsen af det hele IM-arbejde.

Så kom krigen og gjorde det hele mange gange vanskeligere, end det var i forvejen, gjorde det dobbelt vanskeligt for mig, som var bekendt for at være en dansk mand, dvs. en mistænkelig person. Meget havde splittelsen i vore rækker ødelagt. Den ene forening efter den anden havde meldt sig ud af fællesforbundet for KFUM og K. Kritikken og mistænkeliggørelen blomstrede offentligt og endnu mere i det skjulte. En præst sydpå skrev om en satans synagoge og sigtede dermed til os. ${ }^{53}$ Men krigen slog nye sår. Med et slag standsede hele børnearbejdet, idet man ikke vovede at samle børnene til møder og fester. De unge mænd i KFUM forsvandt med rivende hast, de fleste til fronterne, nogle over den danske grænse. Med tiden blev alle vore ungdomssekretærer indkaldt, ${ }^{54}$ med de mandlige medlemmer i fællesforbundets bestyrelse gik det ligeså. Indremissionærerne var ældre, men de fleste af dem måtte også af sted. Så sad formanden og jeg tilbage med nogle få indremissionærer og en kreds af unge præster, som nød mindre og mindre tillid ud over landet. Med vor pen og mund måtte vi være yderst forsigtige.

En lille tid lod jeg mine to beskedne blade udgå, i stilhed som hidtil, og jeg lod, som om jeg intet vidste om censur. Men da bogtrykkeren omsider også måtte med i krigen, og dagbladet Modersmålets trykkeri, som selvfølgelig var underkastet daglig censur, overtog mine blade, kunne jeg ikke mere undgå min skæbne. Med børnebladet gik det godt. Men i de unges blad optog jeg gerne breve og bidrag fra felten. Alt dette stof måtte først indleveres til censuren i tysk oversættelse, først til Haderslev og derfra til generalkommandoen i Altona. Ikke nok med at censuren da satte tykke røde streger over hele partier, men arbejdet blev yderligere besværliggjort ved vanskelighe- 
der og trusler og mundtlige forhandlinger på det haderslevske kontor. Dog holdt jeg det gående uden afbrydelse og uden alt for store indrømmelser. En komité i Haderslev, som udsendte danske kristelige blade til soldaterne i felten, udsendte også de unges blad i 1.500 ekspl.

Foruden dette bladarbejde kunne vi årligt i januar måned afholde et bibelkursus for de unge, og på himmelfartsdagen samledes efter gammel skik flere tusinde mennesker til store ungdomsmøder. Vor Frue kirke i Haderslev har ved de tyske præsters imødekommenhed flere gange genlydt af vore sange.

Da det hovedsagelig var præsterne, som havde voldt os al fortræd, opstod iblandt lægfolket tanken om en slags selvhjælp eller selvværn, en kristelig folkeorganisation imod det præstelige enevælde. Det var gode mænd, som satte sig i spidsen og dannede Kirkeligt Lægforbund i Nordslesvig. ${ }^{55}$ Men deres indflydelse nåede foreløbig ikke langt, folket fulgte dem ikke. Det gik med denne bevægelse som med frimenighedsbevægelsen, der ligeledes var båret af menigmand i modsætning til statskirke og præsteskab. Der var ingen grøde i dem. Sognekirke og sognepræst, selvom den sidste var nok så tysksindet, havde så dybe og stærke rødder i folket, at en bevægelse imod dem på forhånd var dømt til at mislykkes.

Lægmandsforbundet havde hele min sympati, jeg støttede det, hvor jeg kunne, men jeg så snart, at dets tid endnu ikke var kommet. Under krigen standsede det af sig selv. Hvorledes fremtiden ville have artet sig i denne henseende, er ikke nemt at sige. Tænker man på bornholmerne, ${ }^{56}$ som næsten udelukkende arbejder med lægmænd, måtte der sikkert kunne udrettes lignende ting i IM. Jeg skulle tro, at en dansk missionsbevægelse på folkekirkens grund i Sønderjylland kunne have fundet vejen til at frugtbart samarbejde med Luthersk Missionsforening. Også frimenigheden kunne vel ved lejlighed have ladet sig befrugte heraf. Men dette er nu ørkesløse tankeøvelser, som fredsslutningen i Versailles gjorde overflødige.

Aldrig har jeg villet slippe det håb og den overbevisning, at selvom hele præsteskabet blev os utro, så måtte der nedefra kunne gro et kraftigt og sundt kristenliv op på den danske folkegrund i Slesvig, et kristenliv og kirkeliv, som havde samme nationale værdi som frimenigheden, men som tillige havde den sejrende religiøse kraft, som alle vegne er ejendommelig for IM. Men da måtte der skæres igennem og renses ud endnu en gang, det følte vi mere og mere. Med undtagelse af mig selv ville ikke en eneste af vore præster gå med os til vejs 


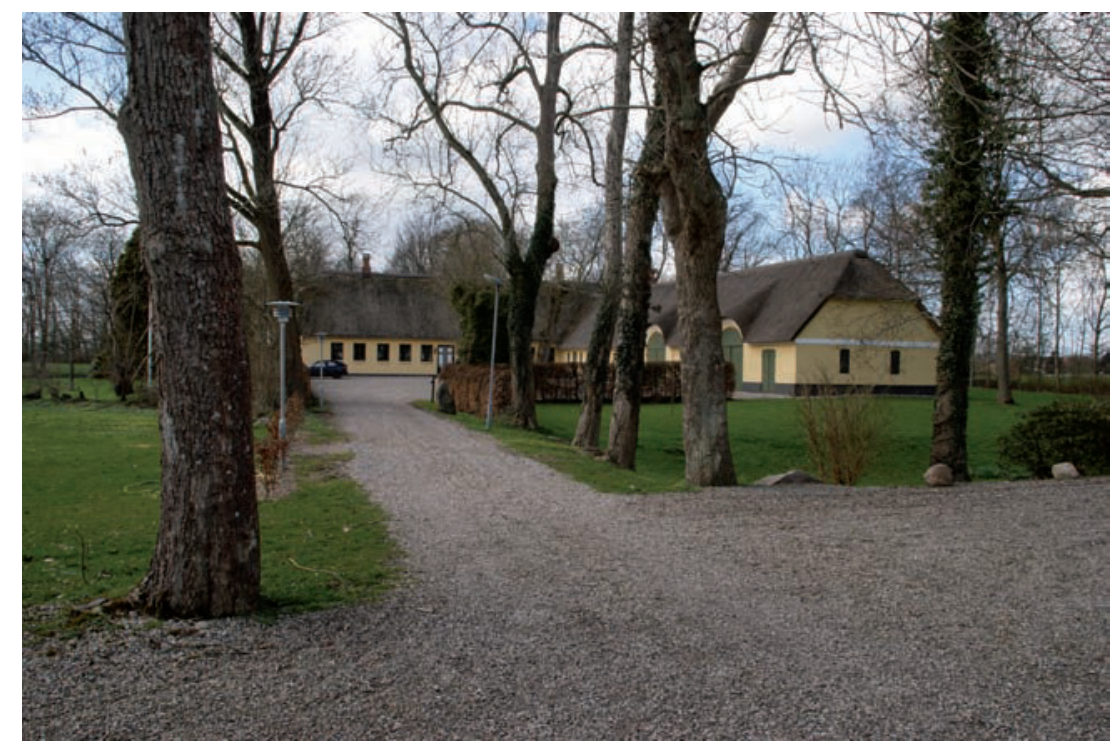

Magstrup præstegård, bygget 1813 på samme sted som den tidligere præstegård. Den mest kendte præst er Peder Jensen Wandal, som Carsten Petersen biograferede i 1924, »et Præsteliv $i$ det syttende Aarhundrede". Wandal mindes for sit berømte tårn $i$ præstegårdshaven, hvor han i fred og ro skrev bøger til sin samtid. 1659 omkom han og hans familie ved pesten i kølvandet på svenske og polske tropper. Foto: Jens Bruun.

ende. Krigen talte her et tydeligt sprog. Men netop krigen hindrede os også i at drage de sidste konsekvenser. Der var dem på begge sider af kløften, som i krigens afslutning med sejr eller nederlag for Tyskland så den eneste udvej ud af uføret.

Dette er nu sket. Men den kalk, som blev os i skænket, navnlig i krigsårene, blev besk at drikke. En stund var trykket næsten uudholdeligt for hjerte og nerver. Mange gange har jeg lagt mig i min seng om aftenen med det ønske: Gid du aldrig mere skulle stå op. Min kraft blev brudt i de dage.

Inden for sognenes grænser gik det daglige arbejde sin gang. I mobiliseringsdagene var alle sind dybt bevægede. Mænd, som skulle bort, ønskede at gå til alters først med deres hustruer. I det ydre fornægtede folket ikke sin karakter. Alt gik roligt fra akt til akt. Ingen i mine sogne tænkte på at løbe fra deres tunge pligt. Inden vi så os om, var de første af vore mænd i ilden, og fra Belgien kom det første dødsbudskab. Så begyndte vi at opsøge navne på landkortet, at finde 
bevægelsens retning, at skønne over farten og styrken i fremmarchen. Indtil slaget ved Marne. Da rejste der sig som en brænding i mange sind. Jeg fik kun lidt søvn den næste nat. Ikke alle, men dog en og anden mærkede, at nu blev terningerne kastede. Var Preussen skudt i hjertet? Ville ørnen løfte sig igen? I uger var de tyske sejrsmeldinger gået hen over vort land, med få dages mellemrum vajede flagene ved skoler og stationer. Organisten i Magstrup spillede for at give sit tyske hjerte luft - han var ellers af dansk familie - ved gudstjenestens slutning melodien: Wir treten zum Beten eller: Jesus giv sejer. På udflugt med børnene kunne han undervejs samle dem til storm mod Sedan eller andre franske fæstninger. Det er ham nu tilgivet alt sammen.

Fra felten modtog vi, indtil Marneslaget, meddelelser fra vore folk om den hurtige fremrykning. Ved juletid kom de nok hjem igen. Min egen bror skrev et kort fra Nordfrankrig: Hvis det bliver ved at gå som hidindtil, er vi om otte dage i Paris, og så får vi fred. Men så kom Marnedagene. Min hustru har været i Vejle hos slægtninge og fået fat i nogle danske aviser, som hun skjulte under sit tøj over grænsen. En del tabte hun, men af resten kunne jeg tydeligt forstå, at der var sket noget. Hvad betød nu Liege og Maubeuge og slaget ved Masurerne?

For mig bragte disse dage og den følgende tid en dobbelt oplevelse. Jeg blev langsomt klar over den verdenshistoriske franske dåd, og jeg begyndte at nære tvivl om de tyske beretningers pålidelighed. Fra den tid er Frankrig steget jævnt og sikkert, og Tyskland dalet lige så bestandigt i mit omdømme. Jeg har aldrig været en ven af tyskerne, men det var blevet min tro, at disse mennesker med deres gennemorganiserede militærmagt og det tilsvarende kvantum rå vilje ville være enhver modstander overlegen, i det mindste under det første berusende stormløb. $\mathrm{Nu}$ forstår jeg, at det franske folk i opofrende selvhengivelse og storslået tapperhed er det tyske overlegent. Moltke den ældre og den yngre, Ludendorff, Mackensee og Hindenburg med deres krigsteknik, Wilhelm II og Bismarck med deres statskunst og Tirpitz med sine undervandsbåde kunne ikke bestå i længden. Der er større, ædlere og dybere, mere menneskelige og åndelige faktorer, som bringer den endelige sejr hjem. Som det tyvende århundredes skønneste syn rejser sig det franske folks lyse helteskikkelse op over engelsk realisme og tysk selvforgudelse. Endnu en gang må Europa med agtelse og beundring bøje hovedet for den store nation.

Tyskland: Det begyndte med den hæderlige generalkvartermester v. 
Steins forsikring om, at folket skulle få sandheden at vide hele vejen igennem; det endte med, at en af de mest hæderlige og fædrelandssindede mænd i den tyske rigsdag med krampegråd i halsen råbte: Belogen und betrogen! ${ }^{57} \mathrm{Og}$ skylregnen faldt, og floderne kom, og vindene blæste og stødte an mod dette hus, og det faldt, og dets fald var stort. ${ }^{58}$

Og dog. Når vi ser tilbage, vi som i et halvt århundrede hørte til dette hus, vi har en følelse som rytteren, der var redet over Bodensøen. Hvad kunne der ikke være sket, og hvad ville der ikke være sket, dersom det havde varet halvtreds år endnu? Vi tænker på Sydslesvig og Flensborg, vi tænker på de gamle danske provinser hinsides Øresund. Tabt er tabt. Vil Dannevirke nogensinde kunne genvindes? Og Skåne? Moderne danske mænd smiler. De, der har stået i striden i to menneskealdre og set deres eget folk bukke under hver dag, mens magten ødelagde og kuede sind og vilje, hus og arv, de smiler ikke.

I Magstrup Sogn var der ingen, som kom til at tåle særlige forfølgelser under krigen. Et par gårdmænd blev i de allerførste dage hentede af gendarmen og sat $i$ arrest til den næste dag. De kunne have haft godt af at sidde der lidt længere. Den ene af dem skrev flittigt ansøgninger om at måtte blive hjemme på gården på grund af familieforhold, og man lod ham sidde i fred.

I min embedsgerning mødte der mig heller ikke særlige vanskeligheder med undtagelse af kirkebønnen, som jo skulle tage hensyn til krigen og sluttede med bøn om en ærefuld fred. Jeg forsøgte at føje mig i det uundgåelige, idet jeg tænkt, at enhver under en ærefuld afslutning af krigen kunne forstå, hvad han ville. Virkeligt blev de slagne tropper ved hjemkomsten til Berlin hilst velkommen som de »ubesejrede«. Hvis jeg kunne have tænkt på en sådan ærefuld afslutning, så kunne jeg af hjertet have bedt den befalede bøn. Men i det givne øjeblik skurrede ordene slemt i mine egne øren, og jeg ændrede udtrykket til »en ærlig fred «. En lørdag aften, da jeg sad ved min prædiken, mødte en kone fra nabolaget, en hjemmetyskers hustru, men for øvrigt af dansk slægt, og begærede at tale med min hustru. Hun ville sige hende, at jeg var blevet angivet, og at en kriminalbetjent ville være til stede i kirken den næste dag. Hun kom for at lade os vide, at hun og hendes mand var uskyldige i angiveriet. Jeg ved, at det hemmelige politi også senere har ført kontrol med mig, men til nogen akt kom det ikke.

Fra tid til anden så jeg lejlighed til at smutte over grænsen. Adskillige gange er det sket uden de rigtige papirer. Efter en del forhand- 
linger lod gerne både tyske og danske mig slippe igennem. Bestikkelser blev på tysk side almindelige. En dansk kontorchef står mig i meget behagelig erindring. Han regerede på Vamdrup station og var en myndig herre, der ofte kunne anslå en prøjsisk tone. Men mod mig var han så imødekommende, som om jeg var en fyrstelig person. Engang fremviste jeg et gammel forslidt og udueligt grænsebevis og spurgte, om jeg kunne komme over på det? Det kan De godt, lød svaret. Stemplet blev hugget i med et dundrende slag, personen nikkede til mig med et smil, som sagde: Jeg kan gøre alt. Kommer De med en gammel avis, stempler jeg også den.

I det ydre forandrede min gerning sig derved, at Jegerup Sogn blev skilt fra og delt $i$ to. Der oprettedes et nyt præsteembede i Vojens, og Jegerup gik som annekssogn fra Magstrup til Vojens. Man har villet se tyske politiske hensigter bag ved denne sognedeling, idet tyskerne vel håbede at kunne tiltage sig magten i stationsbyen også på kirkeligt område og således få tallet på de tyske gudstjenester øget. Der forelå allerede udarbejdede tegninger til kirke og præstegård. Kirken i Vojens skulle have et dobbelttårn, et vidnesbyrd om sejr og kraft i det tyske Slesvig-Holsten. Ellers var byggeplanen fornuftig og god, og delingen af de to sogne i tre var kirkeligt aldeles nødvendigt. Desuden havde jeg ved min tiltræelelse gjort det til en udtrykkelig betingelse, at Jegerup og Vojens skulle skilles fra.

I krigstiden måtte jeg overtage Jegerup igen et halvt års tid, da den unge præst gik frivilligt med som sygepasser. ${ }^{59}$ Senere kom der jævnligt folk fra Jegerup så vel som Sommersted Sogn i Magstrup kirke, da deres egne tyske sognepræster ikke mødte tillid hos danske mennesker. Der var i Magstrup indtil begyndelsen af krigen et ret stærkt kirkebesøg. Ved mange gudstjenester var huset så nogenlunde fuldt. Men da flere og flere mænd måtte med i krigen, og kvinderne fik mere at tage vare på i hjemmene, da den første sjælelige bevægelse tilmed ebbede ud, og mange sind både hjemme og i felten blev sløje, pessimistiske eller ligeglade, for ikke at sige forhærdede i åndelig skepticisme, da svandt også besøget ved gudstjenester og møder en del. Den tanke, som vel flere præster har haft, at vore mænd, når de kom tilbage fra det trælsomme og åndsdræbende liv, ville med deres familier fylde Guds hus, og at der ville komme ligesom en stor sabbatsstemning over folket efter den lange lidelse, slog fejl.

De mænd, som kom hjem fra fronterne og etaperne, blev ikke flittige kirkegængere. Enkelte, som i felten havde læst deres bibel og 
bedt deres bøn, trådte ikke mere over kirkens tærskel. Dog samledes snart nogle unge på ny for at genoptage KFUM's afbrudte arbejde. De sidste medlemmer var mod slutningen af krigen gået over grænsen. De, der nu trådte ind i rækkerne igen, har en efter en holdt foredrag i foreningen om deres oplevelser. Under de fleste af disse timelange foredrag har jeg dog undret mig over, hvor fattigt det åndelige udbytte af de mange oplevelser tilsyneladende har været. Rigtig nok må man huske, at unge mennesker ikke altid reflekterer over de ting, som møder dem, og heller ikke fører bog over, hvad de enkelte begivenheder kan have givet $\mathrm{i}$ nettoudbytte for deres indre liv. Allermindst har de tænkt på, at de kunne komme til at gøre rede for det $\mathrm{i}$ et foredrag herhjemme. En vis ubehjælpsomhed og mangel på $ø$ øelse i at gøre rede for tanker og følelser har vel afholdt en og anden fra at sige det, som han ellers tænkte at ville sige. Derimod har nogle af vore rejsesekretærer og indremissionærer, altså mænd med en vis rutine både $i$ at iagttage og meddele, givet os mange indblik i forhold og foreteelser under krigen, også i noget af den såkaldte krigspsykose, som vi længtes efter at få besked om. ${ }^{60}$

\section{Genforeningstiden}

Splittelsen i IM og krigen var de to store begivenheder, som kom til at præge mit liv i Magstrup. Den tredje var Genforeningen. Det falder svært nu bagefter at samle alle de minder og indtryk, som denne tid bragte med sig.

Fra Marneslaget til våbenstilstanden var der en lang tid med håb og frygt, og da Tyskland endelig brød sammen, var det endnu uvist, hvad fremtiden ville bringe os. Men omsider fik vi udsigt til at komme med i den store europæiske omregulering. Den nordslesvigske rigsdagsmand spillede sin sørgelige rolle og skuffede den tillid, som man dog mente at måtte have til ham i så afgørende et øjeblik. De fleste i landet så vel ikke skarpt nok til at forstå, at fejlen hos manden var en karakterfejl, og at hans politik i virkeligheden hele tiden havde været en omstændighedspolitik i modsætning til Jens Jessens samvittighedspolitik. Men mange følte det som en sorg og skam, at vi i det skæbnesvangre historiske øjeblik ikke havde en anden og bedre mand til at varetage Slesvigs ret.

Jeg skal ikke tage de forskellige grænselinjer og folkets mening om dem op til debat. Efter mit eget skøn ligger Slesvigs og Danmarks 
rette grænse ved Ejderen. Hertil går Danmarks ret. Skulle noget ofres af Danmarks gamle jord, kunne der kun blive tale om at gå tilbage til Dannevirke. Men nu er loddene faldne anderledes, mine to første sogne ligger på den anden side af grænsen - for mig en underlig tanke. Gud give, at det, som mennesker således har adskilt, må forenes igen trods alle magter og al stumpet statskløgt. ${ }^{61}$

I første zone blev afstemningsdagen noget, som vi aldrig før har kendt, og som vi heller aldrig vil komme til at opleve herefter. Alle hjemmene i sognet var fyldte med gæster, som var kommet fra nord og syd for at afgive deres stemme. Flagstænger var rejste ved alle huse. Præstegården havde også fået sit flag. Det var skænket præsten af en vennekreds i Haderslev ved afslutningen af en række møder (bibelfortolkninger, som var holdt på missionshotellet i krigsårene). Flagstangen skænkede de kirkeældste. Som formand for ungdomsforbundet i Nordslesvig modtog jeg for resten mange flag til uddeling $\mathrm{i}$ foreningerne. KFUM og K i Magstrup modtog naturligvis hver sit.

Egentlig burde de nye flag ikke hejses før genforeningsdagen, men så længe kunne mange ikke vente. Endnu lå dog den tyske militærbesætning langs grænsen. Da jeg ved en sammenkomst i Skodborgskov havde holdt min tale, og vi sad en glad kreds omkring kaffebordet, mens Dannebrog vajede lystigt i haven, blev husets ejer kaldt ud; der var militær udenfor, som ønskede at tale med ham. Vi kom på benene alle sammen. Rigtigt, der stod en lille trop tyske soldater med det krav, at flaget skulle tages ned. Da det ikke straks skete, holdt føreren sit gevær frem og spændte hanen. Hvad der skete, husker jeg ikke, men man kom fra det uden blodsudgydelse. For os danske ville det have været en let sag at tumle den klat tyskere.

Men på afstemningsdagen, da den internationale kommission sad i Flensborg, fløj de fleste flag til tops. Mange måtte bøde for det - idet vejret blev så ublidt, at nogle sønderreves af stormen, andre fløj helt bort, mens regnen på enkelte piskede farverne mellem hinanden. Under afstemningshøjtideligheden måtte jeg deltage i arbejdet, mere end jeg ellers havde tilbøjelighed til, især da ingen af lærerne i sognet kunne bruges ved denne lejlighed. Om morgenen måtte jeg møde ved skolen i Magstrup for med børnene at synge en sang og bede en bøn, mens flaget blev hejst. Der var ikke stort udvalg af danske sange. Vi blev enige om at synge »Aleneste Gud i Himmerig «.

Om formiddagen var der gudstjeneste i kirken, ved hvilken jeg naturligvis holdt prædiken. Vore gæster modtog ved bortgangen den 
i anledning af Genforeningen udkomne bog Mit Land. ${ }^{62} \mathrm{Om}$ aftenen var jeg bedt om at indlede samværet i Magstrup kro, hvor beboerne med deres gæster fik tiden til at gå med tale og sang, mens afstemningsresultatet gjordes op. Næste dag skulle der festes med børnene. Jeg måtte da være til stede igen og måtte fortælle noget om dronning Margrethe. Atter kneb det svært med sange. Kan I: »Der er et yndigt land «? Almindelig hovedrysten. »Jeg elsker de grønne lunde«? Hovedrysten. Så sang vi »Lover den Herre« og til sidst igen »Aleneste Gud i Himmerig«.

Under den følgende tids kamp for anden zone måtte jeg som præst holde mig tilbage. Embedsmændene var det forbudt at tage del i agitationen. Alt hvad jeg fik gjort, var at skrive et par breve til enkelte mænd i Brarup Sogn. Men fra Flensborg modtog jeg en forespørgsel, om jeg kunne tænke mig, hvis byen blev dansk, at overtage stillingen som provst?

Det var mig i høj grad tvivlsomt, om jeg på grund af mit udpræget danske sindelag var egnet til denne post? Jeg bad derfor mine venner i Flensborg om at samles med mig en dag for at drøfte sagen. Det var formanden for Kirkeligt Samfund, bankdirektør Thomsen, som havde henvendt sig til mig, og i hans hus var jeg taget ind som gæst. ${ }^{63}$ Mens jeg sad og talte med fruen op på formiddagen, kom direktøren op fra banken med et brev i hånden. Det er da underligt, sagde han, her får jeg lige et brev, som sætter mig i stor forbavselse. Det er fra stiftsprovst Hoffmeyer i København, jeg kender ham slet ikke - at det dog skulle komme lige i dette øjeblik! Direktøren satte sig ned med en kendelig forsagt mine. $\mathrm{Og}$ så læste han brevet, i hvilket stiftsprovsten meddelte, at han i tilfælde af, at Flensborg blev dansk, var udset til provst. Han betonede, at sagen var definitivt afgjort og håbede, at denne afgørelse måtte blive til gavn og glæde og gensidig velsignelse. Jeg har aldrig omtalt denne sag til stiftsprovst Hoffmeyer, da jeg senere omgikkes ham hver dag, og også han tav. Men det er åbenbart, at han har fået nys om, hvad der var i gære, og derefter skyndt sig at forhindre videre ulykke. ${ }^{64}$

Ved mødet med mine venner blev brevet oplæst. De fleste syntes ikke om den københavnske fremgangsmåde, at man så ganske uden at spørge de danske på stedet havde lagt det hele til rette $\mathrm{i}$ al stilhed. Pinligt var det, men efter hvad man senere har set, meget vel stemmende med adskilligt andet, der blev budt den slesvigske befolkning i genforeningstiden. En bitterhed blev tilbage hos mange. Det flens- 
borgske spørgsmål ordnede sig af sig selv. Hverken Hoffmeyer eller jeg blev provst der.

Efter afstemningen kom genforeningsdagen og den danske konges besøg. Mens en fremmed præst holdt gudstjeneste i Magstrup (efter mit eget ønske) viste mit forrige annekssogn Jegerup mig den ære at lade mig holde gudstjenesten der. Om aftenen talte jeg på missionshotellet i Haderslev. ${ }^{65}$ Med kongens indtog havde jeg intet at bestille så lidt som nogen anden af de indfødte præster i landet. Vi så det syn, at Danmarks konge ved grænsen blev modtaget og hilst på sønderjydernes vegne af en provst, der var sendt over fra Sjælland. ${ }^{66}$ Der blev prædiket fra Frue kirkes prædikestol i Haderslev af en biskop, der var sendt fra Ribe, og i koret pyntede flere danske biskopper og præster, mens kirkens egne præster og andre fra omegnen sad ukendte og ubemærkede rundt om i kirken. Senere havde vi lov til, når de kongelige for rundt i landet, at stå ved en grøftekant og vente, indtil der muligvis gjordes holdt ved vejen. Og når man som jeg ikke indfandt sig ved grøftekanten, blev det vel endda taget unådigt op.

Men det er småting. Vi har sagt os det mange gange, at vi ville hjem til vort folk, selv om der skulle møde os adskilligt af skuffelser under og efter denne hjemfærd. Skuffelsernes tid er ikke forbi, vi møder dagligt noget dansk, som er os underligt imod, men det skal ikke tage det minde fra os, et af de største vi ejer, om den dag, da vi festklædte og båret af højtidsstemning gik hen for at stemme på Danmark. Sjældent har vi - mange af os aldrig - været løftet sådan op over tid og rum som i hint øjeblik. Derfor vil guldet i dagens billede heller aldrig miste sin glans. Historien skal til alle tider mindes vor bedrift. Og historien skal vide, at vi ville gøre den samme bedrift om igen - trods alt.

\section{Genforeningstidens kirkelige udvalg}

Ved Nordslesvigs indlemmelse i Danmark måtte en hel række kirkelige sager komme til offentlig forhandling og fremkalde nye love og forordninger. ${ }^{67}$ For at få det forberedende arbejde gjort nedsatte Nordslesvigsk Vælgerforening, sikkert efter tilskyndelse fra København, et kirkeligt udvalg i lighed med og ved siden af andre udvalg. Jeg kunne ikke anse denne fremgangsmåde for heldig. Allerede i princippet måtte den i høj grad misbilliges, idet nemlig vælgerforeningen var en politisk sammenslutning, den eneste rent politiske for- 
ening i Nordslesvig. Men det var netop en gammel og stående klage hernede, at de tyske politiske foreninger blandede sig i kirkelige sager. Ikke bedre blev det derved, at udvalgets sammensætning kun i ringe grad svarede til sagens og opgavens beskaffenhed. Det er nok her at bemærke, at formand blev en mand, som hørte til frimenigheden, altså stod uden for folkekirken. ${ }^{68}$ Denne taktløshed kom endnu stærkere til syne, når man betænker, at folkekirken i Nordslesvig på det tidspunkt endnu havde sin egen selvvalgte repræsentation $\mathrm{i}$ provstisynoderne. Men hensigten var sikkert netop den: gennem vælgerforeningsudvalget $\mathrm{i}$ al stilhed at få den bestående kirkeforfatning begravet. Bagefter har en og anden af os forstået sammenhængen.

Mens disse forberedelser stod på, følte jeg mig tilskyndet til at forsøge at vække kirkefolket i landet og kalde ansvarlige mænd frem i menighederne, som kunne og ville tage sig af deres gamle kirke og ikke lade dens skæbne bero i en politisk forenings hænder. ${ }^{69}$ Men her led jeg en stor skuffelse. Kirkefolket i Nordslesvig sov. Ingen kendte noget til kirkepolitik. Alle var inderligt overbeviste om, at hvad vælgerforeningen gjorde måtte være velgjort, og bare vi blev danske, så ville alt være i den bedste orden. Min opfordring i offentligheden til at forsøge at få valgt et kirkeligt repræsentantskab, som med fuldmagt fra menigheden burde varetage de vigtige kirkelige interesser, fandt ikke den genklang i det stakkels forkludrede og åndsforkvaklede Nordslesvig, som det ville have fået f.eks. i det kirkepolitisk langt modnere Danmark. Da jeg med nogle venner, som havde stillet sig til rådighed, ville til at begynde et oplysningsarbejde ude i landet, måtte netop mange småbaner af kulmangel standse eller indskrænke driften. I samme øjeblik søgte det netop nedsatte udvalg forhandling med mig. Disse forhandlinger var forgæves, men førte til, at vælgerforeningen opfordrede mig til at tage sæde i udvalget, hvad jeg selvfølgelig nægtede.

At vælgerforeningen ikke blot var et slags mellemled mellem København og Nordslesvig i denne sag, som muligvis kun skulle hjælpe regeringen til at få et passende udvalg sat sammen, fremgår af, at dette udvalg indgav sin betænkning til vælgerforeningen, som forsynede teksten med sine egne randbemærkninger og sendte den videre i sit eget navn.

Så snart Nordslesvigs indlemmelse i Danmark var sket, skabtes der ved lov et udvalg for kirkelige anliggender med det formål at forberede 
de nye kirkelove, hvorved sammensmeltningen af den danske og nordslesvigske folkekirke skulle indledes. ${ }^{70}$ Det bestod af 39 medlemmer valgt efter forholdstal. For Nordslesvigs vedkommende valgtes kun præsterne (tre) ved skriftlig afstemning iblandt alle her ansatte præster, mens de øvrige medlemmer (fem) valgtes af de nyoprettede provstiudvalgs læge medlemmer. Sammen med provst Nissen i Haderslev ${ }^{71}$ og pastor Tonnesen i Hoptrup fik jeg sæde i dette udvalg. Mens de to førstnævnte blev valgt på en fællesliste af danske og tyske, IM og grundtvigske, kom jeg igennem på en særliste med udelukkende danske stillere. Når politisk interesse gør sig gældende, kan der ske mærkelige ting. De samme præster, som i sin tid vragede $\mathrm{H}$. Tonnesen og ikke kunne tale ved et og samme møde med nogen af hans mænd, gik nu i stor samdrægtighed med til at vælge ham som deres repræsentant i København; der var jo altid nogen tyskhed tilbage hos ham. De forstod i deres tyske klodsethed ikke, hvor lidet denne mand duede til dette hverv.

Efter at valget havde fundet sted, sammenkaldte provst Nissen formodentlig efter pastor Tonnesens tilskyndelse - alle sønderjyske medlemmer til et møde i Vojens for at få lejlighed til at lære hinanden at kende, før vi skulle til København. ${ }^{72}$ Det var et ganske overflødigt møde, som kun resulterede i en almindelig snakken om ting, vi ikke kunne tage nærmere stilling til. Men fra Tonnesens side forelå der et bestemt forslag, endda skriftligt udarbejdet i enkeltheder, som gik ud på, at vi hernedefra skulle danne en sønderjysk gruppe inden for udvalget. Dette var provst Nissen dog erfaren og forstandig nok til at afvise med et smil. Hvordan sagen ville have artet sig, hvis vi virkelig var optrådt enige og samlet i sluttet flok under afstemningerne derinde, er ikke godt at sige.

I det særlige arbejde har vi aldrig i fællesskab gjort et særligt sønderjysk standpunkt gældende. Tværtimod gik vi straks efter det konstituerende møde hver sin vej ud i de bestående danske grupper. Til den fælles gruppe af IM og Kirkeligt Centrum sluttede sig foruden mig pastor Tonnesen (efter tøven og med et halvt hjerte) og tre lægmænd, nemlig O. Olesen, ${ }^{73}$ Jacobsen og C. Michaelsen (hvilken sidste dårligt passede i båsen og i grunden ikke vidste, hvor han hørte hjemme). De øvrige tre medlemmer gik ind i den grundtvigske gruppe.

I tidens løb kom jeg ind i en hel række underudvalg; de vigtigste var forfatnings- og bispevalgsudvalget. Hvad jeg har kunnet udrette i de travle og anstrengende dage, ved jeg ikke, men jeg håber, at jeg ikke har siddet der uden at gøre gavn. Desværre blev provst Nissen 
og jeg mere og mere saglige modstandere. Det har uden tvivl været ham inderligt imod, at jeg sad ved hans side i forfatningsudvalget og stadig gjorde min opfattelse gældende, som faldt sammen med IM i Danmark og gik ham stik imod. Mange gange forsøgte han at finde en mellemvej mellem den radikale fløj og IM, og han var, som minister Appel engang spottende kaldte ham, den store fredsmægler. Men det lykkedes ikke, og da vi engang gik sammen ned ad trapperne, ytrede han med en vis bitterhed til mig: »Det er Deres skyld, pastor Petersen«. En mand derhjemme har engang sagt til mig: »Hvis provst Nissen kunne æde Dem, så gjorde han det«. Dog har der aldrig været personlige uoverensstemmelser imellem os. Men jeg følte godt, at det kunne være provsten ukært, når jeg ud fra mit indgående kendskab til tysk lovgivning og sønderjysk kirkeliv i en menneskealder ved lejlighed kunne tale med en vis vægt. Provsten var født sønderjyde, men glemte stundom, at han var en rømningsmand i den lange tid, da vi andre stod på skanserne. I udvalget led han mange nederlag og blev til tider træt og bitter.

Om udvalgets arbejde i sin helhed skal jeg ikke udtale mig. De mange lovudkast måtte bagefter gå gennem Rigsdagen og blev omarbejdede i enkelte vigtige punkter foruden i mange uvæsentlige. Men bagefter har jeg erkendt, at såre meget, navnlig i de økonomiske love, kun dårligt svarede til slesvigsk retsopfattelse. Og hvad der blev os klart straks ved udvalgets første fremtræden, både ved kommissoriets oplæsning og den drøftelse, der sluttede sig dertil, var det: at vor slesvig-holstenske kirkeforfatning en gang for alle var slået ihjel. Det havde regeringen i København sammen med Den nordslesvigske Vælgerforening besørget i overgangstiden. Vi stod simpelthen over for en fuldbyrdet kendsgerning. Der er ræve i Danmark og i Nordslesvig. ${ }^{74}$

Alligevel havde den tid, jeg sad i det kirkelige udvalg, for mig som for andre hernedefra en stor og uforglemmelig betydning. Jeg fik ikke blot sat mig ind i dansk lovgivning, dansk kirkepolitik og danske kirkelige forhold, men jeg sad en stund sammen med nogle af Danmarks bedste mænd. Lige over for mig ved bordet sad dagligt i en række: Professor Torm, ${ }^{75}$ stiftsprovst Ussing, redaktør Kjærsgård, professor Westergård ${ }^{76}$ og professor Oskar Andersen. ${ }^{77}$ Den betydeligste af dem og udvalgets bedste kraft var uden tvivl Ussing, den mand som jeg kunne have ønsket til Slesvigs første biskop..$^{78}$ Overretssagfører Hammershaimb ${ }^{79}$ blev min ven, og det er mig en dyb smerte, at 
han døde så tidligt, inden jeg fik lejlighed til at træde i nærmere personlig forbindelse med ham.

Samtidig med at jeg blev medlem af det udvalg, kom jeg ind i Haderslev provstiudvalg, valgt med et flertal, som grænsede til enstemmighed. ${ }^{80}$ Dette provstiudvalg bestod dog kun, indtil de nye kirkelove trådte i kraft. Det vigtigste, vi fik at gøre, var at præsentere præster til valg i en del af provstiets menigheder. Også her fik jeg desværre lejlighed til at gøre den erfaring om igen, at danske mænd, som var sendte til os nordfra, kunne bruge rævekunster, som vi andre ikke ville have brugt og ikke forstod os på at bruge. Og de mænd, om hvem dette måtte siges, var netop af den slags, som ved deres bedårende jævnhed vandt befolkningen, både små og store.

Genforeningen med Danmark bragte store forandringer med sig, skønt man fra alle sider var enige om, at disse forandringer måtte ske så lempeligt som muligt. Det første vi mødte, var de nye personligheder. Biskop G. Koch i Ribe måtte foretage den foreløbige bispegerning i de sønderjyske landsdele foruden sit eget store stift. H. Ussing udtalte engang, at denne mand var i sin tid Danmarks betydeligste biskop. Jyde var han og en kraftig person at se til. Men kraften var allerede brudt og blev det ved det overmål af arbejde og sorg, som han måtte bære. I det kirkelige udvalg var han formand i IM's og KC's gruppe. På den sønderjyske kirke kom han ikke til at øve nogen indflydelse af betydning. Han døde, før det første bispevalg blev udskrevet. Skønt jeg tror, at han så på mig med velvilje og havde tiltænkt mig stiftsprovsteembedet $\mathrm{i}$ Haderslev, kom jeg ikke i nogen egentlig personlig berøring med ham. Mens jeg var i Brarup, læste jeg hans bog om præst og menighed.

Iblandt provsterne, som sattes foreløbig til at bestyre i provstierne, var J. Gøtzsche i Rødding sikkert den betydeligste. ${ }^{81}$ Han var, som man sagde, bispeemne. Af den grund søgte nogle af præsterne inden for IM at formå mig til at opsøge ministeren I.C. Christensen og udtale det som et ønske fra Sønderjylland, om man måtte få den gode provst til biskop. Jeg var også i ministerens private lejlighed, et par almindeligt møblerede værelser i en eller anden gade, men ministeren var ikke hjemme. Han var, som værtinden udtrykte sig, nok stukket af til Jylland. Senere henholdt han sig til, at der nok ville blive lovgivet om bispevalg, hvilket han ikke ville foregribe.

Om provsten i Haderslev, J. Nissen, har jeg talt. Han var en ven af minister Appel. At disse mænd sammen med andre lavede rævestreger, når det passede dem, for at nå deres mål, er vistnok de fleste 
kyndige villige til at indrømme. Selv Appels venner i det kirkelige udvalg stolede ikke på ham. Provsten brugte et par gange list og snuhed på en måde, som ikke kastede et godt lys over hans karakter. Den ene gang drejede det sig om præstevalget i Sommersted. Hans grundtvigske ven, Hjortkær, ${ }^{82}$ skulle vælges. Men IM i sognet holdt på pastor Ørberg. Provstiudvalget skulle foretage præsentationen og havde det altså i sin hånd at give hr. Hjortkær sådanne medbejlere, som var lette at besejre. Det ville ellers muligvis blive en hård kamp. $\mathrm{Nu}$ kunne af hensyn til den stærke IM i Sommersted ikke godt dens kandidat sættes ud af spillet, det var heller ikke provstiudvalget oplagt til. Men hvad gjorde så provsten? Han tog frem af ansøgernes bunke pastor Bülows fra Marstal og erklærede: En sådan mand er vi nødt til at præsentere, jeg kender ham fra min ungdom, han er en af Danmarks bedste præster. Jeg selv kunne godt ønske pastor Bülow ${ }^{83}$ som min nabopræst, men det var klart, at hans opstilling måtte splitte IM's stemmer, og dette var selvfølgelig provstens mening. Jeg gjorde derfor opmærksom på, at hvis Bülow præsenteredes til valg, måtte han i hvert fald gøres opmærksom på, hvorledes sagerne stod. Ja, svarede provsten, naturligvis skriver jeg det til ham. Dermed slog jeg mig til ro. Men der er ingen tvivl om, at provsten forsømte at give pastor Bülow de tiltrængte oplysninger. Han fik dem imidlertid fra anden side og trak sig tilbage. Ved valget sejrede dog grundtvigianerne, og provstens list var for så vidt overflødig.

Den anden gang drejede det sig om provstens forbliven i embedet, da overgangstiden var udløbet. I det øjeblik skulle han have en anbefaling fra provstiudvalget, hvis formand han selv var. Provsten henstillede nu ikke til de øvrige fire medlemmer at forhandle den sag indbyrdes. Nej, han tog sagen frem, mens vi var i København. En dag kaldte han C. Michaelsen ${ }^{84}$ (hans gode ven) og mig hen på hotellet, hvor han boede, og gjorde os bekendt med, hvad han ønskede: en anbefaling. Han vendte sig så til C. Michaelsen: Vil De som den ældste føre det i pennen? Det ville den gode ven gerne. For at lette ham arbejdet, sagde provsten selv, hvorledes den skulle skrives, og Michaelsen skrev. Så var den sag klaret, provsten havde skrevet sin egen anbefaling. Dette var, hvad danske embedsmænd foretog sig over hele linjen. Ikke bogstaveligt at forstå, at de gjorde det så groft som J. Nissen. Men de kom, de satte sig, og de blev. Det var dem en torn i øjet, at så mange præster og lærere fra før forblev i embedet ved befolkningens afstemning. ${ }^{85}$ 
Også nye kirke- og menighedstanker, nye åndelige synspunkter og retninger, særlig grundtvigianismen, kom til os over den gamle grænse. Hele visitatsvæsenet hørte op og erstattedes af et hurtigt provstesyn, der havde ren revisionskarakter. Alle valg blev forholdstalsvalg, i hvilke også kvinderne deltog. Også et bispevalg - noget ganske nyt - kom vi til at deltage i. Den forudgående propaganda holdt jeg mig helt borte fra. Men ved afstemningen faldt vistnok de fleste stemmer i Magstrup på biskop Ammundsen, ${ }^{86}$ hvem også jeg stemte på. Grundtvigianerne havde den sorg og skuffelse, at deres kandidat, provst Nissen, døde før valget og erstattedes med provst Hjortkær, som ikke formåede at komme så stærkt i forgrunden, at ministeren, hvor gerne han end ville, kunne indstille ham.

Ligesom gennemførelsen af valgene gik ikrafttræelelsen af de øvrige love sin rolige gang. Både i Magstrup og rundt omkring begyndte en restaurering og udsmykning af kirkerne, hvorved dansk smag og dansk byggekunst gjorde sig gældende på en heldig og glædelig måde. ${ }^{87}$ Også ellers bredte sig med tiden dansk skik, f.eks. dåb i kirken i stedet for hjemmedåb. Så længe jeg havde været præst i Magstrup, havde jeg forsøgt at lempe dåben ind i kirken. Ca. halvparten skete dog endnu i hjemmet, særligt på gårdene, det var noget finere at lade sit barn døbe hjemme af en suppeterrin eller en sukkerskål. Der stilledes endog et offerbord frem til præst og degn, hvor hver modtog sit papir med et par småskillinger. Med Genforeningen var det herefter forbi, ikke et eneste barn begæredes hjemmedøbt. Med skolevæsenet havde præsten ikke noget mere at gøre. Da der anden gang skulle vælges skolekommission, blev jeg, ganske mod min vilje, sat ind på en særliste og var derefter formand for Magstrup skolekommission indtil min bortgang. I Sommersted kunne jeg ikke blive det, men afholdt efter opfordring hvert år skoleeksamen.

Om den tid jeg har siddet som præst i Magstrup, skal jeg endnu sige et par ord, navnlig med hensyn til mit private liv. Jeg har foretaget et par rejser til England, først til Edinburgh (ungdomsstævne KFUM) og så til Oxford (arbejde blandt de yngste, "amongst juniors«), begge gange fra Esbjerg over London. På disse rejser trådte jeg i forbindelse med China Inland Mission, hvilken forbindelse dog blev afbrudt ved krigen. Endvidere har jeg i de senere år berejst Tyskland, Schweiz, Italien, Sverige og Norge. I Danmark plejede jeg at gæste København og møderne på Nyborg Strand. Men jeg fik aldrig mit fædreland lært at kende, som jeg ville. ${ }^{88}$ 
I krigsårene nedskrev jeg et og andet af, hvad der gik gennem mit sind, i bundet stil, og udgav det som en genforeningsbog med titlen Mit Land. ${ }^{89}$ Nogle år senere fik jeg trykt en lille bog om Peder J. Wandall, præst i Magstrup og Jegerup 1627-59. ${ }^{90}$ Det lille arbejde har her i landet vundet megen anerkendelse, men blev dårligt solgt. Ellers standsede alt mit litterære småarbejde. Ved intet dagblad eller tidsskrift agtede jeg at være medarbejder. Til alle opfordringer om at tale ved møder i Danmark, som jeg ved Genforeningen modtog, sagde jeg nej. ${ }^{91}$ Samtidig bad jeg mig fri for at blive valgt ind i noget som helst udvalg eller bestyrelse. Kun Almindeligt dansk Præstekonvent overrumplede mig og satte mig ind i sin bestyrelse, første gang jeg mødte i konventet for at holde foredrag om sønderjyske kirkelige forhold. $\mathrm{Nu}$ er jeg ude af den igen.

Lejlighedsvis har jeg givet mig af med at granske i arkiverne, navnlig vedrørende forholdene i Haderslev Amt. Det var min tanke at få udgivet en samling aktstykker til amtets historie, desuden en beskrivelse af Magstrup Sogn o.s.v. En stor del af mit livs arbejde har været med pennen. Uventet ( $\mathrm{i}$ anledning af udmærkelse med ridderkorset) kom den opgave til mig at nedskrive mit levnedsløb, noget som jeg aldrig har haft tilbøjelighed til. Arbejdet blev gjort, og jeg var glad, da besværet var overstået. ${ }^{92}$ At det blev noget vidtløftigt, mente jeg efter gjorte erfaringer at måtte begrunde med, at det, der i eftertiden sættes mest pris på, ofte er de beskedne enkeltheder, mens det tørre skelet af et menneskeliv ikke vil interessere nogen. Det, som den levende anså for ringe og ubetydeligt, ikke egnet til at optegne, har ofte givet historikeren, som hørte den anden tid til, den største berigelse.

Når jeg undslog mig fra alt udensogns arbejde, ${ }^{93}$ var det ikke blot ulyst til at farte omkring og være med i tidens travlhed, men også et svigtende helbred, som gjorde sig gældende. Nogle rejser til Bad Nauheim ${ }^{94}$ forfriskede og styrkede hjertet for en tid, men ikke i længden. Jeg måtte tænke på min afsked. Biskoppen holdt igen: Når De ikke kan gøre arbejdet i Magstrup, hvad kan De så? Nej, netop derfor ville jeg gå. Jeg tog omsider beslutningen uden at spørge nogen. På min indsendte ansøgning gav Kirkeministeriet det svar, at jeg måtte betænke mig et par måneder; hvis jeg efter den tid opretholdt min begæring, skulle den blive forelagt kongen. Til den 1. april 1932 fik jeg så min afsked. V. Ammundsen sad i kirken under min sidste prædiken og spiste til middag hos os. Al festlighed, foræringer og sligt havde jeg frabedt mig, og vi begrundede dette med, at vi få år i for- 


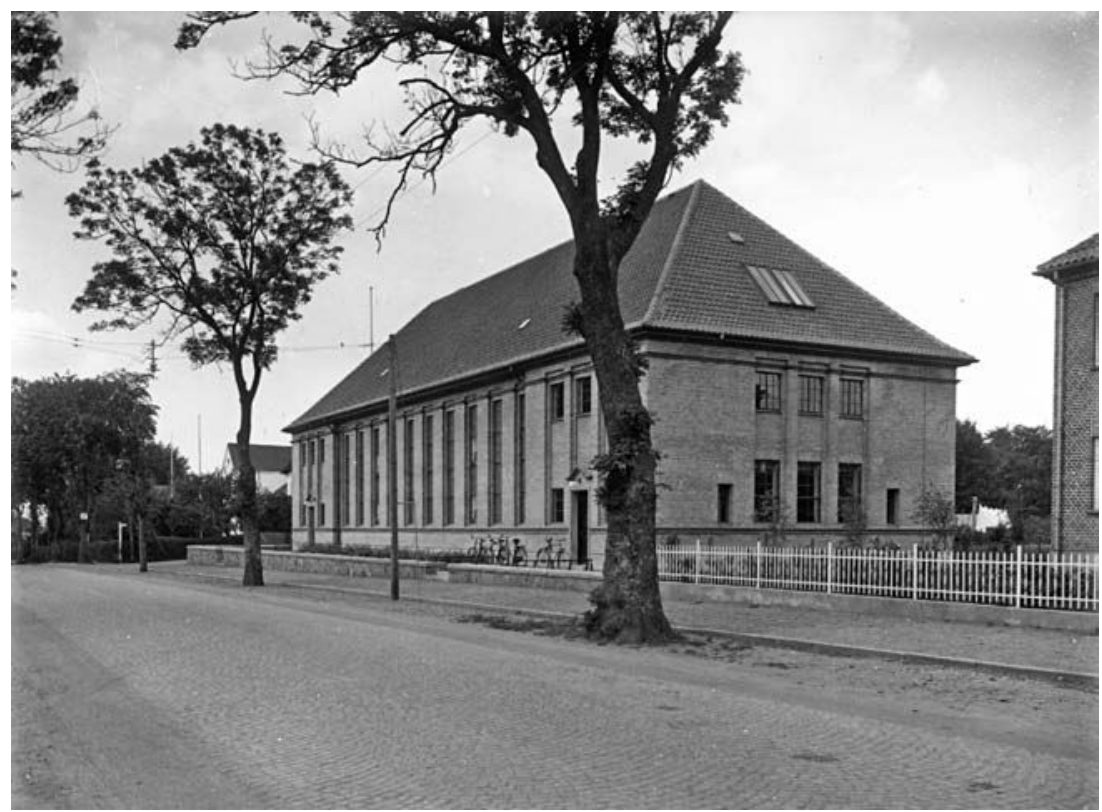

På Haderslevvej, tidligere Nørre Chaussé, i Aabenraa ligger Landsarkivet, hvor Carsten Petersen som pastor emeritus fik sin daglige gang fra 1932 til sin død, resulterende $i$ en del historiske afhandlinger og det store samleværk Slesvigske Præster, baseret på et kvalificeret arbejde med vanskeligt tilgængelige kilder. Foto: Museum Sønderjylland - ISL.

vejen i anledning af vort sølvbryllup havde modtaget gaver fra sognets beboere. Vi slap for en gentagelse af disse intetsigende opmærksomheder.

\section{Pastor emeritus fra 1932}

For mine historiske studiers skyld var jeg interesseret i det nyoprettede landsarkiv. Da det kom til at ligge i Aabenraa, foretrak jeg at bo i nærheden og slog mig ned i Stubbæk. ${ }^{95}$ Fra dansk side gik man straks efter Genforeningen i gang med Sønderjyllands historie, tyskerne fulgte efter. Indvandrede danske præster skrev landsdelens kirke- og præstehistorie, mens landets børn tav. Da følte jeg det som en opgave, ja som et kald, at tage mig af denne historie, skønt jeg ingenlunde har villet navn af historiker. Det bares mig for, at jeg som en af de ældste og sidste af den bortsvindende slægt, som en endnu 
levende medvider, burde aflægge vidnesbyrd for de kommende slægter om, hvad jeg har set og hørt. Og ikke blot dette, men den kirke, jeg havde tjent $\mathrm{i}$ en menneskealder, kunne vel gøre krav på de kræfter, der endnu var i behold. Den kunne vel også gøre krav på en tak for den lykke, glæde og ære, den havde bevist mig ved at betro mig kald og menighed, både i den tyske og danske tid, både iblandt tyske og danske mennesker.

Min opmærksomhed dvælede ved præstegårdene. En historisk beskrivelse af disse gamle kulturcentre eksisterede for Sønderjyllands vedkommende ikke. Men idet jeg gik til kilderne for at søge og samle stof, blev jeg mere og mere overbevist om, at en skildring af gårdene ikke kunne gives, uden at der måtte tales om deres beboere og dem, der havde skabt og plantet alt det skønne, der omgiver vore præstegårde. Altså præsterne.

En regelret præstehistorie var allerede under udgivelse og interesserede mig kun lidt. Jeg valgte at skrive præstestandens fælleshistorie ned gennem tiderne eller, som jeg kaldte den, et udsnit af denne historie. Arbejdet var vidtløftigt nok, særlig da det var mig imod at drøfte min sag og mine hensigter med andre eller søge stof ud over de offentlige arkiver. Uden at nogen kyndig eller ukyndig fik lov at snakke med, udførte jeg dette arbejde i løbet af fem-seks år. Bogen blev trykt i Tønder, midt i min hjemegn, på min egen bekostning og sendt ud til alle præsteembeder i Sønderjylland og desuden til nogle biblioteker og enkelte private personer. Underligt nok var der mennesker, som på offentlighedens vegne følte sig dybt krænkede ved denne fremgangsmåde. Publikum tåler ikke en sådan tilsidesættelse. ${ }^{96}$

En del småafhandlinger blev trykt i Sønderjyske Arbøger, deriblandt en beskrivelse af kirkerne i Haderslev Provsti efter Reformationen. Da jeg i årenes løb havde samlet kildestof til flere provstier, besluttede jeg at udføre dette arbejde, endnu inden jeg dør. Manuskriptet blev groft færdigt, omfattende de øvrige provstier, og bliver efterhånden trykt. ${ }^{97}$ 


\section{KILDER OG LITTERATUR}

\section{Utrykte kilder}

Landsarkivet i Aabenraa:

Carsten Petersens privatarkiv (CP's arkiv).

\section{Skrifter af Carsten Petersen:}

Rejsemåltid: en meget kort Andagtsbog for Unge. 1911.

Mit Land. 1919.

Peder J. Wandal: et Præsteliv $i$ det syttende Aarhundrede. 1924.

Slesvigske Præster: Et Udsnit af Præstestandens Historie. 1938.

Slesvigske Landsbykirker gennem 300 Aar. 1941 (særtryk af artikler i Sønderjyske Årbøger 1931-1941).

»Kirker i Sønderborg Provsti«, Sønderjyske Årbøger 1942, s. 161-199.

»Slesvigske Præstegårde«, udgivet posthumt i Sønderjyske Årbøger 1946, s. 231-298.

\section{Øvrig litteratur:}

Ammundsen, Valdemar: »Det aandelige Liv«, Sønderjyllands Historie: fremstillet for det danske Folk, bd. V, 1933, s. 307-410.

von Bassi, Hasko: Otto Baumgarten: Ein "moderner Theologe "im Kaiserreich und in der Weimarer Republik, 1988.

Dansk Biografisk Leksikon, 3. udg., bd. 5, 1980 (DBL).

Favrholdt, M.: Haderslev Latinskoles historie, 1966.

Haderslev-Samfundets Årsskrift, div. årgange.

Henningsen, Lars N.: Kirke og folk $i$ grænselandet. Dansk kirke i Sydslesvig 1921-1996, 1996.

Henningsen, Lars N. og Johann Runge: Sprog og kirke. Dansk gudstjeneste $i$ Flensborg 1588-1921, 2006.

\section{NOTER}

1. Bertel Godt (1814-85), f. i Rinkenæs, præst i Rinkenæs, Notmark og Felsted, afsat 1850, præst i Hagen, Westfalen. I 1864 konstitueret i Broager, derefter valgt samme år som generalsuperintendent for Slesvig. DBL bd. 5, s. 231.
Holdt, Jens: » Fortegnelse over Pastor Carsten Petersens trykte Arbejder ", Sønderjyske Arbøger 1947, s. 228-29.

Holdt, Jens: »Carsten Petersen. En dansk-slesvigsk præst 1871-1943《, Sønderjyske Arbøger 1961, s. 6-79.

Holdt, Jens: »Hans Tonnesen. En nordslesvigsk præst 1854-1935 «, Sønderjyske Årbøger 1962, s. 101-141.

Høst, Lisbeth: Det Ene Fornødne. Nordslesvigsk Indre Mission og Det gamle Budskab 1880-1945, 1997.

Ingesmann, Per: »Da der gik kirkepolitik i Genforeningen", Sønderjyske Arbøger 1995, s. 239-60.

Jessen, C.C.: Biskop i Grænselandet. Theodor Kaftan 1847-1932, 2009.

Kirchen- und Schulblatt, div. årg.

Kronika, Jacob: Den sidste Slesviger og Ulsnæs-mordene, 1971.

Licht, Chr. de Fine: »Den nordslesvigske Vælgerforenings kirkeudvalg 1918-19«, Sønderjyske Årbøger 1984, s. 87-120.

Paulsen, H. Hejselbjerg (red.): Den nordslesvigske Kirke. Landsdelens Kirkeliv og Sognekirker. Skrevet af sønderjydske Præster, bd II, 1948.

Skrumsager, J.N.H.: Æt og Minder. Udgivet ved Hans-Ole Mørk, 2007.

Thyssen, A. Pontoppidan (udg.): Dansk Præste og Sognehistorie, bd. X, hefte 4, 1979.

Weitling, Günter: »Kirchliche Erweckung und nationaler Gedanke - die nordschleswigsche Erweckungsbewegung und ihre Nationalisierung ", Schleswig-HolsteinischeKirchengeschichte, bd. 5, 1989, s. 369-414.

Weitling, Günter: Geschichte der Kirche in Ost-Jeypore, 1998.

2. Hans Schlaikier Prahl (1845-1930), f. i Ø. Løgum, præst i Mjolden, Møgeltønder, Egen og 1893-1919 i Gl. Haderslev, 1919-26 præst for den tyske menighed sst. Den drivende kraft og sagkundskab bag såvel den slesvig- 
ske liturgi som salmebogen for de dansktalende menigheder fra 1888.

3. Carsten Petersen (CP) har beskrevet skoletiden i Haderslev i HaderslevSamfundets Årsskrift 1940, s. 7-18, "Da vi gamle gik i Skole".

4. Peter Hinrich Jessen, præstesøn fra Kværs, rektor 1864-1889, i katedralskolens endnu "slesvigske « periode, se Favrholdt 1966, bl.a. s. 232f, hvor fremstillingen bygger på CP's Slesvigske Præster, som Favrholdt karakteriser som en "imponerende bog ", og CP's korte erindringer i Haderslev-Samfundets Årsskrift 1940, s. 7-18, og 1947, s. 8-15.

5. Se Favrholdt 1966, s. 240. Ostendorf var rektor 1889-95.

6. Kortfattet omtale af Emma Petersen, f. 1870, d. 1943 få måneder efter sin mand. Ægteskabet var barnløst. CP beretter ikke meget om sit forhold til det andet køn. Breve i arkivet synes dog at antyde, at det ikke altid har været lige kedeligt.

7. Adolph von Harnack (1851-1930), banebrydende kirkehistoriker i Berlin med studier i oldkirken og den opsigtsvækkende bog Das Wesen des Christentums.

8. Julius Kaftan (1848-1926), f. i Løjt præstegård, bror til generalsuperintendent Theodor Kaftan. De to brødre er de kendteste kandidater fra Kiels Universitet. Julius K. satte sig på Schleiermachers lærestol i Berlin, det fornemste embede i den evangeliske teologiske verden.

9. Erlangen var stedet for den konservative, konfessionelle erfaringsteologi. Hertil kom mange teologer fra Nordslesvig, men også fra Danmark. Af disse omtales her Hans Tonnesen og Henry Ussing.

10. Heinrich Otto Baumgarten (18581934), professor i Kiel fra 1894 til 1928, liberal teolog, forkætret af den ortodokse kirkelighed og jævnligt i modsætning til biskop Kaftan. En præsteadresse krævede hans afgang i 1903, i stedet ansattes en ekstraordinær lærer i praktisk teologi. Aktiv modstander af det nye parti NSDAP og antisemitismen. Se hans biografi ved v. Bassi 1988. 2 postkort i CP's arkiv.
11. Albrecht Ritschl, professor theol. i Göttingen, det største navn i anden halvdel af det 19. årh.s teologi.

12. Theodor Kaftan (1847-1932), f. i Løjt, præst i Aabenraa 1871-79, regeringsråd i skoleanliggender 1880-86, generalsuperintendent 1886-1917, frimenighedspræst i Baden-Baden til 1926, død sst. Se om CP's opfattelse af Kaftan i Slesvigske Præster, se endvidere Jessen 2009.

13. I CP's arkiv findes en del breve, der giver indtryk af studenterlivet og tonen blandt de unge nordslesvigske teologer, f.eks. brevene fra Peder Simonsen (1870-1953), der senere blev en kendt skikkelse i IM. Trods divergenser forblev der en fri tone de to imellem også i alderdommen, hvor Simonsen flytter ind på Zeisesvej 19 i Haderslev.

14. At CP var savnet af studiekammerater af begge køn vidner et par breve om. 10.4.1898 meddeler således Hakon Refslund (1871-1954, senere amtslæge i Haderslev), at en lille flok agter sig til Møgeltønder Vesterkro og »i alle Damers Navn bedes du om at komme derud. Ellers risikerer $\mathrm{du}$, at vi gaar til Gallehus og brænder dit Hus af ...« Og ved eksamens lykkelige afslutning 1899 telegraferer Anna, Jacob og Thyra fra Haderslev: »Til Lykke. Du est en Knop!! Hurra!!« $\mathrm{CP}^{\prime}$ 's privatarkiv.

15. Praktisk teologisk uddannelse for teologer, som søgte embede i Nordslesvig. H.S. Prahl leder af den lille institution samtidig med sit embede i Gl. Haderslev.

16. Nicolai Christian Nielsen (18481932), præst og digter, formand for IM i Nordslesvig 1886-1907, præst 1873 i Højrup, 1888 i Sommersted, 1906 i Tandslet, 1911 i Bedsted, 1916 i Oksenvad. I livlig korrespondance med CP (CP's privatarkiv). Se Kronika 1971.

17. Dagbogen findes i CP's arkiv.

18. Nis Simon Gottfriedsen (1852-1927), præst i Nustrup og provst for Tørninglen Provsti 1892-1913.

19. Om $C P^{\prime}$ s embedstid i Flensborg se den grundige fremstilling i Henningsen og Runge 2006, s. 185-206. 
20. Hans Jürgen Carstens (1825-1903), præst ved Helligåndskirken 18691900, se Henningsen og Runge 2006, s. $174-76$.

21. Karl Niese (1853-1925) provst og førstepræst ved Mariekirken, også kaldet Frue kirke.

22. Johannes Lensch (1871-1942), præst for Sct. Jørgens menighed 1895-1934. Se Henningsen og Runge 2006, s. 215.

23. Se fremstilling af sagsforløbet i Henningsen og Runge 2006, s. 198-230.

24. Emil Wacker (1839-1913), præst i Rinkenæs 1867, rektor og præst for Diakonissestiftelsen i Flensborg 1876-1910. Den ledende skikkelse i den ortodoks-lutherske del af den slesvigske kirke med et omfattende teologisk og kirkeligt forfatterskab, se Jessen (2009). 1910 inviterer Wacker CP til at prædike ved den lutherske forenings konference, dermed var han godkendt fra højre.

25. Som mangeårig skrivende redaktør af dette blad udøvede Hugo Wurmb en betydelig indflydelse, ofte i forståelse med biskop Kaftan.

26. Friedrich Andersen (1860-1940), præst ved Sct.-Johanneskirken 18901928, fra 1895 redaktør af Kirchenund Schulblatt indtil hans omfattende værk Anticlericus 1907 satte en stopper for det. Andersen udviklede både kirkeligt og folkeligt stærkt højreradikale synspunkter og blev modstander af bekendelseskirken. 1937 æresborger i Flensborg.

27. Johannsen død 25.10.1901.

28. Efter flytningen en del breve fra taknemlige menighedsmedlemmer, der savner CP, f.eks. Anna Thomsen, der 11.5.1905 skriver: »vi taler så ofte om Dem og ønsker, at vi havde Dem i Flensborg, det er bedrøvet, sådan det har taget af med kirkebesøget."

29. H.F. Feilberg (1831-1921), præst og folkemindeforsker. I Sydslesvig 1859-64.

30. »Kirchliche Verein für Evangelisation « - stiftet 1909 på grund af ukirkeligheden i folket som en fri virksomhed til »Ergänzung der altgeordnete Amtsthätigkeit«, med Kaftans medvirken. Formand pastor
Jungclaussen, Sörup; i bestyrelsen Carl Matthiesen, Rødding, og professor Schaeder, se note 31. Medlemskort for $\mathrm{CP}$ og formålsbeskrivelse i CP's arkiv.

31. Artikler af CP i bladet 1905-11, bl.a. årsoversigter og kommentarer, "Rückblick" , under pseudonymet Spectator. I 1908 deltager han sammen med Kiel-professoren Schaeder og præsten Jürgen Braren i den heftige debat om Kaftans teologi, især dennes skrift Der Mittler (se Jessen 2009). Kaftan taber terræn til de ortodokse, og Emil Wacker står bag oprettelsen af en »Luthersk Forening « til værn mod uklarhed. CP's indlæg bærer præg af hans optagethed af Kierkegaard og vender sig konsekvent imod formidlingsteologien, som Kaftan synes at stà for.

32. Holdt anfører ikke artikler fra Sonntagsblatt, derimod fra Kristelig Folkekalender for Nordslesvig, udgivet af Breklum, og Nordslesvigsk Søndagsblad (tillæg til Flensborg Avis), Holdt 1947 , s. 232.

33. Kirchen- und Schulblatt 1909, s. 521f og 529f., gennemgår CP de danske kirkeforhold med særligt henblik på sognebåndsløsning, der debatteres i bladet, "Lockerung des Parochialbandes«. Om CP's kirkesyn henvises til ibd. s. 253, teser til den lutherske konference i Flensborg.

34. Van Wijk, præst og professor i Amsterdam, skriver 28.12.1909; bekendt med biskop Kaftan fra de lutherske konferencer.

35. Det mest kendte besøg var i sommeren 1912 af de to unge lovende teologer, C.I. Scharling, senere biskop i Ribe, og Holger Brøndsted; breve i $\mathrm{CP}^{\prime}$ 's arkiv. Brev fra Brøndsted, hvor han anmoder om opskriften på præstegårdens vidunderlige kvædebrød, CP's arkiv. To tyske teologer skulle ligeledes være kommet, den ene Eduard Asmussen fra Breklum, se Holdt 1961, s. 52.

36. Gabriel Koch (1858-1922), sognepræst i Herning 1889, biskop i Ribe 1901. Kst. biskop for de sønderjyske landsdele fra maj 1920 til sin død.

37. Centrum for mission og teologisk 
uddannelse siden 1876, oprettet og ledet af den karismatiske præst Christian Jensen til 1899. Arbejdede parallelt, men jævnligt i strid med den tilsvarende institution i Kropp under ledelse af Johannes Paulsen. Breklum var især kendt for sin mission i Jeypore i Indien, hvortil en del nordslesvigere blev udsendt som missionærer, helt til nutiden i samarbejde med Danmission, se Weitling 1998. CP opretholdt vedvarende forbindelse til nordslesvigeren Anders Andersen i Jeypore, ordineret som missionær 1912 af Kaftan. AA sender postkort fra verdensmissionskonferencen i Edinburgh august 1912 og julekort fra Kotapad 1913. 1939 foreslår provstinde Edith Flensmark, om ikke der kan sendes et eksemplar af Slesvigske Præster ud til AA, der nu er rejst ud igen.

38. Breve fra Kaftan i den anledning i $\mathrm{CP}^{\prime}$ s arkiv, refereret af Holdt 1961, s. 34. Også breve fra Gråstens sognepræst W. Steffen, der nærmest anså sagen for afgjort. Samt beklagende brev fra menigheden, der gerne havde set CP som deres præst.

39. Det var Ernst Günther, der i 1914 i landdagen rettede voldsomme angreb på præsternes og især Kaftans svage holdning i det nationale.

40. Prøveprædikenen »Aufstellungspredigt « i Gråsten foregik 27.11. 1910. Men allerede 15.11. får CP en henvendelse fra Magstrup om den forestående embedsledighed dér. Her blev der prøveprædiken mod Wassner, Hammelev, og Andersen, Moltrup - og CP's udnævnelse 16.6. 1911.

41. Die philosophische Weltanschauung Søren Kierkegaards, manus i $\mathrm{CP}^{\prime} \mathrm{s}$ arkiv.

42. Nordslesvigsk Søndagsblad 1910, Evangelische Kirchenzeitung 1911, se Holdt 1947, s. 232.

43. CP synes at tage fejl af årstallet, idet han refererer konferencen i Kirchenund Schulblatt 1906, s. 511-17.

44. Det er vigtigt at erindre, at den nordslesvigske IM fik et rent evangeliserende formål, i klar tilslutning til den folkekirkelige struktur og præ- sterne. Opgaver inden for diakoni og mission, der i Tyskland er det egentlige i »Innere Mission" iflg. stifteren J.H. Wichern, blev henvist til særlige foreninger, f.eks. Asylforeningen.

45. Holdt 1961, s. 52; politimyndighedens brev i CP's arkiv. Mødet skulle finde sted 30.6.1914 på »Hotel Stadt Hamburg « i Gråsten, der i skrivelsen karakteriseres som »dansk forsamlingshus «.

46. Se om hele krisen $\mathrm{CP}^{\prime}$ s gennemgang i Slesvigske Præster, aftrykt i Holdt 1961, s. 42-50, se endvidere Høst 1997 med oversigt over kilderne, og Weitling 1989.

47. Hans Tonnesen (1854-1935), IM's ledende skikkelse, redaktør af IM's organ Sædekornet og formand for foreningen fra 1907. Præst i Aabenraa 1880-88 og i Hoptrup 1888-1927. Se Holdt 1962.

48. Hebraisk: Løsen; nutidigt: adgangskode.

49. Jes M. Kylling (1873-1931), fra 1907 sekretær for »Fællesforbundet af Kristelige Ungdomsforeninger i Nordslesvig «.

50. Ved overgangen til preussisk styre blev der straks indledt et energisk arbejde med kirkens struktur og forfatning, resulterende i den såkaldte "Gemeindeordnung " fra 1869, med udgangspunkt i grundlovens bestemmelse om »kirkelig selvforvaltning «. 1876 fulgte den endelige »Kirchengemeinde- und Synodalordnung " med menighedsrepræsentationer (kirkeældste og kirkekollegier), provstisynoder og landskirkens fællessynode. Systemet sikrede den danske befolkningsdel taleret og medieindflydelse. Se f.eks. Skrumsager 2007, note 317.

51. Peder Simonsen (1870-1953), præst CP's gamle skole- og studiekammerat. Udtrådte af IM's bestyrelse september 1912 og som leder af ungdomsarbejdet.

52. Niels Schmidt (1874-1934), provst i Rødding 1911-19.

53. Formentlig den kendte ClausenTodenbüttel, redaktør af Die köstliche Perle, højreradikalt opbyggelses- 
blad. A.W. Hildebrandt fra Breklum henviser til bladet og de »beklagelige ytringer« $\mathrm{i}$ brev om $\mathrm{CP}^{\prime} \mathrm{s}$ fratræden som eksaminator ved Breklumseminariet, hvilket ligeledes beklages: »Hvorfor skal vi uskyldige lide under den usalige konflikt i Nordslesvig? « (brev i CP's arkiv).

54. J. Kylling, P. Paulsen og J. BørsenHansen.

55. April 1913, med J.M. Kylling som initiativtager; formand Iver B. Jensen. Oprettet som et muligt værn mod overgreb fra statsregimet i kirke- og skolesager og som støtteforening for mission og diakoni. KL fik ikke nogen lang levetid.

56. Luthersk Missionsforenings oprindelige populære betegnelse, hentydende til bevægelsens geografiske oprindelse.

57. Kunne være Mathias Erzberger (1875-1921), Centrums leder i Rigsdagen.

58. Matt. 7, slutningen.

59. Martin Bertheau, f. 1882, mistede sit embede i Vojens ved afstemningen 1920, se Thyssen 1979, s. 320.

60. I CP's arkiv en hel del postkort fra felten, især med tak for tilsendte kristelige blade, almanakker etc., f.eks. fra den senere provst og historiker Jens Holdt 13.12.1914.

61. Allerede 27.11.1918 skriver CP til præsten i Vamdrup, H.I.F.C. Matthiesen (senere ved Vor Frue i Haderslev): »ét synes os dog ikke at slå fejl mere, og det er, at Slesvig, - under opgivelse af Dannevirke for anden gang - vil slutte sig til sit moderland.« $\mathrm{CP}$ så ved den lykkelige forening af de kristelige ungdomsforeninger nord og syd for den daværende grænse en »missionstid « foran sig blandt unge og gamle, "som vi måske ikke har set magen til«. CP's arkiv.

CP's synspunkter lægges i perioden til Genforeningen frem, delvist anonymt, i artikler i Kristeligt Dagblad »fra vor kirkelige medarbejder i Sønderjylland «, i CP's arkiv korrespondance med Kristeligt Dagblads redaktør Ernst Kjærsgaard, som han senere møder i det kirkelige udvalg.
62. Mit Land (1919) - Sønderjyllands topografi og historie på vers, se Holdt 1961, s. 55. Bogen vandt stor udbredelse og mange reagerer med takkehilsener til CP. Den er indgået i den aktuelle grænsediskussion, C. Skovgaard-Petersen skriver således 20.2. 1920 i sin hjertelige tak: "Måtte Gud selv sætte grænsen, så vi må prise hans navn." I december takker KFUK i London for modtagelsen af 100 ekspl.

63. Peter Thomsen (1860-1922), direktør for Flensborg Folkebank. Formand for Kirkeligt Samfund fra 1912, se Henningsen 1996.

64. Henrik Hoffmeyer (1865-1924), sognepræst på Frederiksberg 1909, stiftsprovst 1910. Det ser ud til, at han gennem Kylling søger oplysende litteratur om grænselandet. Forespørgsel fra denne til CP 9.7.1919 (CP's arkiv).

65. I Haderslev Vor Frue (Mariekirken) talte Henry Ussing (1855-1943, præst ved Jesuskirken, Valby, stiftsprovst 1915-33 i København) ved både andagten 10. februar og takkegudstjenesten den 11 . Ussing var den mand, $\mathrm{CP}$ gerne havde set som Nordslesvigs biskop, og han fulgte vedvarende den sønderjyske sag. 1926 medvirker han ved Ansgarfesten i Flensborg. Fremtrædende medlem af kirkeudvalget 1921.

66. Det var Jørgen Nissen, der på dette tidspunkt blev konstitueret som provst i Haderslev Provsti, men formelt stadig var sognepræst i Vemmelev. Af brev fra Schultz, Ellehus, til pastor Peder Simonsen i Nr. Løgum ser det ud til, at Jørgen Nissen allerede i juni 1919 var udset til stiftsprovst $\mathrm{i}$ et nyt nordslesvigsk stift; derfor frarådes Simonsen at søge til Gl. Haderslev. Simonsens arkiv i Landsarkivet for Sønderjylland.

67. Se herom Licht 1984, den mest veldokumenterede fremstilling af det spegede spil omkring Genforeningen; ligeledes Ingesmann 1995.

68. Mads Gram, Københoved (18761952).

69. CP søgte sammenkaldt en kirkelig 
forsamling med henblik på at rådgive vælgerforeningens kirkelige udvalg, med følgende formulering: 1 . Der udpeges inden for folkekirkens tillidsmænd - en for hvert sogn som sammenkaldes til rådslagning $i$ sådanne sager, som Vælgerforeningens udvalg ikke af sig selv kan ordne. 2. Denne forsamling af kirkens tillidsmænd indkaldes ufortøvet, når adskillelse af stat og kirke proklameres. 3. Der udnævnes eller udpeges af tillidsmændenes kreds en bestyrelse på mindst tre personer, som får løbende indblik i de vigtigste forhandlinger inden for det af Vælgerforeningen nedsatte udvalg (håndskrevet dokument i CP's arkiv, publiceret i Dannevirke 24.12.1918). $\mathrm{CP}^{\prime}$ 's tanker støttes af Knud Rosendal, frimenighedspræst i Aabenraa 1910-20, senere konstitueret i Vojens 1920-23 (brev fra Aabenraa 17.12. 1918 i CP's arkiv og indlæg i Flensborg Avis 18.12.). Endvidere i kongeriget af den kendte kirkehistoriker $P$. Severinsen, redaktør af Kirke-Tidende, der løbende kommenterer udviklingen.

3.2.1919 skriver Mads Gram, at CP's forslag afvises af Vælgerforeningen, og at han i øvrigt stadig afventer svar fra $\mathrm{CP}$, om han indtræder $\mathrm{i}$ det kirkelige udvalg. Opfordringen fremsat telegrafisk 1.1.1919 fra »Aktionsudvalget « ved Martin Simonsen, Flovt, »efter fremsat ønske fra flere sider «. Det blev et nej. (CP's arkiv).

Fra flere sider, f.eks. sognepræsten M. Lauritzen i Varnæs (Flensborg Avis 3.2.1919), manede man til tilbageholdenhed med hensyn til CP's tanker om en fri folkekirke i Nordslesvig, og i stedet afvente en "ny tidssvarende fælles kirkeforfatning " i forening med den danske folkekirke. Ved Nyborgmødet 1919 taler CP om »Den åndelige stilling i den sønderjyske kirke«.

70. I skrivelse af 22.1.1921 beskriver I.C. Christensen det ved lov nedsatte udvalgs baggrund og opgaver. Udvalget arbejdede hele året, indtil IC i december erklærede »så lukker vi butikken « (CP's personlige referat). $\mathrm{CP}$ anfører i sin udførlige sammenfatning af udvalgets arbejde: $\gg I$ væsentlige punkter, navnlig vedr. kirkeforfatningen, sympatiserede I.C. Christensen med IM og lagde ikke skjul derpå - skønt hans hjem var i den grundtvigske lejr." CP's arkiv. Til udvalget valgtes 3 præster og 5 lægfolk fra Nordslesvig: Præsterne Nissen, Tonnesen og CP (alle fra Haderslev provsti!) samt de læge Iversen, Tøstesen, Oluf Olesen, Jacobsen og C. Michaelsen.

Foruden forfatningsudvalget var $\mathrm{CP}$ bl.a. medlem af underudvalgene om menighedsråd, kirkesproget, bispeog provstevalg og om gudstjenesten. I øvrigt forsøgte han sig med et forslag om at indføre personregistre som i Sønderjylland, med regel om at præster ikke burde føre disse.

1.7.1922 trådte de nye kirkelove i kraft.

71. Jørgen Nissen (1861-1923), f. i Gl. Haderslev. Sognepræst i Brørup, provst i Malt 1899, sognepræst i Vemmelev 1910, provst i Haderslev Provsti og sognepræst i Gl. Haderslev 1920, kst.biskop for de sønderjyske landsdele maj 1922 ved Gabriel Kochs død. Forbehold i forhold til den grundtvigske invasion i Nordslesvig stod CP ikke alene med. Den unge morsingbo Filtenborg i Fole skriver 1925 til CP: »det er meget sjældent at træffe en sønderjyde, som har noget begreb om, hvad kirkelig grundtvigianisme er. Og jeg vil endogså mene, at grundtvigiansk farvet kristendom ... ikke passer for den sønderjydske folkekarakter ..."

72. Brev fra Nissen 24.1.1921 med den karakteristiske formulering »der er blevet udtalt ønske om « - formentlig fra Nissen selv.

73. Oluf Olesen, fremtrædende lægmand fra Døstrup, aktiv i ydre mission, repræsenterede fra 1920 det nordslesvigske Jeypore-arbejde i det danske missionsselskab DMS. Formand for det kortvarige kostskoleinitiativ i Løgumgård.

74. Kirkehistorikeren Hans Hejselbjerg Paulsen (1905-78), sognepræst i 
Skrydstrup og Fjelstrup, dr.theol. på H.A. Brorson, deler meget markant $\mathrm{CP}^{\prime}$ 's vurdering af manøvrerne omkring Genforeningen, se Paulsen 1948, s.10: »der var i hvert fald én mand i Nordslesvig, sognepræst CP i Magstrup, som klart saa faren, og som ufortrødent rejste forfatningsspørgsmålet i pressen. "Men »selve forfatningsspørgsmaalet blev $\mathrm{i}$ al stilhed afgjort mellem regeringen i København og Den nordslesvigske Vælgerforening «. Også kirkehistorikeren P. Severinsen søgte at undgå, at den nordslesvigske kirke blev »trukket i dansk kirkeforfatningsuniform «.

75. Frederik Torm, (1870-1953), professor i Ny Testamente 1903, formand for Den danske Israelsmission.

76. Harald Westergaard (1853-1936), professor i statsvidenskab 1886-1924, rektor for universitetet 1914-15, i bestyrelsen for IM i København og medinitiativtager til Københavns Kirkefond 1896.

77. Johannes Oskar Andersen (18661959), professor i kirkehistorie 191336, rektor for universitetet 1929-30, folketingsmedlem 1918-39, medlem af Rigsdagens sønderjyske udvalg 1919-20.

78. Direkte indflydelse i den nordslesvigske kirke fik ministeriets kursus for præsterne fra landsdelen, afholdt med et tæt program på lærerhøjskolen i Odensegade 2.-21. september. Her medvirkede primært Henry Ussing, Olfert Ricard, Valdemar Ammundsen (endnu professor) og J. Oskar Andersen.

79. Hjalmar Hammershaimb (18561923), overretssagfører og forsikringsdirektør.

80. Provstiudvalgene endte med at blive Sønderjyllands varige bidrag til folkekirkens »styringsstruktur «.

81. Johannes Gøtzsche (1866-1938), søn af biskop i Ribe, sognepræst og provst i Herning 1900, kst. provst i Rødding 1920, biskop i Viborg 1921.

82. Christen Christensen Hjortkjær (1869-1944), sognepræst i Hjortlund 1898 og provst i Malt 1902, sognepræst Kgs. Lyngby 1913, i Sommer- sted 1921 og i Gl. Haderslev 1923, samme år stiftsprovst i Haderslev.

83. Axel Emil Bülow (1862-1952), sognepræst i Marstal 1916-27, g.m. Nicoline Hansen, datter af kniplingskræmmer Detlef Hansen i Møgeltønder.

84. Christian Michaelsen, Kastvrå, tidligere medlem af provstisynoden.

85. Ved lov bestemtes, at menighederne skulle stemme om sognepræstens forbliven eller nyvalg, hvis menigheden »skønner, at sognepræstens forbliven i embedet på afgørende måde vil virke til skade for det kristelige livs fremvækst i sognet «. Ved hovedparten af afstemningerne blev sognepræsterne overraskende bekræftet i deres embede.

Blandt de nye præster nordfra, der nu dukkede op, fik CP et særligt forhold til Th. Aaholm (1889-1965) i Vojens 1923-55. Aaholm støtter sig til CP ved mange lejligheder omkring kirkelige begivenheder (indvielse af kirken 1925, mindesten 1927 og kirkegårdsudvidelse 1935). Begge er de nærmest knyttet til IM (som deres biskopper Ammundsen og Noack), og trives med at udveksle tanker om liturgi, salmer og nordiske forhold; begge var meget optaget af at oversætte og bearbejde nordiske salmer til brug i danske kirker i stedet for den ensidige tyske tradition. Vinteren 1940 skriver de om truslen fra syd, stiftsprovstevalget $\mathrm{i}$ Haderslev og den nye ungdomsskole i Vojens vest.

86. Valdemar Ammundsen (1875-1936), professor i kirkehistorie 1901, biskop i Haderslev 1923-36. Internationalt kendt, både som fagteolog og kirkemand, i særlig grad Genforeningens biskop i Sønderjylland, med levende kontakt til den tyske evangeliske kirkelighed. Stemmetal ved bispevalget: Ammundsen 655, Hjortkjær 429.

87. CP undlader at skrive nærmere om sin interesse for kirkebygning og kirkekunst, udtrykt i hans artikler om kirkerne i Nordslesvig. I 1906 deltager han i den 2. kongres for »Kirchenbau« $\mathrm{i}$ Dresden og skriver om det $\mathrm{i}$ 
Kirchen- und Schulblatt: »Protestantischer Kirchenbau«, 1906, s. 511-17. Endvidere i samme blad en beskrivelse af »Der Dom von Schleswig", 1909, s. 11-15, 126-30. Til det sidste bevarede han tvivlen, om han skulle have været noget med byggeri.

88. Rejserne fylder forbavsende lidt i hans erindringer $i$ betragtning af det store antal efterfølgende breve og hilsener i hans arkiv fra de forskellige konferencer. Hvilket vidner om, at $\mathrm{CP}$ har bevaret sin evne til at skabe kontakt uden for den hjemlige ramme. Allerede i 1913, 11.-15. juni, deltog han i KFUM's Verdenskonference i Edinburgh; undervejs besøgte han London. 1930 rejste han til Holland og Belgien, tilsyneladende $i$ bil. Væsentlig var hans deltagelse i det nordiske studentermøde i Trondheim 1924, hvor han træffer danske teologer som Eduard Geismar, Hans Koch, N.I. Heje, Tage Schack, Harald Sandbæk, Kaj Thaning og Bodil Koch samt nationaløkonomen, senere universitetsrektor Carl Iversen og nabopræsten i Vojens Th. Aaholm. CP deltog igen i studentermødet 1929, nu i Örebro.

Om fædrelandet kan tilføjes, at CP i det mindste foretog en biltur i egen vogn til Skagen 1933 iflg. brev fra svenske venner 15.9. Af et brev fra Kai Larsen i 1929 kan vi se, at allerede da var $\mathrm{CP}$ bilejer.

89. Mit Land, 1919 , en digtsamling med motiver fra Sønderjyllands landskab og historie til verdenskrigens slut, iflettet personlige minder, $142 \mathrm{~s}$. 1921 meddeler Fergos forlag, at der er 500 stk. tilbage (CP's arkiv).

90. Peder J. Wandal. Et Præsteliv $i$ det syttende Aarhundrede, 1924, $131 \mathrm{~s}$.

91. Lidt summarisk udtrykt. I 1921 virker CP som formidler af prædikanter for Københavns Kirkefond Store Bededag i en række sønderjyske kirker. Med Harald Westergaard lige over for sig i kirkeudvalget havde han nok svært ved at undslå sig. I øvrigt gik den sønderjyske støtte til byggeriet af Timoteus-kirken i Valby.

Ved et præstekonvent på Nyborg
Strand 1923 taler CP om »Vidnesbyrdet i forkyndelsen «, trykt i Præsteforeningens Blad, 1923, s. 281-85, og i Dansk Kirkeliv, 1925, s. 45-64, finder vi artiklen »Efter fem år. Fra kirkelivet i Sønderjylland «, som i øvrigt er baseret på en rundspørge til en række pastorater. Samme år afviser han at bidrage til Tonnesen Nordslesvigsk Kirkeliv, hvor han fik emnet »Kristendom og folkelighed « tilbudt. Endvidere afviser han mere forståeligt $\mathrm{i}$ 1932 at skrive til H.P. Hanssen-festskriftet. Endelig fik også Svend Thorsen et nej, da han anmoder om bidrag til en bog om de "psykologiske sider af genforeningsprocessen «. Da afslaget »bedrøver ham «, prøver han endnu en gang (breve 10.4.1937 og 20.6.1937).

92. Ridderkorset tildeltes ham 1924. Ikke uden sammenhæng hermed inviteres $\mathrm{CP}$ til taffel og musikprogram på kongeskibet Dannebrog i Haderslev havn 15.6.1928; invitation 14.6. (Haarløv).

93. Igen nok lidt summarisk. CP's arkiv vidner i hvert fald om mødeaftaler $i$ det sønderjyske, f.eks. det velbesøgte lederkursus på Hoptrup Højskole 1928, hvor han medvirkede sammen med Ammundsen, den senere biskop Noack fra Flensborg og pastor T. Biering, Sønderborg (fra 1931 i Dybbøl).

94. 1920 og 1926, se Holdt 1961, s. 61.

95. Det må siges at være gådefuldt, hvorfor CP taler om Stubbæk. Personregisteret fortæller ikke noget herom; det kan have været en kortere tid, inden han slår sig ned i Stentoft på Løjt Land, tæt ved fjorden, hvor han havde sejlbåd liggende. Fra Stentoft flytter han 31.7.1935 til Forstallé 12 i Aabenraa. Meddelt af Landsarkivet.

Bopælen i Stentoft bekræftes af brev af 14.12.1931 fra Hans Knudsen, tidl. indremissionær: "jeg kan slet ikke få det til at passe ... Skal De da virkelig sidde og dø i Stentofte? Måske mens De sidder og blader i arkivets gulnede blade? Nej ... jeg kunne tænke mig, at De døde midt i brændingen, mens skumsprøjt 
stod til alle sider ...«. Vemodigt, skriver Knudsen, og mindes datteren Annes gode ophold i Magstrup præstegård 1927. CP korresponderede med Anne, mens hun var i København, og holdt i det hele taget god forbindelse med de unge på deres videre færd. Breve fra Anne Knudsen og Marie Schultz, Skt. Lukassøster, i CP's arkiv.

96. Slesvigske Præster. Et Udsnit af Præstestandens Historie, 1938, 369 s. En del taknemlige reaktioner fra præster $\mathrm{i}$ landsdelen i arkivet, bl.a. fra dem, der ikke har været hjemme, da CP ankom i sin bil for at aflevere. Og fra det øvrige Danmark: Fuglsang-Damgaard (Københavns biskop), selv sønderjyde, Fr. Schrøder, Holbæk, tidl. Fjelstrup, Chr. Bartholdy, IM's formand, fhv.departementschef V. Holbøll og den katolske biskop Suhr. Fra Haderslev Katedralskole takker rektor Egeberg Jensen. Og fra Uge præstegård takker den unge sognepræst Chr. Jessen for et eksemplar til den tyske frimenighedspræst Friedrich Jessen.

97. Trykt i Sønderjyske Årbøger. 1931: »Landsbykirkerne i Haderslev Provsti efter Reformationen «; 1939: »Kirker i Tørninglen Provsti« (belønnet med Dansk Historisk Fællesforenings pris, se Sønderjyske Arbøger 1941, s. 169); 1941: »Kirker i Tønder Provsti« , og 1942: »Kirker i Sønderborg Provsti «. Artiklerne fra 1931 til 1941 er udgivet samlet i særtryk un- der titlen Slesvigske Landsbykirker gennem 300 Aar, 1941. Omfattende korrespondance med præster i den anledning, f.eks. med den grundige pastor Filtenborg i Fole, der 1943 sender det sidste brev kort før CP's død. Endvidere »Søren Kierkegaard og Nordslesvig « i Sønderjyske Arbøger 1933. Endelig posthumt udgivet "Slesvigske Præstegårde «i Sønderjyske Årbøger 1946.

To salmer af $\mathrm{CP}$ blev medtaget $\mathrm{i}$ det sønderjydske salmebogsforslag 1943, nr. 668 »Sænk din Fred « (skrevet til indvielsen af Vojens kirkegård 1936) og nr. 913 »Da Moses gik alene op «; korrespondance m. Anders Malling i $\mathrm{CP}^{\prime}$ s arkiv.

Manus slutter lidt brat, CP var trods alt beskæftiget og i dialog til det sidste. 28.1.1943 har han lovet et konventsforedrag i Ullerup præstegård, aftalt med pastor Warncke: "Skal der forkyndes et dansk evangelium i Sønderjylland? « Allerede i 1942 betegner han sig selv som »færdig «, brev til Aaholm 13.2.

CP forfattede selv sin dødsannonce: »Præsten Carsten Petersen samledes i dag til sit folk. Han sender sine venner en sidste hilsen med tak for følge. Joh.Aab. 4«. Efter hans bestemmelse blev der begravelse uden kranse, uden præstetale, kun med læsningen fra Åbenbaringsbogen ved et familiemedlem, bøn og en salme.

\section{Zusammenfassung}

Carsten Petersen (1871-1943) war ein Pastor, der sowohl vor als auch nach der Volksabstimmung 1920 tätig war, wo Schleswig in einen dänischen und einen deutschen Bereich geteilt wurde. Seine Ausbildung war deutsch, seine Bildung und sein kultureller Horizont jedoch tragen Spuren beider Länder. Über seine nationale Gesinnung als dänischer Nordschleswiger herrschte kein Zweifel. Nach seinem Abitur in Hadersleben studierte er in Kiel, Erlangen und Berlin. Theologisch war er konservativ mit Verbindungen zur Inneren Mission in Nordschleswig und in der Zeit als Pastor am kirchlichen Wochenblatt 
Kirchen- und Schulblatt tätig. Sein erstes Amt lag in Flensburg bei der dänischen Minderheit an der »Helligåndskirche «, danach in Braderup südlich von Tondern. 1911 kehrte Petersen nach Nordschleswig zurück als Pastor in Magstrup-Jegerup bei Hadersleben. In der Zeit nach dem Weltkrieg spielte er eine entscheidende Rolle in Verbindung mit den Verhandlungen über die Integration der nordschleswigschen Kirche in die dänische Volkskirche. Seiner Auffassung nach wurden die schleswigschen Erfahrungen aus dem Kirchenleben und nicht zumindest aus der Selbstverwaltung der Kirche arrogant zu Gunsten des Dänischen beiseitegeschoben, was er als Mitglied der Kirchenkommission der dänischen Regierung 1921 zum Ausdruck brachte. Petersen fühlte sich teilweise ignoriert, seine Vergangenheit als Pastor in der deutschen Staatskirche war für ihn nicht von Vorteil, obwohl er ein erhebliches Wissen über die lutherisch-kirchliche Entwicklung auch auf europäischer Ebene mit sich brachte. Nach seinem Rücktritt 1932 konzentrierte er sich auf historische Studien und veröffentlichte 1938 das bedeutende Sammelwerk Slesvigske Præster sowie kleinere Abhandlungen über Kirchen und Gemeinden in Nordschleswig. Petersen schrieb auf seine eigene Art, original aber oft unsystematisch und blieb seiner eigenen Person als Mensch aus dem Grenzgebiet treu. 